Nevada

Environmental

Restoration

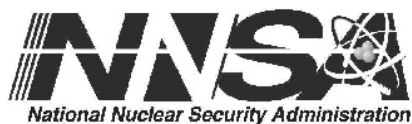

Project

Closure Report for the 92-Acre Area and Corrective Action Unit 111: Area 5 WMD Retired Mixed Waste Pits, Nevada National Security Site, Nevada

Controlled Copy No::

Revision: 0

February 2012

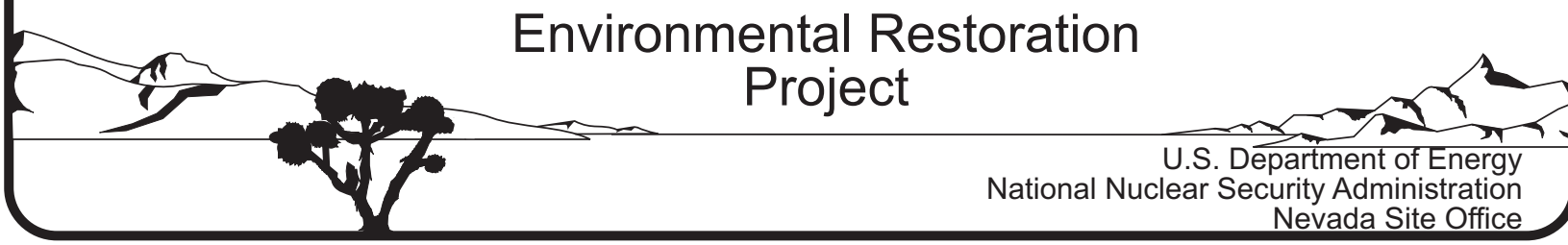




\section{DISCLAIMER}

Reference herein to any specific commercial product, process, or service by trade name, trademark, manufacturer, or otherwise, does not necessarily constitute or imply its endorsement, recommendation, or favoring by the United States Government or any agency thereof.

This report has been reproduced directly from the best available copy.

Available for sale to the public from:

U.S. Department of Commerce

National Technical Information Service

5301 Shawnee Road

Alexandria, VA 22312

Telephone: (800) 553-6847

Fax: (703) 605-6900

E-mail: orders@ntis.gov

Online ordering: http://www.ntis.gov/help/ordermethods.aspx

Available electronically at http://www.osti.gov/bridge.

Available for a processing fee to the U.S. Department of Energy and its contractors, in paper, from:

U.S. Department of Energy

Office of Scientific and Technical Information

P.O. Box 62

Oak Ridge, TN 37831-0062

Telephone: (865) 576-8401

Fax: (865) 576-5728

E-mail: reports@adonis.osti.gov 


\title{
CLOSURE REPORT FOR THE 92-ACRE AREA AND CORRECTIVE ACTION UNIT 111: AREA 5 WMD RETIRED MIXED WASTE PITS, NEVADA NATIONAL SECURITY SITE, NEVADA
}

\author{
U.S. Department of Energy \\ National Nuclear Security Administration \\ Nevada Site Office \\ Las Vegas, Nevada
}

Controlled Copy No.

Revision: 0

February 2012 
THIS PAGE INTENTIONALLY LEFT BLANK 


\section{CLOSURE REPORT FOR THE 92-ACRE AREA AND CORRECTIVE ACTION UNIT 111: AREA 5 WMD RETIRED MIXED WASTE PITS, NEVADA NATIONAL SECURITY SITE, NEVADA}

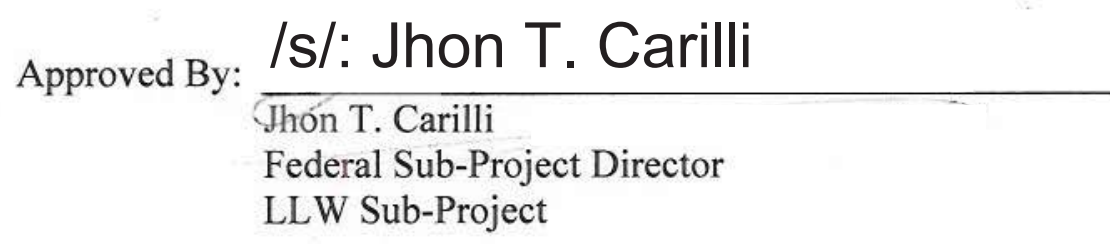

Date: $2 / 2 / 20,2$

Approved By: /s/: Scott Wade

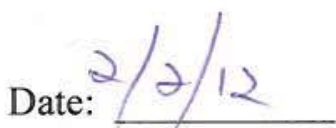

Deputy Assistant Manager

Environmental Management 
THIS PAGE INTENTIONALLY LEFT BLANK 


\section{TABLE OF CONTENTS}

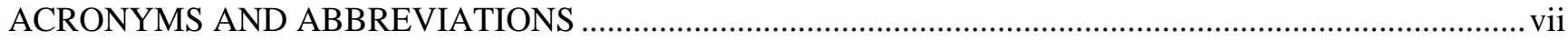

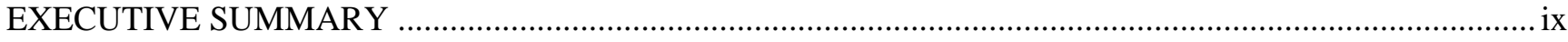

1.0 INTRODUCTION

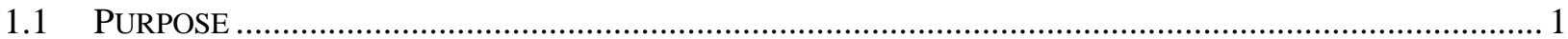

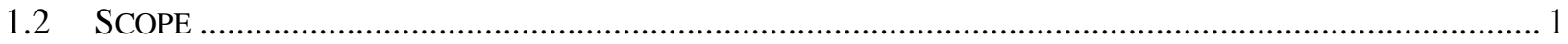

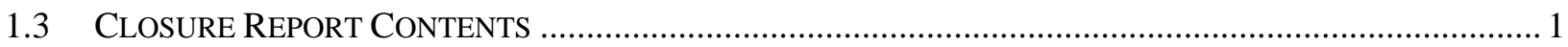

1.3.1 Applicable Programmatic Plans and Documents ............................................................. 4

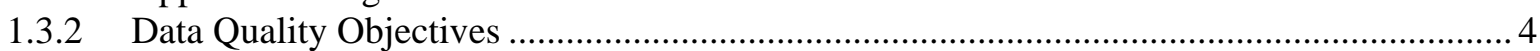

1.3.3 Data Quality Assessment........................................................................................ 4

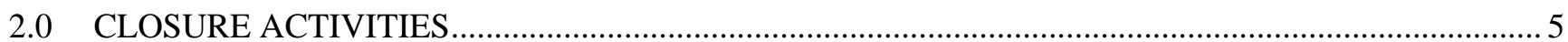

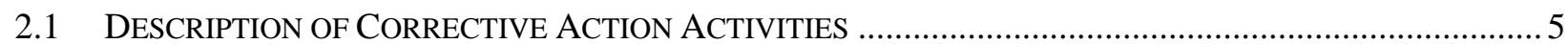

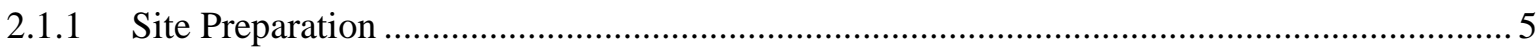

2.1.2 Engineered Cover Construction ............................................................................... 5

2.1.3 Temporary Erosion and Sediment Control and Planting Vegetation ................................. 6

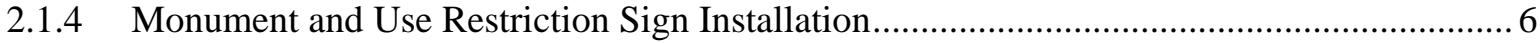

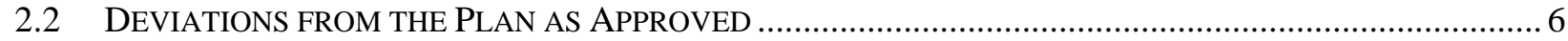

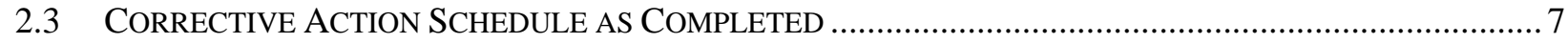

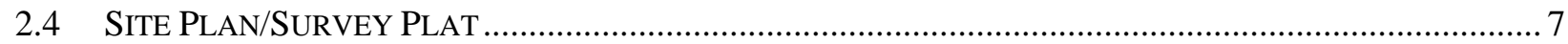

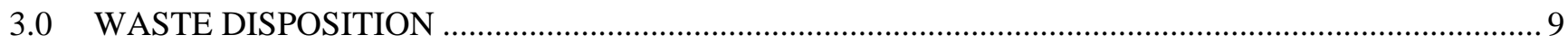

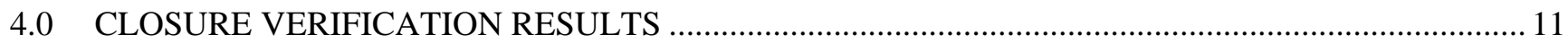

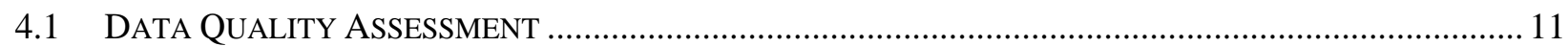

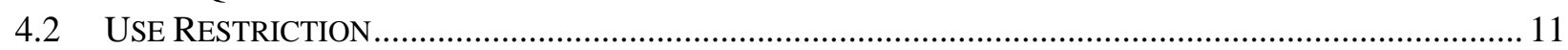

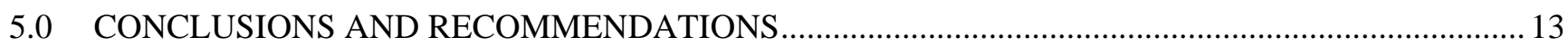

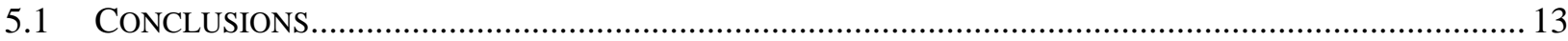

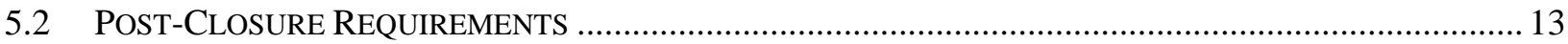

5.2.1 Inspections, Surveys, and Maintenance and Repair .................................................... 13

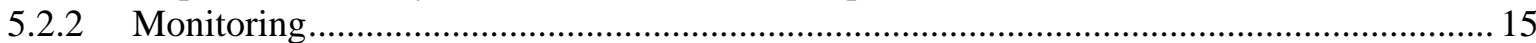

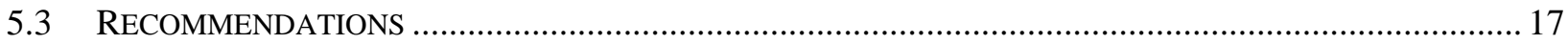

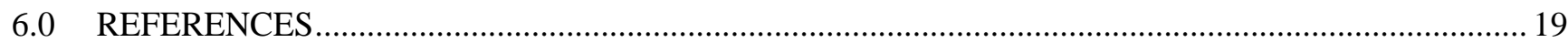

LIBRARY DISTRIBUTION LIST

\section{LIST OF FIGURES}

Figure 1. Area 5 Radioactive Waste Management Site Location Map ......................................2

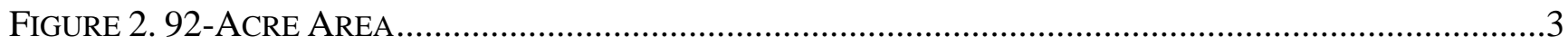

\section{LIST OF TABLES}

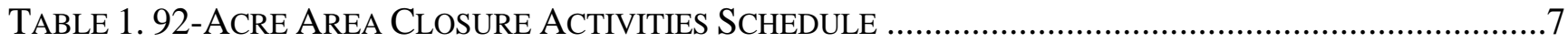

TABle 2. Post-Closure ReQuirements ANd Compliance Criteria FOR THE 92-ACre AreA ..........14

TABle 3. CoMPliANCE CRITERIA fOR Air MONITORING .............................................................15 
Section: Table of Contents

Date: February 2012

\section{TABLE OF CONTENTS (continued)}

TABLE 4. LIMITATIONS FOR GROUNDWATER INDICATOR PARAMETERS …...........................................15

Table 5. Progressive Approach for VAdose Zone Monitoring for the 92-ACre AreA .............16

\section{APPENDICES}

Appendix A. Data Quality ObJectives

ApPEndix B. As-Built DoCUMENTATION AND ClOSURE CERTIFICATION

APPENDIX C. USE RESTRICTION DOCUMENTATION

ApPENDiX D. Site Closure PhOTOGRAPHS 


\section{ACRONYMS AND ABBREVIATIONS}

CADD/CAP

CAU

CFR

CQA

CR

DQO

FFACO

$\mu \mathrm{g} / \mathrm{L}$

$\mathrm{mg} / \mathrm{L}$

mmhos/cm

NDEP

NNSA/NSO

$\mathrm{pCi} / \mathrm{L}$

$\mathrm{pCi} / \mathrm{m}^{2} \mathrm{~s}$

$\mathrm{pCi} / \mathrm{m}^{3}$

RCRA

TDR

TLD

UR
Corrective Action Decision Document/Corrective Action Plan

Corrective Action Unit

Code of Federal Regulations

construction quality assurance

Closure Report

data quality objective

Federal Facility Agreement and Consent Order

microgram(s) per liter

milligram(s) per liter

millimho(s) per centimeter

Nevada Division of Environmental Protection

U.S. Department of Energy, National Nuclear Security Administration Nevada Site Office

picocurie(s) per liter

picocurie(s) per square meter per second

picocurie(s) per cubic meter

Resource Conservation and Recovery Act

time-domain reflectometry

thermoluminescent dosimeter

use restriction 
92-Acre Area and CAU 111

Closure Report

Section: Acronyms and Abbreviations

Revision: 0

Date: February 2012

THIS PAGE INTENTIONALLY LEFT BLANK 


\section{EXECUTIVE SUMMARY}

This Closure Report (CR) presents information supporting closure of the 92-Acre Area, which includes Corrective Action Unit (CAU) 111, “Area 5 WMD Retired Mixed Waste Pits.” This CR provides documentation supporting the completed corrective actions and confirmation that the closure objectives were met. This CR complies with the requirements of the Federal Facility Agreement and Consent Order (FFACO) (FFACO, 1996 [as amended March 2010]).

Closure activities began in January 2011 and were completed in January 2012. Closure activities were conducted according to Revision 1 of the Corrective Action Decision Document/Corrective Action Plan (CADD/CAP) for the 92-Acre Area and CAU 111 (U.S. Department of Energy, National Nuclear Security Administration Nevada Site Office [NNSA/NSO], 2010).

The following closure activities were performed:

- Construct an engineered evapotranspiration cover over the boreholes, trenches, and pits in the 92-Acre Area.

- Install use restriction (UR) warning signs, concrete monuments, and subsidence survey monuments.

- Establish vegetation on the covers.

UR documentation is included as Appendix $\mathrm{C}$ of this report. The post-closure plan is presented in detail in Revision 1 of the CADD/CAP for the 92-Acre Area and CAU 111, and the requirements are summarized in Section 5.2 of this document. When the next request for modification of Resource Conservation and Recovery Act Permit NEV HW0101 is submitted to the Nevada Division of Environmental Protection (NDEP), the requirements for post-closure monitoring of the 92-Acre Area will be included.

NNSA/NSO requests the following:

- A Notice of Completion from NDEP to NNSA/NSO for closure of CAU 111

- The transfer of CAU 111 from Appendix III to Appendix IV, Closed Corrective Action Units, of the FFACO 
92-Acre Area and CAU 111

Closure Report

Section: Executive Summary

Revision: 0

Date: February 2012

THIS PAGE INTENTIONALLY LEFT BLANK 


\subsection{INTRODUCTION}

This Closure Report (CR) was prepared for the 92-Acre Area according to the Federal Facility Agreement and Consent Order (FFACO) (FFACO, 1996 [as amended March 2010]). The 92-Acre Area constitutes the southeast quadrant of the Radioactive Waste Management Site, located in Area 5 of the Nevada National Security Site, and includes Corrective Action Unit (CAU) 111, “Area 5 WMD Retired Mixed Waste Pits” (Figures 1 and 2).

\subsection{Purpose}

This CR provides justification for closure of the 92-Acre Area without further corrective action based on implementation of corrective actions in accordance with Revision 1 of the Corrective Action Decision Document/Corrective Action Plan (CADD/CAP) (U.S. Department of Energy, National Nuclear Security Administration Nevada Site Office [NNSA/NSO], 2010). The $\mathrm{CADD} / \mathrm{CAP}$ evaluates potential corrective actions, provides rationale for the selection of the recommended corrective action, presents the scope of work, and details the post-closure plan. Revision 1 of the CADD/CAP incorporates the revised cover design as presented in Design of Revisions to the Evapotranspiration Cover for the 92-Acre Area (CH2M HILL, 2010a). This CR provides a summary of completed closure activities, documentation supporting the completed corrective actions, and confirmation that the closure objectives were met.

\subsection{SCOPE}

The scope of closure for the 92-Acre Area included the following activities:

- Construct an engineered evapotranspiration cover.

- Install use restriction (UR) warning signs, monuments, and subsidence monuments.

- Establish vegetation on the covers.

\subsection{Closure Report Contents}

This CR includes the following sections:

- Section 1.0: Introduction

- Section 2.0: Closure Activities

- Section 3.0: Waste Disposition

- Section 4.0: Closure Verification Results

- Section 5.0: Conclusions and Recommendations

- Section 6.0: References

- Appendix A: Data Quality Objectives

- Appendix B: As-Built Documentation and Closure Certification

- Appendix C: Use Restriction Documentation

- Appendix D: Site Closure Photographs

- Library Distribution List 
Date: February 2012

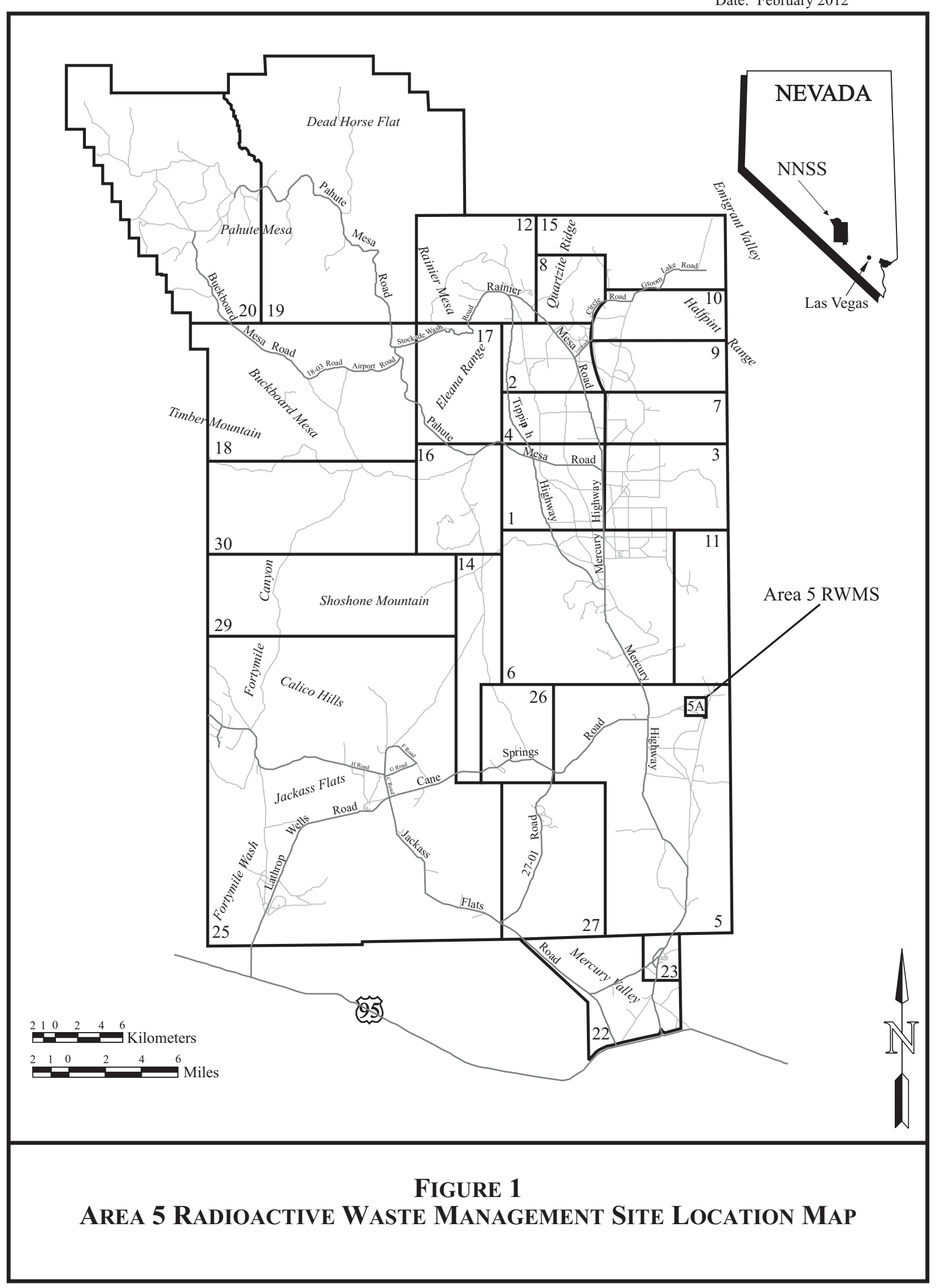


Date: February 2012

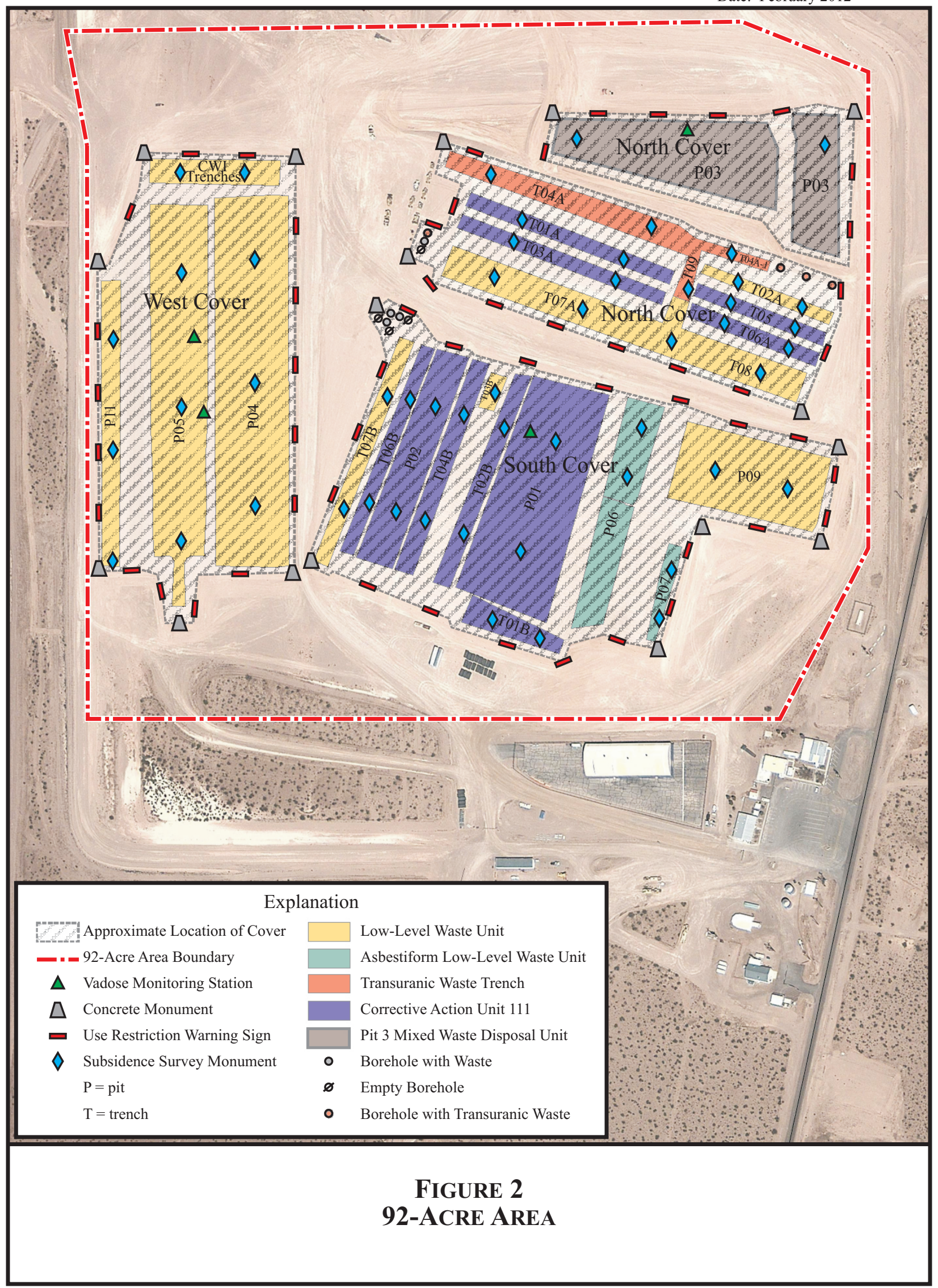




\subsubsection{Applicable Programmatic Plans and Documents}

Closure activities were performed in accordance with the following documents:

- Revision 1 of the CADD/CAP for the 92-Acre Area and CAU 111 (NNSA/NSO, 2010)

- FFACO (1996, as amended March 2010)

- Design of Revisions to the Evapotranspiration Cover for the 92-Acre Area (CH2M HILL, 2010a)

- Construction Quality Assurance Plan for 92-Acre Area Evapotranspiration Cover (CH2M HILL, 2010b)

\subsubsection{Data Quality Objectives}

Data quality objectives (DQOs) were developed for the 92-Acre Area in Revision 1 of the CADD/CAP (NNSA/NSO, 2010) and are included as Appendix A of this report. The DQOs were developed to evaluate available information about physical, chemical, hydrological, plant, animal, and climate characteristics, as well as facility design, operation, and source materials to develop a conceptual site model for the fate and transport of the waste inventory. Available information provided the input data necessary to evaluate closure options without the collection of additional data.

\subsubsection{Data Quality Assessment}

The data quality assessment is presented in Section 4.1. Construction samples were collected according to the approved construction quality assurance (CQA) plan (CH2M HILL, 2010b), and laboratory reports are presented in the interim and final CQA reports (Delphi Groupe, 2011; Delphi Groupe, 2012). The CQA Plan describes the specific field and laboratory testing and monitoring procedures required to demonstrate that the cover is constructed in accordance with the requirements of the design. The data collected met the requirements of the CQA Plan. 


\subsection{CLOSURE ACTIVITIES}

This section summarizes the closure activities completed for the 92-Acre Area, deviations from the CADD/CAP, the schedule of completed field work, and the final site plan.

\subsection{Description of Corrective ACTiOn ACtivities}

The 92-Acre Area was closed in place with administrative controls by constructing an engineered evapotranspiration cover according to the engineering drawings and specifications provided in Revision 1 of the CADD/CAP (NNSA/NSO, 2010). The following sections describe the closure activities completed for the 92-Acre Area.

\subsubsection{Site Preparation}

The site was cleared and grubbed prior to cover construction. Existing ancillary structures, including fencing, gates, signage, electrical panels, monitoring devices, and junction boxes, except as noted in the engineering design, were removed. The Greater Confinement Disposal boreholes were backfilled. Existing underground water, sewer, and communication lines were left in place. Underground power lines were abandoned in place.

\subsubsection{Engineered Cover Construction}

A 2.5-meter-thick engineered cover was installed over the boreholes, trenches, and pits in the 92-Acre Area. The cover consists of three smaller covers separated by drainage channels and/or roads. The three covers are designated as the North Cover, South Cover, and West Cover. The North Cover is separated into two portions by a drainage channel. Drainage ditches were constructed in accordance with the engineering design. Storm water runoff and erosion control features, including geotextile and 6-inch cobble in the drainage that crosses the road (Arizona crossing) to the northwest of the site, were installed. The maximum side slope of the covers is 3:1. With the exception of two open pits (P03 and P06), all trenches and pits in the 92-Acre Area had operational covers approximately 2.4 meters thick; therefore, construction of the covers over these units consisted of augmenting the operational covers to the final thickness, grade, compaction, and slope required by the engineering design.

After the open pits were backfilled to grade, the cover was placed in 18-inch lifts that were ripped to between 75 and 85 percent relative compaction in accordance with the engineering design. Heavy equipment used to perform final grading was equipped with a global positioning system to ensure accurate grade elevations. When the top lift of the cover met the lines, grades, and dimensions required by the engineering design, the surface was ripped, and rocks larger than 9 inches in diameter and visible on the surface of the cover were removed. The surface was then track walked to smooth the surface of the cover for application of the interim soil stabilizer before vegetation activities were conducted in the cooler fall and winter planting season.

During cover construction, CQA activities were performed by an independent CQA team led by a Nevada Licensed Professional Engineer. The CQA team performed CQA activities in accordance with the CQA Plan and certified that closure met the design requirements. CQA activities included collecting field and laboratory tests, monitoring construction activities, and 
performing an as-built survey. Laboratory samples for moisture/density and in situ field samples for soil classification, moisture, and density were collected according to the approved CQA Plan (CH2M HILL, 2010b). The density and moisture contents were within the specified relative compaction and moisture content requirements of the design.

Corrective actions were confirmed by visual inspection and photographic documentation of the final site conditions, and the cover was as-built surveyed. The final survey plat was prepared and certified by a professional land surveyor and is included in Appendix B of this report. In addition, a registered professional engineer signed a certification of closure that states that the site has been closed in accordance with the specifications of the plan. The certification of closure is also included in Appendix B of this report.

More detailed information on cover construction is presented in the interim and final CQA reports. The CQA reports present a detailed description of construction activities and include the CQA daily reports, CQA laboratory summary and test reports, a CQA in-place moisture density test summary, a soil stabilization performance report and product information, Requests for Information and Engineering Change Notices, the as-built drawing, and verification that vegetation activities met the design specifications (Delphi Groupe, 2011; Delphi Groupe, 2012).

\subsubsection{Temporary Erosion and Sediment Control and Planting Vegetation}

A soil stabilizer was applied to the covers between completion of grading activities and initiation of vegetation seeding to provide temporary erosion and sediment control. The soil binder product was applied to the surface of the final covers by a truck-mounted boom spray and hoses and was intended to control erosion for a minimum of 6 months prior to seeding.

The top layer of soil was then disked to alleviate compaction and provide a suitable soil environment for seeding. The covers were then seeded with a mixture of native plant species. A straw mulch was spread and crimped into the soil after seeding to protect the covers from erosion and conserve soil moisture. A solid-set irrigation system was installed to augment natural precipitation and provide optimal conditions for seed germination and plant establishment.

\subsubsection{Monument and Use Restriction Sign Installation}

A total of 52 subsidence survey monuments were installed on the covers. Each monument consists of a 12-inch square plate fitted with a small riser and brass cap. Each square plate was placed within the cover, and the brass cap protrudes into a 6-inch-diameter frame and lid to provide access for surveyors. The top of the frame and lid is set at the top of the grade.

Concrete monuments were installed along the edges of the covers, and UR warning signs measuring 1 foot by 1 foot were attached to the monuments. Larger UR warning signs measuring 2 feet by 3 feet were installed at intervals of approximately 200 feet around the perimeters of the three covers to delineate the UR according to the FFACO Use Restriction Posting Guidance (FFACO, 2003).

\subsection{Deviations from the Plan as Approved}

Deviations from Revision 1 of the CADD/CAP (NNSA/NSO, 2010) were not required. 


\subsection{Corrective Action Schedule as Completed}

Closure activities began in January 2011 and were completed in January 2012. Details of the schedule are provided in Table 1.

Table 1. 92-Acre Area Closure Activities Schedule

\begin{tabular}{||l|c|c||}
\hline \multicolumn{1}{|c|}{ ACTIVITY } & START & END \\
\hline \hline Engineered Cover Construction & January 20, 2011 & May 10, 2011 \\
\hline As-Built Survey & May 12, 2011 & May 12, 2011 \\
\hline Re-Vegetation & October 12, 2011 & December 15, 2011 \\
\hline Monument and Use Restriction Sign Installation & January 9, 2012 & January 29, 2012 \\
\hline
\end{tabular}

\subsection{Site Plan/Survey Plat}

The 92-Acre Area was closed in place with administrative controls (i.e., a UR was implemented). An engineered soil cover was installed, the cover was as-built surveyed, and the as-built drawing is included as Appendix B of this report. In addition, the corners of the use-restricted area were land surveyed, and a figure showing the locations of the surveyed points delineating the UR area, in addition to the Use Restriction Information form, is included in Appendix C of this report. 
92-Acre Area and CAU 111

Closure Report

Section: Closure Activities

Revision: 0

Date: February 2012

THIS PAGE INTENTIONALLY LEFT BLANK 
92-Acre Area and CAU 111

Closure Report

Section: Waste Disposition

Revision: 0

Date: February 2012

\subsection{WASTE DISPOSITION}

No waste was generated during closure of the 92-Acre Area. 
92-Acre Area and CAU 111

Closure Report

Section: Waste Disposition

Revision: 0

Date: February 2012

THIS PAGE INTENTIONALLY LEFT BLANK 


\subsection{CLOSURE VERIFICATION RESULTS}

Site closure was verified by visual inspection and photographic documentation of final site conditions, and the cover was as-built surveyed. The final survey plat was certified by a professional land surveyor and is included in Appendix B of this report. In addition, a certification of closure was signed by a registered professional engineer to confirm that the site had been closed in accordance with the specifications of the plan. The certification of closure is also included in Appendix B of this report. Photographs are included in Appendix D.

\subsection{Data Quality Assessment}

Construction samples, including in situ testing for soil classification, moisture, and density and laboratory analysis for moisture and density characteristics, were collected according to the approved CQA Plan. The quality assurance and quality control procedures for the 92-Acre Area can be found in the CQA Plan (CH2M HILL, 2010b). CQA activities were performed by an independent CQA team, led by a Nevada Licensed Professional Engineer. The CQA team lead was responsible for all CQA activities, and certified closure. The CQA team members, who report to the CQA team lead, performed field test, collected laboratory tests, archived samples, monitored construction activities, and performed the as-built survey. The interim and final CQA reports include the CQA laboratory reports (Delphi Groupe, 2011; Delphi Groupe, 2012).

\subsection{USE RESTRICTION}

An engineered soil cover was installed over the boreholes, trenches, and pits in the 92-Acre Area, and UR warning signs were posted to warn against intrusive activity according to the FFACO UR posting guidance (FFACO, 2003). The Use Restriction Information form and a figure showing the locations of the surveyed points delineating the UR area are included in Appendix $\mathrm{C}$ of this report. The post-closure plan is presented in detail in the approved CADD/CAP, and the requirements are summarized in Section 5.2 of this document. 
92-Acre Area and CAU 111

Closure Report

Section: Closure Verification

Revision: 0

Date: February 2012

THIS PAGE INTENTIONALLY LEFT BLANK 


\subsection{CONCLUSIONS AND RECOMMENDATIONS}

The 92-Acre Area has been closed in accordance with Revision 1 of the CADD/CAP (NNSA/NSO, 2010).

\subsection{CONCLUSIONS}

The following closure activities were performed at the 92-Acre Area as documented in this CR:

- An engineered evapotranspiration cover was constructed over the boreholes, trenches, and pits in the 92-Acre Area.

- UR warning signs, concrete monuments, and subsidence survey monuments were installed.

- The cover was seeded.

\subsection{Post-Closure ReQuirements}

The post-closure requirements for the 92-Acre Area, including inspection and monitoring activities, compliance criteria for each activity, and actions required if the compliance criteria are exceeded, are summarized in Table 2 and detailed in the following sections.

\subsubsection{Inspections, Surveys, and Maintenance and Repair}

Quarterly visual site inspections will be conducted to verify that the UR warning signs are in place and readable and that the UR has been maintained. The covers will be inspected for cracks, animal burrows, or other evidence of subsidence or erosion. In addition, non-scheduled inspections will be conducted if precipitation occurs in excess of 1.0 inch in a 24-hour period to verify the continued integrity of the covers and document any ponding or erosion.

The subsidence survey monuments will be land surveyed on an annual basis to determine if overall subsidence of the covers has occurred. In addition, an annual assessment will be conducted by an ecological specialist or biologist to evaluate the success of the establishment of vegetation on the covers and make recommendations for maintenance of the vegetation.

Any identified maintenance or repair requirements will be reported to the Nevada Division of Environmental Protection (NDEP) and completed within 60 calendar days of discovery. Repair work shall preserve the original "as-built" cover design. If the cover repair requires the modification of the cover design, NNSA/NSO shall present a formal design modification request to NDEP prior to making the design modification. All repair and maintenance activities will be documented in writing at the time of the repair.

The results of inspections, subsidence surveys, vegetation surveys, and repair and maintenance activities will be summarized in the annual combined post-closure report for closed Resource Conservation and Recovery Act (RCRA) CAUs. Copies of completed inspection checklists, field notes, and photographs taken during the inspections will be included in the report. 


\section{TABle 2. Post-Closure Requirements AND CoMPlince Criteria FOR THE 92-ACRE AREA}

\begin{tabular}{|c|c|c|}
\hline ACtivity & REQUIREMENT & COMPLIANCE CRITERIA AND ACTIONS \\
\hline $\begin{array}{l}\text { Visual } \\
\text { Inspections }\end{array}$ & $\begin{array}{l}\text { Quarterly visual site inspections for cracks, } \\
\text { animal burrows, subsidence, erosion, and UR } \\
\text { compliance } \\
\text { Additional inspections for ponding and erosion } \\
\text { after precipitation events in excess of } 1.0 \text { inch } \\
\text { in a 24-hour period }\end{array}$ & $\begin{array}{l}\text { Cracks or settling imperfections greater than } 15 \text { centimeters } \\
\text { deep that extend } 1.0 \text { meter or more (through animal burrows, } \\
\text { erosion, or subsidence) will be reported to NDEP within } \\
14 \text { days and repaired within } 60 \text { days of discovery. Damaged or } \\
\text { missing UR warning signs will be repaired or replaced within } \\
60 \text { days of discovery. Evidence of human intrusion into the } \\
\text { covers will be reported to NDEP immediately upon discovery. }\end{array}$ \\
\hline $\begin{array}{l}\text { Subsidence } \\
\text { Surveys }\end{array}$ & $\begin{array}{l}\text { Annual land surveys of subsidence survey } \\
\text { monuments }\end{array}$ & $\begin{array}{l}\text { Significant subsidence will be reported to NDEP within } 14 \text { days } \\
\text { and repaired within } 60 \text { days of discovery. }\end{array}$ \\
\hline $\begin{array}{l}\text { Vegetation } \\
\text { Surveys }\end{array}$ & $\begin{array}{l}\text { Annual survey by an ecological specialist or } \\
\text { biologist }\end{array}$ & $\begin{array}{l}\text { Recommendations made by the ecological specialist or biologist } \\
\text { will be implemented. }\end{array}$ \\
\hline $\begin{array}{l}\text { Direct } \\
\text { Radiation } \\
\text { Monitoring }\end{array}$ & Quarterly measurements from TLDs & $\begin{array}{l}\text { TLD exposure rate measurements greater than } 3 \text { times } \\
\text { background will be reported to NDEP within } 14 \text { days of } \\
\text { discovery. }\end{array}$ \\
\hline $\begin{array}{l}\text { Air } \\
\text { Monitoring }\end{array}$ & $\begin{array}{l}\text { Atmospheric moisture samples analyzed for } \\
\text { tritium every } 2 \text { weeks and air samples } \\
\text { submitted for laboratory analysis of } \\
\text { gamma-emitting and isotopic radionuclides } \\
\text { monthly }\end{array}$ & $\begin{array}{l}\text { Radionuclide concentrations in air that exceed the limits } \\
\text { identified in Table } 3 \text { will be reported to NDEP within } 14 \text { days } \\
\text { of discovery. }\end{array}$ \\
\hline $\begin{array}{l}\text { Radon Flux } \\
\text { Monitoring }\end{array}$ & Annual measurements of radon flux & $\begin{array}{l}\text { Radon fluxes that exceed the regulatory limit of } 20 \mathrm{pCi} / \mathrm{m}^{2} \mathrm{~s} \text { will } \\
\text { be reported to NDEP within } 14 \text { days of discovery. }\end{array}$ \\
\hline $\begin{array}{l}\text { Groundwater } \\
\text { Monitoring }\end{array}$ & $\begin{array}{l}\text { Water levels in three existing wells measured } \\
\text { quarterly and groundwater samples analyzed } \\
\text { for contamination indicators and water } \\
\text { chemistry parameters every } 6 \text { months }\end{array}$ & $\begin{array}{l}\text { Groundwater indicators of contamination that exceed the limits } \\
\text { listed in Table } 4 \text { or water chemistry parameters that exceed the } \\
\text { National Primary Drinking Water Standards (CFR, 2006a) will } \\
\text { be reported to NDEP within } 14 \text { days of discovery. }\end{array}$ \\
\hline $\begin{array}{l}\text { Meteorology } \\
\text { Monitoring }\end{array}$ & $\begin{array}{l}\text { Precipitation, air temperature, relative } \\
\text { humidity, wind speed and direction, and } \\
\text { barometric pressure recorded daily }\end{array}$ & $\begin{array}{l}\text { Visual inspections for ponding and erosion will be performed } \\
\text { on the next business day after the occurrence of precipitation } \\
\text { events in excess of } 1.0 \text { inch in a } 24 \text {-hour period. }\end{array}$ \\
\hline $\begin{array}{l}\text { Vadose Zone } \\
\text { Monitoring }\end{array}$ & $\begin{array}{l}\text { TDR probe and lysimeter data downloaded } \\
\text { quarterly }\end{array}$ & See Table 5. \\
\hline $\begin{array}{l}\text { Evaluation of } \\
\text { Monitoring } \\
\text { Program }\end{array}$ & $\begin{array}{l}\text { Monitoring program evaluated every } 5 \text { years to } \\
\text { determine whether the frequency and/or } \\
\text { approach should be modified }\end{array}$ & None \\
\hline
\end{tabular}

CFR: Code of Federal Regulations

NDEP: Nevada Division of Environmental Protection

$\mathrm{pCi} / \mathrm{m}^{2} \mathrm{~s}$ : picocurie(s) per square meter per second

TDR: time-domain reflectometry

TLD: thermoluminescent dosimeter

UR: use restriction 
Table 3. Compliance Criteria for Air Monitoring

\begin{tabular}{|c|c|}
\hline PARAMETER & LIMIT \\
\hline \hline Tritium & $25,000 \mathrm{pCi} / \mathrm{m}^{3}$ \\
\hline Americium-241 & $0.005 \mathrm{pCi} / \mathrm{m}^{3}$ \\
\hline Plutonium-238 & $0.0075 \mathrm{pCi} / \mathrm{m}^{3}$ \\
\hline Plutonium-239/240 & $0.005 \mathrm{pCi} / \mathrm{m}^{3}$ \\
\hline
\end{tabular}

$\mathrm{pCi} / \mathrm{m}^{3}$ : picocurie(s) per cubic meter

TABLE 4. Limitations FOR GROUNDWATER INDICATOR PARAMETERS

\begin{tabular}{|c|c|}
\hline PARAMETER & LIMIT \\
\hline \hline $\mathrm{pH}$ & Between 7.6 and 9.2 \\
\hline Specific Conductance & $<0.440 \mathrm{mmhos} / \mathrm{cm}$ \\
\hline Total Organic Carbon & $<1 \mathrm{mg} / \mathrm{L}$ \\
\hline Total Organic Halides & $<50 \mu \mathrm{g} / \mathrm{L}$ \\
\hline Tritium & $<2,000 \mathrm{pCi} / \mathrm{L}$ \\
\hline
\end{tabular}

mmhos/cm: millimho(s) per centimeter mg/L: milligram(s) per liter

$\mu \mathrm{g} / \mathrm{L}:$ microgram(s) per liter

pCi/L: picocurie(s) per liter

\subsubsection{Monitoring}

Monitoring requirements are summarized in Table 2 and include direct radiation monitoring, air monitoring, radon flux monitoring, groundwater monitoring, meteorology monitoring, and vadose zone monitoring. A progressive vadose zone monitoring approach, which begins with near-surface monitoring and progresses to deeper, more complex monitoring upon indication of potential contaminant migration or drastic changes in climatic conditions, will be implemented. Table 5 provides the specific details of the progressive monitoring approach for vadose zone monitoring. If a trigger condition for vadose zone monitoring, as identified in Table 5, is exceeded, vadose zone monitoring will progress to the next, more rigorous, monitoring step. Exceeding a trigger condition does not imply an out-of-compliance condition; rather, it indicates that expanded monitoring is required to ensure the continued protection of human health and the environment. The most current and acceptable technology for each progressive monitoring step is identified in Table 5; however, it is expected that as technology progresses over time, improved technology may be available at the time of implementation and will be used in lieu of those described in Table 5.

Results of monitoring will continue to be documented annually in the Nevada Test Site Waste Management Monitoring Report Area 3 and Area 5 Radioactive Waste Management Sites and in the Nevada Test Site Data Report: Groundwater Monitoring Program Area 5 Radioactive Waste Management Site. A copy of these reports will be included as an appendix to the annual combined post-closure report for closed RCRA CAUs. 
Table 5. Progressive Approach for Vadose Zone Monitoring for the 92-ACre Area

\begin{tabular}{|c|c|c|c|}
\hline $\begin{array}{c}\text { Progressive } \\
\text { Monitoring SteP }\end{array}$ & DESCRIPTION & $\begin{array}{l}\text { BASELINE/ACCEPTABLE } \\
\text { CONDITION }\end{array}$ & $\begin{array}{c}\text { Trigger Condition For } \\
\text { Progressing TO THE NEXT STEP }\end{array}$ \\
\hline Step 1: Base Monitoring & TDR and lysimeter monitoring & $\begin{array}{l}\text { No indication of contaminant } \\
\text { migration beneath the waste } \\
\text { zone }\end{array}$ & $\begin{array}{l}\text { Volumetric moisture content greater than } \\
30 \text { percent* for } 2 \text { consecutive years at the deepest } \\
\text { TDR probe location ( } 1.2 \text { meters beneath the floor } \\
\text { of Pit } 5 \text { ) }\end{array}$ \\
\hline $\begin{array}{l}\text { Step 2: Expanded Soil } \\
\text { Moisture Monitoring } \\
\text { Beneath the Waste Zone }\end{array}$ & $\begin{array}{l}\text { Drill borehole for neutron probe monitoring or } \\
\text { install TDR probes adjacent to waste cells to a } \\
\text { depth of } 3 \text { meters beneath the waste zone }\end{array}$ & $\begin{array}{l}\text { No indication of contaminant } \\
\text { migration beneath the waste } \\
\text { zone }\end{array}$ & $\begin{array}{l}\text { Volumetric moisture content greater than } \\
30 \text { percent* for } 2 \text { consecutive years at the deepest } \\
\text { probe location ( } 3 \text { meters beneath the waste zone) }\end{array}$ \\
\hline $\begin{array}{l}\text { Step 3: Soil Sampling } \\
\text { for Contaminants } \\
\text { Beneath the Waste Zone }\end{array}$ & $\begin{array}{l}\text { Collect soil samples at } 3 \text { meters below the } \\
\text { waste zone (e.g., geoprobe, core drill) near the } \\
\text { location(s) exceeding the trigger condition in } \\
\text { Step } 2 \text { and analyze for RCRA toxicity } \\
\text { characteristic contaminants (CFR, 2006b) and } \\
\text { radionuclides, or other contaminants, as } \\
\text { agreed upon by NNSA/NSO and NDEP }\end{array}$ & $\begin{array}{l}\text { No contaminants detected } \\
\text { above TCLP (CFR, 2006b) or } \\
\text { radionuclide action levels in } \\
\text { the soil beneath the waste zone }\end{array}$ & $\begin{array}{l}\text { Contaminants detected in soil sample above } \\
\text { TCLP (CFR, 2006b) or radionuclide action levels } \\
\text { (after background comparison) }\end{array}$ \\
\hline $\begin{array}{l}\text { Step 4: Deep Vadose } \\
\text { Zone Monitoring }\end{array}$ & $\begin{array}{l}\text { Install heat dissipation probes at } 10 \text {-meter } \\
\text { increments to } 100 \text { meters below ground } \\
\text { surface at one location outside the } 92-\text { Acre } \\
\text { Area to measure the water potential gradient }\end{array}$ & $\begin{array}{l}\text { No downward movement of } \\
\text { water in the deep vadose zone }\end{array}$ & $\begin{array}{l}\text { Trend of downward movement of water in the } \\
\text { deep vadose zone for } 2 \text { consecutive years }\end{array}$ \\
\hline $\begin{array}{l}\text { Step 5: Expanded } \\
\text { Groundwater Monitoring }\end{array}$ & $\begin{array}{l}\text { Install additional groundwater monitoring } \\
\text { well(s) at location(s) agreed upon by } \\
\text { NNSA/NSO and NDEP }\end{array}$ & $\begin{array}{l}\text { No contaminants or indicators } \\
\text { of contamination detected in } \\
\text { the groundwater }\end{array}$ & $\begin{array}{l}\text { Groundwater is the point of compliance. } \\
\text { Indicators of contamination that exceed the } \\
\text { limitations listed in Table } 4 \text { will be reported to } \\
\text { NDEP within } 14 \text { days of discovery. }\end{array}$ \\
\hline
\end{tabular}

*A volumetric moisture content of 30 percent is a conservative field capacity value for the soil in this area.

CFR: Code of Federal Regulations

NNSA/NSO: U.S. Department of Energy, National Nuclear Security Administration Nevada Site Office

NDEP: Nevada Division of Environmental Protection

RCRA: Resource Conservation and Recovery Act

TCLP: Toxicity Characterization Leaching Procedure

TDR: time-domain reflectometry 
Section: Conclusions and Recommendations

\subsection{RECOMMENDATIONS}

Because closure activities for the 92-Acre Area have been completed following Revision 1 of the CADD/CAP (NNSA/NSO, 2010) as documented in this CR, NNSA/NSO requests the following:

- A Notice of Completion from NDEP to NNSA/NSO for closure of CAU 111

- The transfer of CAU 111 from Appendix III to Appendix IV, Closed Corrective Action Units, of the FFACO

When the next request for modification of RCRA Permit NEV HW0101 is submitted to NDEP, the requirements for post-closure monitoring of the 92-Acre Area will be included. 
92-Acre Area and CAU 111

Closure Report

Section: Conclusions and Recommendations

Revision: 0

Date: February 2012

THIS PAGE INTENTIONALLY LEFT BLANK 


\subsection{REFERENCES}

CFR, see Code of Federal Regulations.

Code of Federal Regulations, 2006a. Title 40, Part 141, “National Primary Drinking Water Regulations.” Washington, D.C.

Code of Federal Regulations, 2006b. Title 40, Part 261, Subpart C, §261.24, “Toxicity Characteristic.” Washington, D.C.

CH2M HILL, 2010a. Design of Revisions to the Evapotranspiration Cover for the 92-Acre Area: Area 5 Waste Management Division Retired Mixed Waste Pits, Nevada National Security Site, Nevada. Sacramento, CA.

CH2M HILL, 2010b. Final Construction Quality Assurance Plan for 92-Acre Area Evapotranspiration Cover, Nevada National Security Site, Nevada. Document No. 10088-CQAP-01. Sacramento, CA.

Delphi Groupe, Inc., and J. A. Cesare and Associates, Inc., 2011. Evapotranspiration Cover for the 92-Acre Area Retired Mixed Waste Pits, Area 5 Waste Management Division, Nevada National Security Site, Interim CQA Report. DOE/NV/25946--1242. Las Vegas, NV.

Delphi Groupe, Inc., and J. A. Cesare and Associates, Inc., 2012. Evapotranspiration Cover for the 92-Acre Area Retired Mixed Waste Pits, Area 5 Waste Management Division, Nevada National Security Site, Final CQA Report. DOE/NV/25946--1428. Las Vegas, NV.

Federal Facility Agreement and Consent Order, 1996 (as amended March 2010). Agreed to by the State of Nevada; U.S. Department of Energy, Environmental Management; U.S. Department of Defense; and U.S. Department of Energy, Legacy Management.

Federal Facility Agreement and Consent Order, 2003. Use Restriction Posting Guidance.

FFACO, see Federal Facility Agreement and Consent Order.

NNSA/NSO, see U.S. Department of Energy, National Nuclear Security Administration Nevada Site Office.

U.S. Department of Energy, National Nuclear Security Administration Nevada Site Office, 2010. Corrective Action Decision Document/Corrective Action Plan for the 92-Acre Area and Corrective Action Unit 111: Area 5 WMD Retired Mixed Waste Pits, Nevada National Security Site, Nevada. DOE/NV--1326-REV.1. Las Vegas, NV. 
92-Acre Area and CAU 111

Closure Report

Section: References

Revision: 0

Date: February 2012

THIS PAGE INTENTIONALLY LEFT BLANK 
Section: Appendix A

Revision: 0

Date: February 2012

\section{APPENDIX A*}

\section{DATA QUALITY OBJECTIVES}

*As presented and published in the approved Corrective Action Decision Document/Corrective Action Plan for the 92-Acre Area and Corrective Action Unit 111: Area 5 WMD Retired Mixed Waste Pits, Nevada National Security Site, Nevada, 2010, DOE/NV--1326-REV.1. Las Vegas, NV. 
92-Acre Area and CAU 111

Closure Report

Section: Appendix A

Revision: 0

Date: February 2012

THIS PAGE INTENTIONALLY LEFT BLANK 


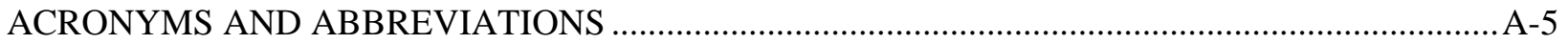

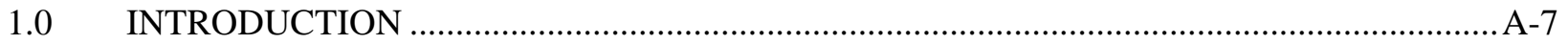

1.1 DOCUMENTS SUPPORTING SITE CHARACTERIZATION ................................................. A-8

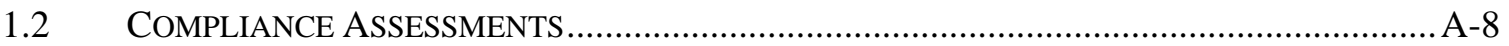

1.3 MANAGEMENT OF UNCERTAINTY AND WASTE INVENTORIES .................................... A-12

2.0 BACKGROUND INFORMATION .................................................................................

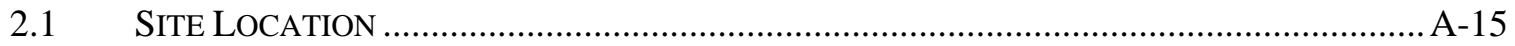

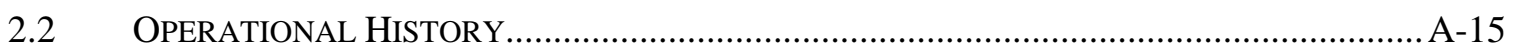

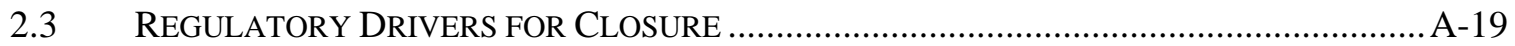

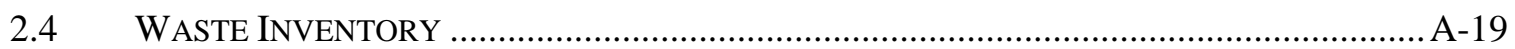

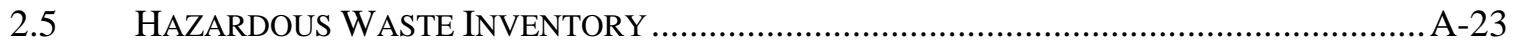

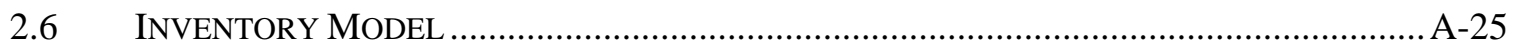

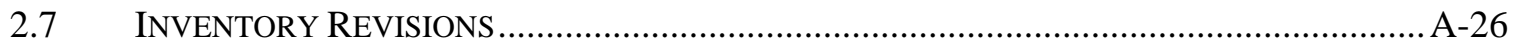

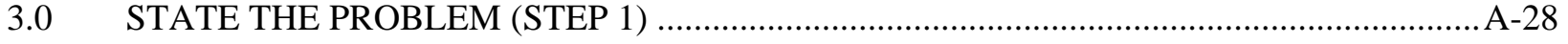

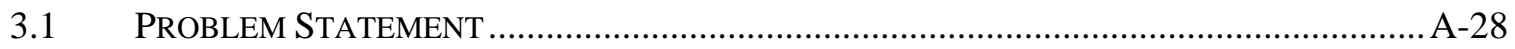

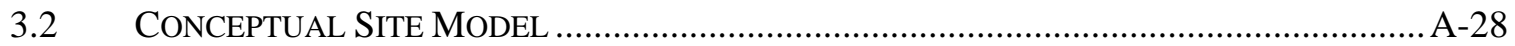

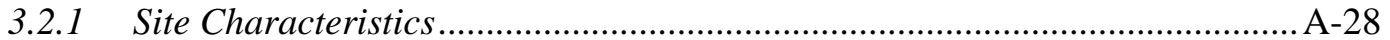

3.2.2 Facility Assessments Conceptual Model ......................................................33

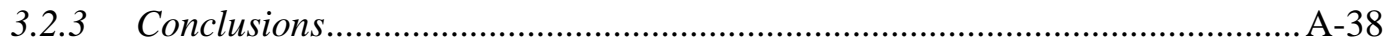

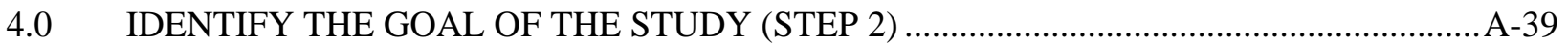

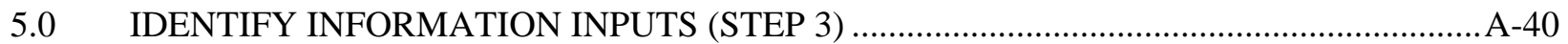

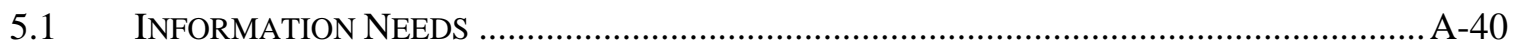

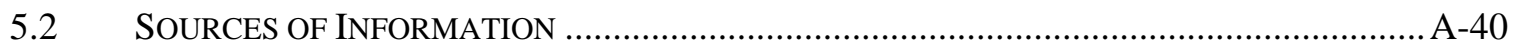

6.0 DEFINE THE BOUNDARIES OF THE STUDY (STEP 4) ..................................................42

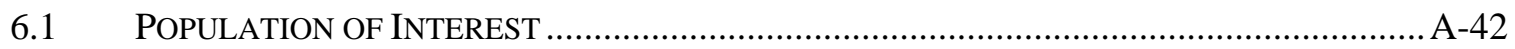

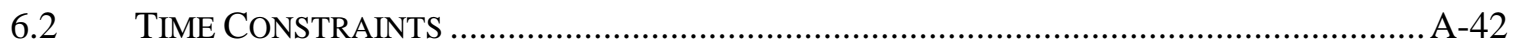

7.0 DEVELOP THE ANALYTIC APPROACH (STEP 5) .........................................................

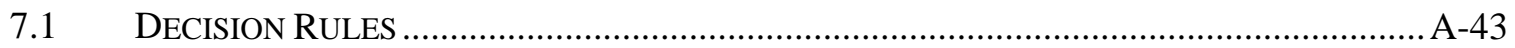

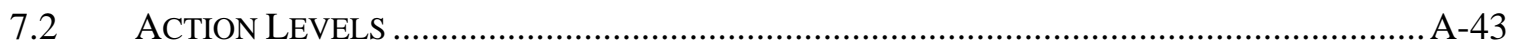

7.3 MEASUREMENT AND ANALYSIS SENSITIVITY …....................................................... A-43

8.0 SPECIFY PERFORMANCE OR ACCEPTANCE CRITERIA (STEP 6) .................................44

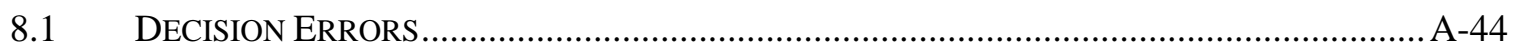

9.0 DEVELOP THE PLAN FOR OBTAINING DATA (STEP 7) ……........................................45

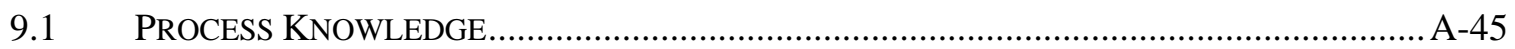

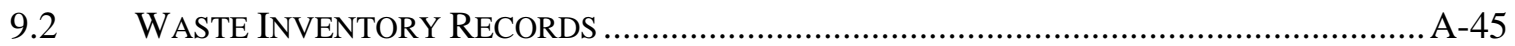

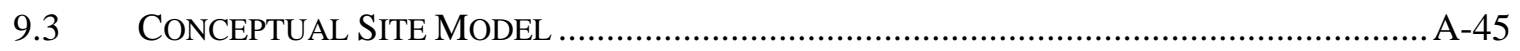

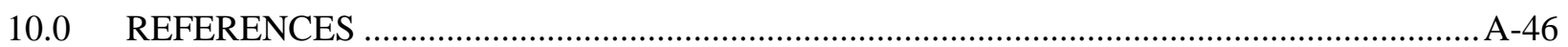




\section{FIGURES}

Figure A-1. Steel Drums Over-Packed into Larger Steel Containers at the Area 5

RADIOACTIVE WASTE MANAGEMENT SitE A-14

Figure A-2. Area 5 Radioactive Waste Management Site Location Map. A-16

Figure A-3. 92-ACRE AREA Disposal UNiTS A-17

Figure A-4. PA Model of Unsaturated Flow in the Vadose Zone A-34

\section{TABLES}

TABle A-1. Summary of PA Results And Compliance EVAlUATION.............................. A-10

TABle A-2. Summary of CA Results AND Compliance Evaluation.............................. A-10

TABlE A-3. SUMMARY OF PA RESUltS AND COMPLIANCE EVALUATION UNDER THE 1985 VERSION OF 40 CFR 191 FOR THE TRU WASTE IN THE GCD BOREHOLES .... A-11

TABLE A-4. SUMMARY OF SA RESULTS AND COMPARISON WITH THE STANDARDS CONTAINED IN THE 1997 VERSION OF 40 CFR 191 FOR THE TRU WASTE IN TRENCH T04A.

Table A-5. Sensitivity of the Transient Visitor Air Pathway TEDE at 1,000 YEARS A-13

Table A-6. Sensitivity of the Resident Farmer All Pathways TEDE at 1,000 YEARS. A-13

TABle A-7. Sensitivity of THE RAdON-222 Flux Density at 1,000 YeARS. A-14

TABle A-8. 92-ACRE AREA WASte Unit STATUS A-20

TABle A-9. CAU 111 Cell Designations A-24

TABLE A-10. CAU 111 Hazardous WAste Constituents A-25 


\section{ACRONYMS AND ABBREVIATIONS}

ALARA

ANSI

$\mathrm{BN}$

$\mathrm{Bq} \mathrm{L}^{-1}$

$\mathrm{Bq} \mathrm{m}{ }^{-2} \mathrm{~s}^{-1}$

CA

CADD/CAP

CAU

CFR

CR

CSM

DAS

DASH

DCG

DOE

DQO

EPA

FEHM

FFACO

$\mathrm{ft}$

$\mathrm{ft}^{3}$

FY

GCD

GCDT

ICMP

in.

IPR

LLW

LWIS

$\mathrm{M}$

MFP

mi

$\mathrm{mm} / \mathrm{yr}$ as low as reasonably achievable

American National Standards Institute

Bechtel Nevada

Becquerel(s) per liter

Becquerel(s) per square meter per second

composite analysis

Corrective Action Decision Document/Corrective Action Plan

Corrective Action Unit

Code of Federal Regulations

containment requirement

conceptual site model

Disposal Authorization Statement

Deep Arid System Hydrodynamic

Derived Concentration Guide

U.S. Department of Energy

data quality objective

U.S. Environmental Protection Agency

finite element heat and mass transfer

Federal Facility Agreement and Consent Order

foot (feet)

cubic foot (feet)

fiscal year

Greater Confinement Disposal

Greater Confinement Disposal Test

integrated closure and monitoring plan

inch(es)

individual protection requirement

low-level waste

Low-Level Waste Information System

Manual

mixed fission product

mile(s)

millimeter(s) per year 


$\begin{array}{ll}\text { MOP } & \text { member of the public } \\ \text { mph } & \text { mile(s) per hour } \\ \text { mR/day } & \text { milliroentgen(s) per day } \\ \text { mrem/yr } & \text { millirem(s) per year } \\ \text { mSv/yr } & \text { milliSievert(s) per year } \\ \text { MTRU } & \text { mixed transuranic } \\ \text { MW } & \text { mixed waste } \\ \text { MWDU } & \text { Mixed Waste Disposal Unit } \\ \text { NAC } & \text { Nevada Administrative Code } \\ \text { NDEP } & \text { Nevada Division of Environmental Protection } \\ \text { NCRP } & \text { National Council on Radiation Protection and Measurements } \\ \text { NFB } & \text { no-flux boundary } \\ \text { NNSA/NSO } & \text { U.S. Department of Energy, National Nuclear Security Administration } \\ \text { NTS } & \text { Nevada Site Office } \\ \text { NWAR } & \text { Nevada Test Site } \\ \text { O } & \text { nuclear weapons accident residue } \\ \text { PA } & \text { Order } \\ \text { PET } & \text { performance assessment } \\ \text { pdf } & \text { potential evapotranspiration } \\ \text { QA/QC } & \text { probability density function } \\ \text { RCRA } & \text { quality assurance/quality control } \\ \text { REECo } & \text { Resource Conservation and Recovery Act } \\ \text { RWM } & \text { Reynolds Electrical and Engineering Company, Inc. } \\ \text { RWMS } & \text { Radioactive Waste Management } \\ \text { SA } & \text { Radioactive Waste Management Site } \\ \text { SLB } & \text { special analysis } \\ \text { TDR } & \text { Shallow Land Burial } \\ \text { TEDE } & \text { time-domain reflectometry } \\ \text { TRU } & \text { total effective dose equivalent } \\ \text { WMD } & \text { transuranic } \\ & \text { Waste Management Division } \\ & \end{array}$




\subsection{INTRODUCTION}

The data quality objective (DQO) process is a seven-step systematic planning method based on the scientific method. The information presented in this document is based on characterization and monitoring data, historical documentation and records, modeling studies, evaluations, and process knowledge for the southeast quadrant of the Area 5 Radioactive Waste Management Site (RWMS), which is referred to as the "92-Acre Area." The DQOs were developed according to the U.S. Environmental Protection Agency (EPA) Guidance on Systematic Planning Using the Data Quality Objectives Process (EPA, 2006). The steps systematically build on the data acquired during preliminary assessment work and background research.

The Area 5 RWMS uses engineered shallow-land burial cells to dispose of packaged waste. The cells in the 92-Acre Area include 13 boreholes, 16 narrow trenches, and 9 broader pits. The waste disposal units have been established over a 45-year operation period. Three disposal units within the 92-Acre Area are currently active. All other pits and trenches have been operationally closed with temporary earthen covers of at least 8 feet (ft) of native fill.

The 92-Acre Area includes Federal Facility Agreement and Consent Order (FFACO) Corrective Action Unit (CAU) 111, Area 5 WMD Retired Mixed Waste Pits, which consists of 11 trenches and pits that may have received both low-level waste (LLW) and mixed waste (MW) prior to the promulgation of the Resource Conservation and Recovery Act (RCRA). The 92-Acre Area also contains an active MW pit, two units which received asbestiform LLW, and six disposal units that are known or suspected to have received some transuranic (TRU) waste. The 92-Acre Area has been divided into six units based on physical location, waste types, and regulatory requirements:

- $\quad$ Pit 3 Mixed Waste Disposal Unit (MWDU)

- CAU 111, Area 5 WMD Retired Mixed Waste Pits

- CAU 207, Archived - Area 5 WMD Greater Confinement Disposal (GCD) Boreholes

- LLW disposal units

- Asbestiform LLW disposal units

- $\quad$ One TRU waste trench

Sufficient information is available about the physical, chemical, hydrological, plant, animal, and climate characteristics, as well as facility design, operation, and source materials to provide the input data necessary to evaluate closure options without the collection of additional data. Site characterization activities at the Area 5 RWMS began in the early 1990s. These activities have provided the necessary data to develop a conceptual site model (CSM) for the fate and transport of the waste inventory. The CSM, inventory, and release and transport parameters are presented in this document along with a discussion of their uncertainty. References that provide detailed information regarding characterization and modeling studies are provided. 


\subsection{Documents Supporting Site Characterization}

Documents related to characterization and site performance are listed below:

- Area 5 Site Characterization Project Report FY 1994 (Albright et al., 1994)

- Characterization Report: Operational Soil Covers for the Area 5 Radioactive Waste Management Sites at the Nevada Test Site (Bechtel Nevada [BN], 2005a)

- Hydrogeologic Characterization Data from the Area 5 Shallow Soil Trenches, Nevada Test Site, Nye County, Nevada (BN, 2005b)

- Site Characterization and Monitoring Data for the Area 5 Pilot Wells, Nevada Test Site, Nye County, Nevada (BN, 2005c)

- Addendum 2 to the Performance Assessment of the Area 5 RWMS at the NTS, Nye County, Nevada Update of the Performance Assessment Methods and Results (BN, 2006)

- Site Characterization Data from the Area 5 Science Boreholes, Nevada Test Site, Nye County, Nevada (Blout et al., 1995)

- Use of Long-Term Lysimeter Data in Support of Shallow Land Waste Disposal Cover Design (Desotell et al., 2006)

- Hydrogeologic Data for Existing Excavations at the Area 5 Radioactive Waste Management Site, Nevada Test Site, Nye County, Nevada (Reynolds Electrical and Engineering Company, Inc. [REECo], 1993a)

- Hydrogeologic Data for Science Trench Boreholes at the Area 5 Radioactive Waste Management Site, Nevada Test Site, Nye County, Nevada (REECo, 1993b)

- Flood Assessment at the Area 5 Radioactive Waste Management Site and the Proposed Hazardous Waste Storage Unit, Nevada Test Site, Nye County, Nevada (Schmeltzer et al., 1993)

- Performance Assessment of the Area 5 Radioactive Waste Management Site at the Nevada Test Site, Nye County, Nevada, Revision 2.1 (Shott et al., 1998)

- Soil-Water Flux in the Southern Great Basin, United States: Temporal and Spatial Variations over the Last 120,000 Years (Tyler et al., 1996)

- Vadose-zone Fluid and Solute Flux: Advection and Diffusion at the Area 5 Radioactive Waste Management Site (Wolfsberg and Stauffer, 2003)

\subsection{Compliance Assessments}

Four major assessments have been completed that demonstrate waste disposal operations at the Area 5 RWMS are in compliance with the U.S. Department of Energy (DOE) regulations and provide assurance that members of the public (MOPs) and the environment will be protected for 1,000 years after closure. These assessments include (1) the LLW performance assessment (PA), (2) the composite analysis (CA), (3) the PA for the TRU waste in the GCD boreholes, and (4) the special analysis (SA) for the TRU waste in trench T04A.

The PA, the CA, and the integrated closure and monitoring plan (ICMP) are the basis for the Disposal Authorization Statement (DAS) for the Area 5 RWMS. DOE issued the DAS for the operation of the Area 5 disposal facility in December 2000. 


\subsubsection{Performance Assessment for the Area 5 RWMS}

The Area 5 PA evaluates radiological impacts of LLW regulated by DOE Order (O) 435.1, "Radioactive Waste Management” (DOE, 1999a). Regulated LLW is limited to waste disposed from September 26, 1988, to the assumed closure date of September 30, 2028. Radiological hazards are assessed for a period of 1,000 years after site closure. The purpose of the PA is to determine if there is a reasonable expectation of compliance with the performance objectives in the DOE Radioactive Waste Management Manual, Chapter IV, Section P(1) (DOE, 1999a):

1) The dose to representative MOPs shall not exceed 0.25 milliSieverts per year (mSv/yr) total effective dose equivalent (TEDE) from all exposure pathways, excluding the dose from radon and its progeny in air.

2) The dose to representative MOPs via the air pathway shall not exceed $0.10 \mathrm{mSv} / \mathrm{yr} \mathrm{TEDE}$, excluding the dose from radon and its progeny.

3) The release of radon shall be less than an average flux of 0.74 Becquerel per square meter per second $\left(\mathrm{Bq} \mathrm{m} \mathrm{m}^{-2} \mathrm{~s}^{-1}\right)$ at the surface of the disposal facility. Alternatively, a limit of 0.0185 Becquerel per liter $\left(\mathrm{Bq} \mathrm{L}^{-1}\right)$ of air may be applied at the boundary of the facility.

Representative MOPs are interpreted to be members of the critical group engaged in typical activities expected for the region. The critical group includes those MOPs exposed to the highest radionuclide releases from the site. The MOP is assumed to be located 100 meters from the boundary of the total area of the disposal units. The average radon flux is interpreted to be the spatially averaged flux density calculated as the total site radon flux from the ground surface to the atmosphere, divided by the total area of the disposal units. In addition to providing a reasonable expectation that the performance objectives are not exceeded, the PA must also demonstrate that radionuclide releases are as low as reasonably achievable (ALARA).

Under DOE Manual (M) 435.1-1, "Radioactive Waste Management Manual” (DOE, 1999b), a PA must include an assessment of (1) impacts to groundwater and (2) impacts to a hypothetical person assumed to inadvertently intrude for a temporary period into the disposal facility. The results are used to set limits for radionuclides disposed in the near-surface. Groundwater impacts are assessed against the standards in the National Primary Drinking Water Regulations (Title 40 Code of Federal Regulations [CFR] Part 141). Intruder impacts are limited to ensure that the TEDE received by a chronically exposed intruder is less than $1.0 \mathrm{mSv}$. In the case of the Area 5 RWMS, the groundwater protection criteria are not used to set limits for radionuclides disposed in the near-surface. Site characterization data support a conclusion that a groundwater pathway is extremely unlikely (Shott et al., 1998). Table A-1 summarizes the PA results.

The PA was approved after a peer review with conditions by DOE in August 1996 (Shott et al., 1998). The DAS conditions were removed in May 2002 with acceptance of an addendum to the PA (BN, 2001a). Under the PA maintenance program, disposal site operations, waste inventories, research and development, and environmental monitoring results are reviewed annually, and the adequacy of the PA is evaluated. The 2004 annual review concluded that significant changes have occurred since preparation of the PA, and consequently, a second addendum was prepared and accepted without conditions in 2006 (BN, 2006). 
TAble A-1. Summary of PA Results ANd Compliance Evaluation

\begin{tabular}{|c|c|c|c|c|c|}
\hline \multirow[b]{2}{*}{$\begin{array}{l}\text { PERFORMANCE } \\
\text { OBJECTIVE }\end{array}$} & \multirow[b]{2}{*}{ LIMIT } & \multicolumn{3}{|c|}{ LIMITING RESULT } & \multirow[b]{2}{*}{ CONCLUSION } \\
\hline & & SCENARIO & MEAN & $\begin{array}{c}95^{\mathrm{TH}} \\
\text { PerCENTILE }\end{array}$ & \\
\hline Air Pathway & $0.1 \mathrm{mSv} / \mathrm{yr}$ & $\begin{array}{l}\text { Transient } \\
\text { Occupancy }\end{array}$ & 4.1E-5 mSv/yr & 4.7E-4 mSv/yr & Complies \\
\hline All Pathways & $0.25 \mathrm{mSv} / \mathrm{yr}$ & Resident Farmer & $4.4 \mathrm{E}-2 \mathrm{mSv} / \mathrm{yr}$ & $3.9 \mathrm{E}-2 \mathrm{mSv} / \mathrm{yr}$ & Complies \\
\hline $\begin{array}{l}\text { Intruder Protection } \\
\text { (Acute Exposure) }\end{array}$ & $5 \mathrm{mSv}$ & \multicolumn{3}{|c|}{ Bounded by chronic exposure scenarios } & Complies \\
\hline $\begin{array}{l}\text { Intruder Protection } \\
\text { (Chronic Exposure) }\end{array}$ & $1 \mathrm{mSv}$ & $\begin{array}{l}\text { SLB Intruder } \\
\text { Agriculture }\end{array}$ & $0.12 \mathrm{mSv}^{*}$ & $0.43 \mathrm{mSv}^{*}$ & Complies \\
\hline Radon Flux Density & $0.74 \mathrm{~Bq} \mathrm{~m}^{-2} \mathrm{~s}^{-1}$ & $\begin{array}{l}\text { All Disposal } \\
\text { Units }\end{array}$ & $0.044 \mathrm{~Bq} \mathrm{~m}^{-2} \mathrm{~s}^{-1}$ & $0.096 \mathrm{~Bq} \mathrm{~m}^{-2} \mathrm{~s}^{-1}$ & Complies \\
\hline $\begin{array}{l}\text { Groundwater } \\
\text { Protection }\end{array}$ & 40 CFR 141 & \multicolumn{3}{|c|}{ No groundwater pathway in 1,000 years } & Complies \\
\hline Releases ALARA & No Limit & \multicolumn{3}{|c|}{ Optimum cover thickness less than 13 feet } & ALARA \\
\hline $\begin{array}{l}\text { ALARA: as low as } \\
\text { Bq } \mathrm{m}^{-2} \mathrm{~s}^{-1}: \text { Becquere } \\
\text { CFR: Code of Feder }\end{array}$ & $\begin{array}{l}\text { per square m } \\
\text { Regulations }\end{array}$ & $\begin{array}{l}\mathrm{mSv} / \mathrm{y} \\
\text { SLB: } \\
\text { *Weig }\end{array}$ & $\begin{array}{l}\text { iilliSievert(s) per year } \\
\text { llow Land Burial } \\
\text { I with probability of in }\end{array}$ & & \\
\hline
\end{tabular}

\subsubsection{Composite Analysis for the Area 5 RWMS}

The purpose of the CA is to determine if the continuing operation of the Area 5 RWMS poses an acceptable risk to the public considering the total waste inventory, regardless of disposal date, and all other interacting sources of radioactive material in the vicinity. Continuing operation of the facility is acceptable if the TEDE is less than 100 millirems per year (mrem/yr). If the TEDE exceeds $30 \mathrm{mrem} / \mathrm{yr}$, a cost-benefit options analysis must be performed to determine if cost-effective management options exist to reduce the dose further. If the TEDE is found to be less than $30 \mathrm{mrem} / \mathrm{yr}$, an analysis may be performed to determine if doses are ALARA.

The maximum CA dose to a MOP for the 1,000-year compliance period is $1 \mathrm{mrem} / \mathrm{yr}$ $(0.01 \mathrm{mSv} / \mathrm{yr})$ at 1,000 years after closure. The Area 5 CA was accepted by DOE with conditions in 2001 (BN, 2001b), and an addendum was issued in 2001 (BN, 2001c). The CA evaluated the dose to a future MOP from all sources of radionuclides in the ground in Frenchman Flat and the releases from the facility, including all pre-1988 waste in the disposal cells. Table A-2 summarizes the CA results for the Area 5 RWMS.

TABle A-2. Summary of CA Results ANd Compliance Evaluation

\begin{tabular}{|c|c|c|c|c|c||}
\hline \multirow{2}{*}{$\begin{array}{c}\text { PERFORMANCE } \\
\text { ObJeCTIVE }\end{array}$} & \multirow{2}{*}{ LIMIT } & \multicolumn{3}{|c|}{ LIMITING RESULT } & \multirow{2}{*}{ CONCLUSION } \\
\cline { 4 - 5 } & & SCENARIO & MEAN & $\begin{array}{c}\text { 95 }^{\mathrm{TH}} \\
\text { PERCENTILE }^{*}\end{array}$ \\
\hline \hline All Pathways/All Sources & $0.3 \mathrm{mSv}$ & Resident & $0.01 \mathrm{mSv}$ & $0.04 \mathrm{mSv}$ & Complies \\
\hline
\end{tabular}

mSv: milliSievert(s) 


\subsubsection{Performance Analysis for the TRU Waste in the GCD Boreholes}

The TRU waste in GCD boreholes 1 through 4 was evaluated to demonstrate compliance with the requirements of 40 CFR 191, "Environmental Radiation Protection Standards for Management and Disposal of Spent Nuclear Fuel, High-Level, and Transuranic Radioactive Wastes.” Relevant standards for TRU waste disposal are found in 40 CFR 191 Subpart B, "Environmental Standards for Disposal," and Subpart C, "Environmental Standards for Groundwater Protection.” Subpart B standards include containment requirements (CRs), assurance requirements, and individual protection requirements (IPRs). The CRs are probabilistic limits for the normalized cumulative radionuclide release to the accessible environment for 10,000 years. The cumulative release is normalized to release limits scaled to the total TRU inventory disposed. The CRs limit the probability of exceeding the release limit to 1 chance in 10, and the probability of exceeding 10 times the release limit to 1 chance in 1,000. The assurance requirements specify institutional controls and disposal system features to increase confidence in the long-term compliance with the CRs. The required controls and features are active and passive institutional controls, monitoring, natural and engineered barriers, lack of attractive natural resources, and ability to retrieve wastes for a reasonable time period. The IPRs limit the committed effective dose to a MOP through all pathways for 10,000 years to $0.15 \mathrm{mSv} / \mathrm{yr}$. Subpart C requires that sources of underground drinking water in the accessible environment comply with the limits in 40 CFR 141 for a period of 10,000 years.

Sandia National Laboratories prepared a PA for the TRU GCD boreholes in 2001 (Cochran et al., 2001). In 2002, DOE determined that the PA met all requirements with the exception of the 40 CFR 191.14 assurance requirements for institutional controls; a monitoring program; markers, records, and other passive institutional controls; an engineered barrier system; information to support the claim that there are no economically useful minerals in the area; and removal of waste. The U.S. Department of Energy, National Nuclear Security Administration Nevada Site Office (NNSA/NSO) committed to resolve these issues during the closure planning process for the Area 5 RWMS (Colarusso et al., 2003). The TRU Federal Review Group would review closure and post-closure documents to determine compliance with the 1993 version of 40 CFR 191 (Fiore and Berube, 2002). A new assurance requirements document is being prepared. Table A-3 summarizes the PA results for the TRU waste in the GCD boreholes.

\section{TABle A-3. Summary of PA Results ANd Compliance Evaluation under the 1985 VERSION OF 40 CFR 191 FOR THE TRU WASTE IN THE GCD BOREHOLES}

\begin{tabular}{|c|c|c|c|c|c|}
\hline \multirow{2}{*}{$\begin{array}{l}\text { PERFORMANCE } \\
\text { OBJECTIVE }\end{array}$} & \multirow{2}{*}{ LIMIT } & \multicolumn{3}{|c|}{ LIMITING RESULT } & \multirow{2}{*}{ CONCLUSION } \\
\hline & & SCENARIO & MEAN & MAXIMUM & \\
\hline Containment Requirements & $\mathrm{P}(\mathrm{R}>1)<0.1$ & \multicolumn{3}{|c|}{$\mathrm{P}(\mathrm{R}>1)<0.0002$} & Complies \\
\hline Containment Requirements & $\mathrm{P}(\mathrm{R}>10)<0.001$ & \multicolumn{3}{|c|}{$\mathrm{P}(\mathrm{R}>10)<0.0002$} & Complies \\
\hline $\begin{array}{c}\text { Individual Protection } \\
\text { Requirements } \\
\end{array}$ & $\begin{array}{c}0.25 \mathrm{mSv} \\
\text { Whole Body }\end{array}$ & $\begin{array}{l}\text { Resident } \\
\text { Farmer }\end{array}$ & 4.7E-5 mSv & $1.6 \mathrm{E}-3 \mathrm{mSv}$ & Complies \\
\hline $\begin{array}{c}\text { Individual Protection } \\
\text { Requirements } \\
\end{array}$ & $\begin{array}{l}0.75 \mathrm{mSv} \\
\text { Any Organ }\end{array}$ & $\begin{array}{l}\text { Resident } \\
\text { Farmer }\end{array}$ & $\begin{array}{c}1.2 \mathrm{E}-3 \mathrm{mSv} \\
\text { Bone }\end{array}$ & $\begin{array}{c}\text { 4.5E-2 mSv } \\
\text { Bone }\end{array}$ & Complies \\
\hline $\begin{array}{c}\text { Groundwater Protection } \\
\text { Standard }\end{array}$ & 40 CFR 141 & \multicolumn{3}{|c|}{$\begin{array}{l}\text { Not applicable under } 1985 \text { version of } \\
\text { 40 CFR } 191\end{array}$} & Complies \\
\hline
\end{tabular}

$\mathrm{P}(\cdot)$ : Probability of an event

R: Normalized cumulative release as defined in 40 CFR 191.27 mSv: milliSievert(s) 


\subsubsection{Special Analysis for the TRU Waste in Trench T04A}

In 1986, 102 55-gallon drums of TRU waste from Rocky Flats were inadvertently buried in T04A. The T04A TRU inventory was included in the $2001 \mathrm{CA}$; however, in order to provide further assurance that this small quantity of TRU in T04A will not pose a risk to future members of public, a 40 CFR 191 evaluation is considered relevant.

The SA was performed in 2007 to determine the likelihood that T04A meets the requirements of 40 CFR 191 (Shott et al., 2008). The SA concludes that there is a reasonable expectation that all 40 CFR 191 disposal requirements for a period of 10,000 years under climate change are met. Table A-4 summarizes the SA results for the TRU waste T04A.

\section{TABLE A-4. SUMMARY OF SA RESUlTS AND COMPARISON WITH THE STANDARDS CONTAINED IN THE 1997 VERSION OF 40 CFR 191 FOR THE TRU WASTE IN TRENCH T04A}

\begin{tabular}{|c|c|c|c|c|c|}
\hline \multirow[b]{2}{*}{ PERFORMANCE OBJECTIVE } & \multirow[b]{2}{*}{ LIMIT } & \multicolumn{3}{|c|}{ LIMITING RESULT } & \multirow[b]{2}{*}{ CONCLUSION } \\
\hline & & SCENARIO & MEAN & $\begin{array}{c}95^{\mathrm{TH}} \\
\text { PERCENTILE } \\
\end{array}$ & \\
\hline "Containment Requirements & $\mathrm{P}(\mathrm{R}>1)<0.1$ & \multicolumn{3}{|c|}{$\mathrm{P}(\mathrm{R}>1)=0.009$} & Meets Standard \\
\hline Containment Requirements & $\mathrm{P}(\mathrm{R}>10)<0.001$ & \multicolumn{3}{|c|}{$\mathrm{P}(\mathrm{R}>10)<0.0001$} & Meets Standard \\
\hline $\begin{array}{l}\text { Individual Protection } \\
\text { Requirements }\end{array}$ & $0.15 \mathrm{mSv}$ & Resident & $0.055 \mathrm{mSv}$ & $0.15 \mathrm{mSv}$ & Meets Standard \\
\hline $\begin{array}{c}\text { Groundwater Protection } \\
\text { Standard }\end{array}$ & 40 CFR 141 & \multicolumn{3}{|c|}{ No groundwater pathway in 10,000 years } & Meets Standard \\
\hline
\end{tabular}

$\mathrm{P}(\cdot)$ : Probability of an event

R: Normalized cumulative release as defined in 40 CFR 191.27 mSv: milliSievert(s)

\subsection{MANAGEMENT OF UNCERTAINTY AND WASTE INVENTORIES}

Performance assessment is an iterative process. The process begins with conservative deterministic screening models. The goal of each iteration is to reduce uncertainty in system performance. As the understanding of system performance improves and additional site characterization and monitoring results become available, conservative models can be replaced with increasingly realistic probabilistic models, parameterized with probability density functions (pdfs) that represent expected values and their uncertainty.

The current PA model in GoldSim ${ }^{\circledR}$ is probabilistic with all input parameters represented by probability distributions, thus accounting for the uncertainty in the parameter values. The parameter distributions have been developed with additional field work since 2000. The Maintenance Plan for the Area 5 PA and CA calls for additional field investigations for those parameters that are shown to be sensitive and uncertain. If a parameter is found to be highly sensitive, further investigation is justified. However, for those parameters that are uncertain but insensitive, no further data collection and reduction in uncertainty is warranted.

Comprehensive sensitivity analyses were performed for the PA model using local and global methods to explore sensitivity in model response over the entire parameter value ranges (BN, 2006). The sensitive parameters are related to plant uptake and animal burrowing. Individual radionuclide inventories were found to be insensitive; therefore, additional inventory characterization is not warranted. The relative insensitivity of the inventory highlights the robust nature of the disposal system to contain waste and protect public health and safety. 
The Area 5 RWMS PA/CA model has undergone several iterations. The probabilistic model's parameter distributions are selected to represent expected values and their uncertainty. The following conservative assumptions reflect areas with persistent parameter or model uncertainty:

- The critical group is assumed to be a resident farmer 100 meters from the site. The Area 5 RWMS is extremely remote and arid with marginal agricultural soils. The lack of attractive resources, including surface water or shallow groundwater, makes this an unlikely site for future residential development. The lack of water and suitable soils makes agriculture at the site extremely unlikely. The presence of nuclear subsidence craters in the area is also likely to remind residents far in the future of the potential presence of radioactive contamination. In addition to natural conditions, land use plans are to restrict public access in perpetuity.

- All radionuclides are assumed to be immediately available for release and transport. However, containers and waste forms are likely to delay the release of radionuclides to the near field for decades if not hundreds of years.

- The critical group, 100 meters from the site boundary, is assumed to be exposed to onsite surface soil radionuclide concentrations. Actual soil concentrations, 100 meters from the site boundary, are expected to be orders of magnitude less than onsite concentrations.

- The radon-222 emanation coefficient, a sensitive model parameter, is assumed to be uniformly distributed from 0.02 to 0.8 . This distribution reflects a maximum state of uncertainty, and the limits are the physically reasonable limits for this parameter in a solid sample. A more conservative distribution is a physical impossibility.

- The technetium plant-soil concentration ratio, a sensitive model parameter, is assumed to be lognormally distributed with a geometric standard deviation of 5.70. This implies that 95 percent of sampled values will fall within a broad 1,300-fold range. This range represents a maximum state of uncertainty reflecting spatial and temporal variation, and variability among species, climates, and soil types.

Tables A-5 and A-6 summarize the relative influence of parameters for the air pathway and all pathways. The relative influence measures the percent of the regression model variance that is explained by the parameter. The sensitivity analysis indicates that the Area 5 RWMS PA model is insensitive to waste inventory for the air pathway and all pathways TEDE for the scenarios with the highest dose.

\section{TABLE A-5. Sensitivity OF THE TRANSIENT VisitoR Air Pathway TEDE at 1,000 Years}

\begin{tabular}{|l|c|}
\hline \multicolumn{1}{|c|}{ PARAMETER } & RELATIVE INFLUENCE \\
\hline \hline Messor pergandei burrow volume depth distribution (b parameter) & 37.1 \\
\hline Shallow land burial radon-222 emanation coefficient & 8.73 \\
\hline
\end{tabular}

TABLE A-6. SENSITIVITY OF THE RESIDENT FARMER All Pathways TEDE at 1,000 Years

\begin{tabular}{|l|c|}
\hline \multicolumn{1}{|c|}{ PARAMETER } & RELATIVE INFLUENCE \\
\hline \hline Technetium plant-soil concentration ratio for crops & 23.9 \\
\hline Depth of the no liquid flux boundary & 5.95 \\
\hline
\end{tabular}


Table A-7 illustrates that the radon-222 flux density is moderately sensitive to the Pit 13 thorium-230 inventory and the future thorium-230 inventory.

TABle A-7. Sensitivity Of THE RAdON-222 FluX Density at 1,000 Years

\begin{tabular}{|l|c|}
\hline \multicolumn{1}{|c|}{ PARAMETER } & RELATIVE INFLUENCE \\
\hline \hline Shallow land burial radon-222 emanation coefficient & 40.0 \\
\hline Pit 13 thorium-230 inventory & 26.1 \\
\hline Future shallow land burial thorium-230 inventory & 14.8 \\
\hline Pit 13 radon-222 emanation coefficient & 11.2 \\
\hline \hline
\end{tabular}

The parameter sensitivity of the CA was assessed using the rank correlation coefficient. The CA TEDE at 1,000 years was moderately sensitive to the closure cover thickness, the maximum depth of biological activity, the technetium plant-soil concentration ratio, the chlorine plant-soil concentration ratio, the technetium-99 inventory, and the chlorine-36 inventory.

Due to the difficulty of modeling the releases from the waste containers and waste forms (e.g., corrosion rates, and dissolution and diffusive properties of the various waste forms) with any certainty, the PAs make the bounding assumption that all waste is released into the backfill soil at closure. Although not quantified, it is reasonable to assume that the integrity of some containers would significantly reduce release of waste, at least in the near term. For example, Figure A-1 shows how steel drums have been over-packed into larger steel containers.

Since no credit is taken for waste containers and waste forms, the PA results are conservative. Moreover, the results, with conservative assumptions, are far below the performance objectives, indicating further reduction of uncertainty of source material is not warranted. In summary, further data collection is not necessary to evaluate closure options for these disposal units.

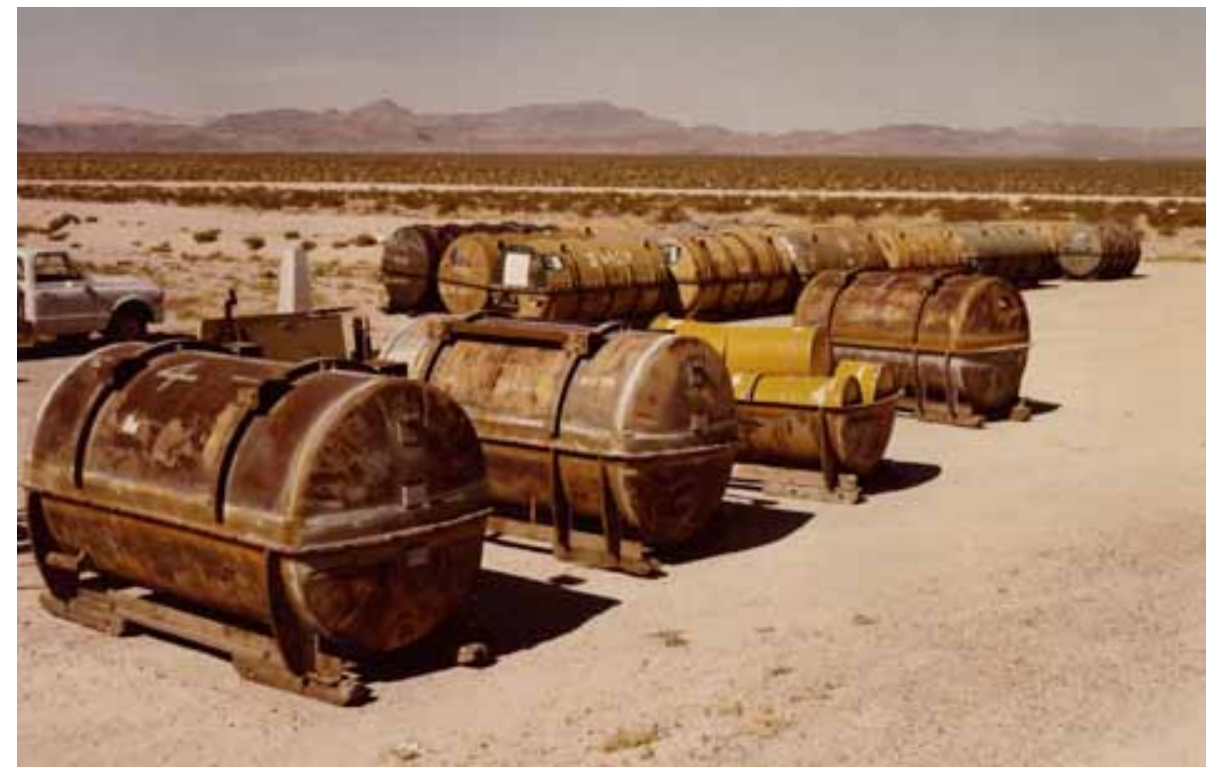

Figure A-1. Steel Drums OVer-Packed into LARger Steel Containers at the Area 5 Radioactive Waste Management Site 


\subsection{BACKGROUND INFORMATION}

This section summarizes the waste disposal operations at the Area 5 RWMS. The site location, operational history, and waste inventory are discussed briefly. More detail can be found in the Integrated Closure and Monitoring Plan for the Area 3 and Area 5 Radioactive Waste Management Sites at the Nevada Test Site (BN, 2005d) and the Area 5 RWMS PA (Shott et al., 1998).

\subsection{SiTE LOCATION}

The 92-Acre Area is located in Area 5 of the Nevada Test Site (NTS), which is approximately 65 miles (mi) northwest of Las Vegas, Nevada. The 92-Acre Area constitutes the southeast quadrant of the Area 5 RWMS (Figure A-2).

The Area 5 RWMS is located in a topographically closed basin approximately 14 mi north of Mercury, Nevada, in the north-central part of Frenchman Flat, and approximately 15 mi south of the Area 3 RWMS, which is in south-central Yucca Flat.

Figure A-3 shows the disposal units of the 92-Acre Area. The disposal unit names are coded. Each shallow excavation is categorized as either a "trench" (designated with the prefix " $\mathrm{T}$ ”) or a "pit” (designated with the prefix "P”), based on width. Generally pits are greater than $100 \mathrm{ft}$ wide and are large enough for a truck to turn around. The borehole designations have the prefix "GCD."

\subsection{OPERATIONAL HistORY}

Both classified and unclassified materials have been managed at the Area 5 RWMS. Disposal records and historic records for the 92-Acre Area include the following waste types: LLW, MW, asbestiform waste, TRU waste, and mixed transuranic (MTRU) waste. The majority of the inventory is LLW. Most of the TRU and MTRU waste was placed in boreholes more than $70 \mathrm{ft}$ below ground surface. Two disposal units have been designated for asbestos waste. Much of the MW was deposited in the oldest disposal units prior to the promulgation of RCRA.

The precursor to the Area 5 RWMS, the Sugar Bunker Dump, began receiving waste by 1960 and began burying waste in January 1961, prior to the origination of federal radioactive waste management regulations and RCRA. Information on the earliest inventory and disposal practices is more general and less complete than in later years. Disposal records for some trenches are limited. Analytical profiling initially focused on radioactivity, but from process knowledge and general descriptions, it is assumed that some of the older wastes are MW.

The Sugar Bunker Dump accepted waste for surface storage as early as January 1960, and began burying waste by January 1961 when Pit No. 1 (later designated T01B) was opened. In 1965, trenches T03A, T06B, and T01A began receiving LLW. Trench T04B began receiving waste in 1970 and was the principal Area 5 disposal unit from 1970 through 1972. Trench T02B opened in July 1972. Trenches T05 and T06A were operating by 1974 and appeared to be mostly full by mid-1976. These eight shallow disposal trenches all received LLW and waste that contained hazardous constituents or suspected hazardous constituents. All eight trenches were operationally closed by 1978. 


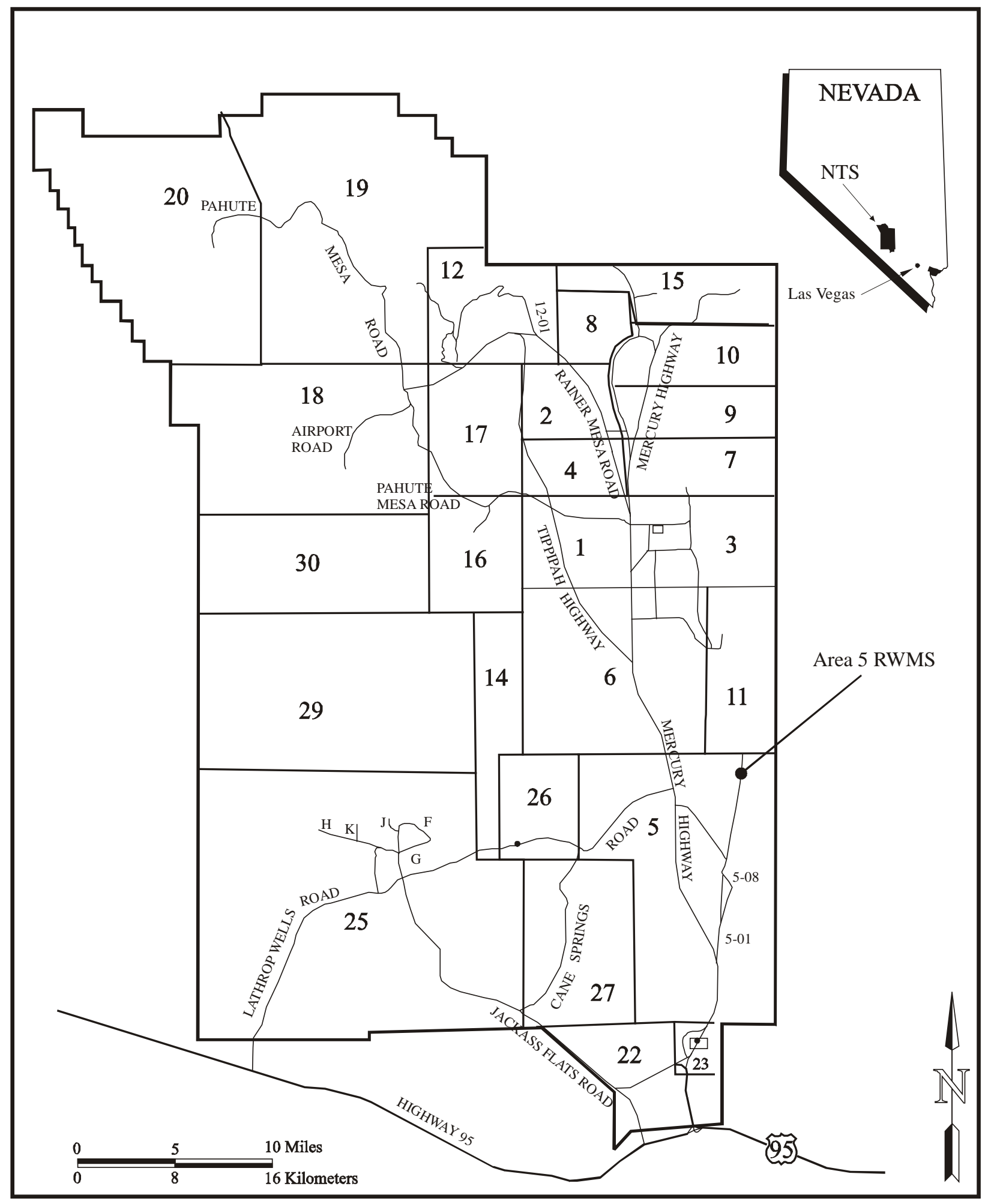

Figure A-2. Area 5 Radioactive Waste Management Site LOCATION MAP 


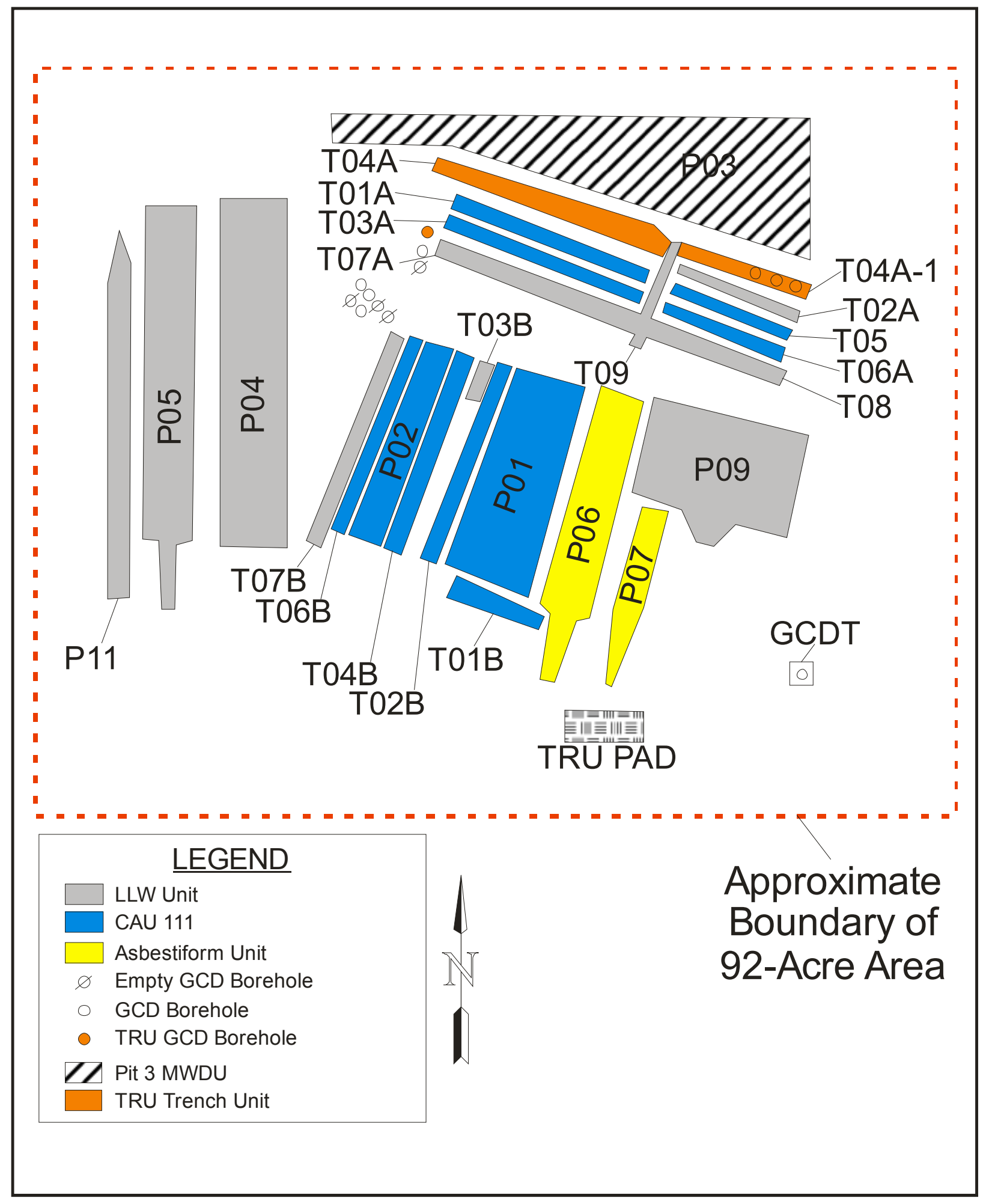

Figure A-3. 92-ACre Area Disposal Units 
Trench T04A began receiving waste in March 1969. In 1986, approximately 2.6 pounds of TRU waste from Rocky Flats were inadvertently disposed in trench T04A. In 1995, when trench T09 was excavated perpendicular to the T04A trench, the east end of the trench was renamed T04A-1. The T04A and T04A-1 trenches were operationally closed in August 1995.

DOE established the NTS Waste Management Program in 1978, and the Area 5 RWMS was established on a 732-acre site incorporating the existing Sugar Bunker Dump waste cells in the southeast corner. The site began receiving LLW from offsite DOE generators. Trench T07B was opened by 1978 and received waste from Rocky Flats. There is no evidence in the disposal records of hazardous material being disposed in T07B.

Between 1978 and September 26, 1988 (when DOE O 5820.2A, "Radioactive Waste Management” [now replaced with DOE O 435.1] was promulgated), P01, P02, and T07B were filled and operationally closed.

In 1981, the Greater Confinement Disposal Test (GCDT) borehole was equipped to evaluate the feasibility of disposing high specific activity waste at the NTS. The waste included encapsulated radioactive sources, strontium-90 in thermoelectric generators, and drums of radioisotopes. Nine 120 -ft boreholes were drilled around the GCDT, at locations 10, 16, and $22 \mathrm{ft}$ from the GCDT, and were equipped with instruments to monitor soil temperature, soil moisture, and migration of tracers or radionuclides. The GCDT project ran for over 7 years and provided information on potential for waste migration. The GCDT was then operationally closed.

Based on results of the GCDT, 12 GCD boreholes were drilled for operational use in 1984. Three of the boreholes were drilled in the base of T04A-1. The rest were drilled from ground surface outside of the trenches. The GCD boreholes are generally $10 \mathrm{ft}$ in diameter, $120 \mathrm{ft}$ deep, and unlined, except for $10 \mathrm{ft}$ of corrugated metal surface casing. Between 1984 and 1989, 8 of the 12 GCD boreholes were used to dispose of "special case" or "orphan" wastes. These are wastes that did not meet acceptance criteria for other facilities. They have subsequently been designated as high-specific-activity LLW (waste similar to Greater-than Class C), MW, TRU waste, and MTRU waste. Detailed inventories of waste and materials in the GCD boreholes are presented in Dickman (1989) and Chu and Bernard (1991).

Although the GCDT and the Area 5 RWMS monitoring data suggest burial in these boreholes was safe and effective, disposal of waste in GCD boreholes was discontinued in 1989 when the Nevada Division of Environmental Protection (NDEP) determined the boreholes to be Class IV injection wells, which are prohibited by EPA regulations and Nevada Administrative Code (NAC). Six GCD boreholes have been filled with waste to a depth of about $70 \mathrm{ft}$ below surface and operationally closed with backfill consisting of native soil. Two boreholes have received waste and remain open (although inactive), and four boreholes are empty. In 1993, EPA clarified that underground disposal of containerized radioactive waste in geologic repositories subject to the 40 CFR 191 standards does not constitute underground injection under the EPA's underground injection control program.

CAU 111 includes the following waste disposal units, which are all operationally closed: P01, P02, T01B, T02B, T04B, T06B, T01A, T03A, T05, and T06A. There are currently three active pits in the 92-Acre Area: P03, P06, and P09. P03 is the only active MWDU. P06 and P09 contain LLW. P06 accepts asbestiform LLW, and the bottom tier is used for disposal of thorium waste. Table A-8 summarizes the types of waste, operational status, and disposal volumes of the six closure units in the 92-Acre Area. 


\subsection{REgULATORY DRIVERS FOR CLOSURE}

The closure units must comply with the closure requirements of multiple regulations. All units must comply with the requirements set forth in DOE O 435.1. A final PA and CA must be developed for the closure of the entire Area 5 facility, including the expansion area north of the 92-Acre Area. Partial unit closures are allowed under DOE O 435.1. The current PA evaluated the closure of the facility at the assumed closure date of 2028 and demonstrated compliance with the performance objectives of DOE O 435.1. The PA evaluated the radionuclide inventory disposed in the cells after September 1988 and the forecasted inventory at closure. The current CA shows compliance for all waste in all disposal units, including pre- and post-1988 inventory and TRU waste. The PA and CA evaluated the facility performance for 1,000 years after closure assuming an evapotranspirative cover. An optimization was performed in fiscal year (FY) 2009 to determine a final cover thickness for the potential final closure cover design.

For the TRU waste inadvertently disposed in trench T04A, a SA has been performed. The SA shows that leaving the TRU waste in T04A will meet the performance objectives of 40 CFR 191. The SA shows that the alternative of excavating, certifying, and shipping the TRU waste elsewhere would involve unacceptable risk to workers and prohibitive cost.

As discussed in Section 1.2, a PA was performed for GCD boreholes 1, 2, 3 and 4, which contain TRU waste. DOE approved the PA. The $70 \mathrm{ft}$ of backfill over the waste in the boreholes provides assurance that the transport of radionuclides from the waste zone to the ground surface through plant uptake and animal burrowing activity will not be possible. Minimal quantities of waste could reach the surface through diffusion and advective transport associated with upward flux. As demonstrated in the PA, the releases over a 10,000-year post-closure period under a wetter and cooler climate regime will be negligible.

The radionuclide component of waste in the legacy CAU 111 units has been evaluated under the CA and found to meet the performance objective of a 100-mrem/yr dose, as discussed in Section 1.2. The radionuclide inventories in the Pit 3 MWDU and the Asbestiform Unit have been evaluated under the PA. The hazardous component of waste in all units will perform similarly to the radionuclide component that has been modeled. Since the transport behavior of hazardous metals and volatiles is similar to that of particulate and volatile radionuclides, there is assurance that there will not be any significant release of hazardous materials to the surface soils from the waste zones through the predominantly upward pathways of bioturbation and upward liquid flux.

\subsection{WASTE INVENTORY}

Waste inventory has been established through historical studies conducted to support compliance assessments under DOE O 435.1 and closure and monitoring activities. Uncertainty of the inventory was addressed by bounding estimates in the original PA and probabilistically in the 2005 addendum. As discussed in Section 1.0, the inventory is insensitive as far as the long-term performance of the facility is concerned because of limited releases of waste from the waste zones to the atmosphere above the disposal cells. Therefore, further effort to refine the inventory estimates in order to further reduce their uncertainty is not warranted. The following sections discuss historical disposal practices and provide information regarding data archives and data warehousing efforts. They also describe the GoldSim ${ }^{\circledR}$ inventory model developed for the Area 5 RWMS, which is updated annually as new waste disposal occurs. 
Table A-8. 92-Acre Area Waste Unit Status

\begin{tabular}{|c|c|c|c|c|c|c|c|c|}
\hline $\begin{array}{c}\text { DISPOSAL } \\
\text { UNIT }\end{array}$ & $\begin{array}{c}\text { FIRST } \\
\text { RECORD }\end{array}$ & $\begin{array}{c}\text { LAST } \\
\text { RECORD }\end{array}$ & $\begin{array}{l}\text { RECORDED } \\
\text { VOLUME } \\
\left(\mathrm{FT}^{3}\right)^{\dagger}\end{array}$ & $\begin{array}{l}\text { CALCULATED } \\
\text { DISPOSAL } \\
\text { UNIT VOLUME } \\
\text { (FILLED WITH } \\
\text { WASTE) } \\
\left(\text { FT }^{3}\right)^{\ddagger} \\
\end{array}$ & $\begin{array}{l}\text { RECORDED/ } \\
\text { CALCULATED } \\
\text { VOLUME }\end{array}$ & CURIES & $\begin{array}{l}\text { OPERATIONAL } \\
\text { STATUS }\end{array}$ & CONTENTS \\
\hline P01 & 20-Sep-78 & 25-Apr-85 & $1.6 \mathrm{E}+06$ & $3.8 \mathrm{E}+06$ & 0.42 & $2.6 \mathrm{E}+06$ & $\begin{array}{l}\text { Operationally } \\
\text { Closed }\end{array}$ & $\begin{array}{l}\text { LLW, lead, lead shielding, barium } \\
\text { source, organic solvents }\end{array}$ \\
\hline $\mathrm{P} 02$ & 18-Dec-84 & 19-Nov-95 & $8.9 \mathrm{E}+05$ & $1.3 \mathrm{E}+06$ & 0.68 & $2.0 \mathrm{E}+05$ & $\begin{array}{l}\text { Operationally } \\
\text { Closed }\end{array}$ & $\begin{array}{l}\text { LLW, lead, lead shielding, barium } \\
\text { source, organic solvents }\end{array}$ \\
\hline $\mathrm{P} 03$ & 18-Sep-85 & 17-Jul-08 & $1.5 \mathrm{E}+06$ & $3.0 \mathrm{E}+06$ & 0.49 & $1.4 \mathrm{E}+05$ & Active & MW (RCRA permitted) \\
\hline P04 & 14-Jun-88 & 25-Oct-95 & $2.5 \mathrm{E}+06$ & $3.3 \mathrm{E}+06$ & 0.75 & $1.2 \mathrm{E}+05$ & $\begin{array}{l}\text { Operationally } \\
\text { Closed }\end{array}$ & LLW \\
\hline P05 & 15-May-95 & 27-Sep-07 & $2.2 \mathrm{E}+06$ & $4.1 \mathrm{E}+06$ & 0.53 & $2.2 \mathrm{E}+06$ & $\begin{array}{l}\text { Operationally } \\
\text { Closed }\end{array}$ & LLW \\
\hline P06/P06A & 3-Dec-04 & 7-Feb-08 & $5.0 \mathrm{E}+05$ & $1.5 \mathrm{E}+06$ & 0.33 & $4.0 \mathrm{E}+02$ & Active & Asbestiform LLW \\
\hline P07 & 15-Sep-97 & 10-Feb-03 & $1.8 \mathrm{E}+05$ & $4.4 \mathrm{E}+05$ & 0.41 & $6.6 \mathrm{E}+01$ & $\begin{array}{l}\text { Operationally } \\
\text { Closed }\end{array}$ & Asbestiform LLW \\
\hline P09 & 10-Dec-03 & 9-Oct-07 & $2.7 \mathrm{E}+05$ & $5.9 \mathrm{E}+05$ & 0.46 & $2.9 \mathrm{E}+04$ & Active & LLW \\
\hline P11 & 27-Jan-04 & 5-Apr-05 & $1.2 \mathrm{E}+05$ & $2.2 \mathrm{E}+05$ & 0.54 & $2.9 \mathrm{E}+04$ & $\begin{array}{l}\text { Operationally } \\
\text { Closed }\end{array}$ & LLW \\
\hline T01B & 7-Jan-61 & 29-Jun-65 & $2.9 \mathrm{E}+04$ & $2.6 \mathrm{E}+05$ & 0.11 & $8.9 \mathrm{E}+00$ & $\begin{array}{l}\text { Operationally } \\
\text { Closed }\end{array}$ & $\begin{array}{l}\text { LLW, lead bricks, lead shielding, } \\
\text { cadmium, chromium, mercury, } \\
\text { organic solvents }\end{array}$ \\
\hline T02B & 5-Jul-72 & 5-May-78 & $3.5 \mathrm{E}+04$ & $4.7 \mathrm{E}+05$ & 0.07 & $2.8 \mathrm{E}+00$ & $\begin{array}{l}\text { Operationally } \\
\text { Closed }\end{array}$ & LLW, organic solvents, lead \\
\hline T03B & 2-Mar-92 & 10-Sep-92 & $2.4 \mathrm{E}+04$ & $5.4 \mathrm{E}+04$ & 0.44 & $2.1 \mathrm{E}+00$ & $\begin{array}{l}\text { Operationally } \\
\text { Closed }\end{array}$ & LLW \\
\hline Т04B & 25-Feb-70 & 29-Nov-77 & $5.1 \mathrm{E}+04$ & $4.9 \mathrm{E}+05$ & 0.10 & $3.3 \mathrm{E}+06$ & $\begin{array}{l}\text { Operationally } \\
\text { Closed }\end{array}$ & $\begin{array}{l}\text { LLW, organic solvents, lead } \\
\text { shielding, mercury }\end{array}$ \\
\hline т06B & 1-Jul-65 & 25-May-70 & $1.7 \mathrm{E}+05$ & $3.7 \mathrm{E}+05$ & 0.45 & $1.3 \mathrm{E}+04$ & $\begin{array}{l}\text { Operationally } \\
\text { Closed }\end{array}$ & $\begin{array}{l}\text { LLW, laboratory waste containing } \\
\text { lead, cadmium and mercury, organic } \\
\text { solvents, lead bricks }\end{array}$ \\
\hline T07B & 16-May-78 & 22-Sep-78 & $1.1 \mathrm{E}+05$ & $4.3 \mathrm{E}+05$ & 0.27 & $5.3 \mathrm{E}+05$ & $\begin{array}{l}\text { Operationally } \\
\text { Closed }\end{array}$ & LLW \\
\hline
\end{tabular}


Table A-8. 92-Acre Area Waste Unit Status (Continued)

\begin{tabular}{|c|c|c|c|c|c|c|c|c|}
\hline $\begin{array}{c}\text { DISPOSAL } \\
\text { UNIT }\end{array}$ & $\begin{array}{c}\text { FIRST } \\
\text { RECORD }\end{array}$ & $\begin{array}{c}\text { LAST } \\
\text { RECORD }\end{array}$ & $\begin{array}{l}\text { RECORDED } \\
\text { VOLUME } \\
\left(\mathrm{FT}^{3}\right)^{\dagger}\end{array}$ & $\begin{array}{c}\text { CALCULATED } \\
\text { DISPOSAL } \\
\text { UNIT VOLUME } \\
\text { (FILLED WITH } \\
\text { WASTE) } \\
{\left(\mathrm{FT}^{3}\right)^{\ddagger}}^{\ddagger}\end{array}$ & $\begin{array}{l}\text { RECORDED/ } \\
\text { CALCULATED } \\
\text { VOLUME }\end{array}$ & CURIES & $\begin{array}{c}\text { OPERATIONAL } \\
\text { STATUS }\end{array}$ & CONTENTS \\
\hline T01A & $10-O c t-65$ & 19-May-76 & $1.8 \mathrm{E}+04$ & $3.6 \mathrm{E}+05$ & 0.05 & $2.1 \mathrm{E}+03$ & $\begin{array}{l}\text { Operationally } \\
\text { Closed }\end{array}$ & LLW, lead \\
\hline T02A & 7-Nov-88 & 22-Jul-93 & $6.0 \mathrm{E}+04$ & $1.3 \mathrm{E}+05$ & 0.46 & $1.4 \mathrm{E}+02$ & $\begin{array}{l}\text { Operationally } \\
\text { Closed }\end{array}$ & LLW \\
\hline T03A & 26-Aug-69 & 10-Dec-76 & $2.5 E+04$ & $3.7 \mathrm{E}+05$ & 0.07 & $2.0 \mathrm{E}+03$ & $\begin{array}{l}\text { Operationally } \\
\text { Closed }\end{array}$ & $\begin{array}{l}\text { LLW, organic solvents, chromium, } \\
\text { lead }\end{array}$ \\
\hline T04A/T04A-1 & 12-Dec-85 & 3-Aug-95 & $6.4 \mathrm{E}+04$ & $3.6 \mathrm{E}+05$ & 0.17 & $1.7 \mathrm{E}+03$ & $\begin{array}{l}\text { Operationally } \\
\text { Closed }\end{array}$ & $\begin{array}{l}\text { LLW, TRU ( } 2.6 \text { pounds TRU } \\
\text { inadvertently disposed in } 1986 \text { ) }\end{array}$ \\
\hline T05/T06A & 31-Jan-74 & 31-Jan-74 & $2.0 \mathrm{E}+03$ & $4.6 \mathrm{E}+05$ & 0.00 & $0.0 \mathrm{E}+00$ & $\begin{array}{l}\text { Operationally } \\
\text { Closed }\end{array}$ & LLW, organic solvents \\
\hline T07A/T08 & 14-May-01 & 23-Apr-03 & $6.6 \mathrm{E}+05$ & $1.0 \mathrm{E}+06$ & 0.64 & $2.5 \mathrm{E}+03$ & $\begin{array}{l}\text { Operationally } \\
\text { Closed }\end{array}$ & LLW \\
\hline T09 & 3-Aug-95 & 31-Oct-02 & $4.4 \mathrm{E}+04$ & $1.2 \mathrm{E}+05$ & 0.37 & $7.1 \mathrm{E}+04$ & $\begin{array}{l}\text { Operationally } \\
\text { Closed }\end{array}$ & LLW \\
\hline Unknown & 30-Jun-70 & 15-Nov-90 & $1.8 \mathrm{E}+06$ & - & - & $2.7 \mathrm{E}+05$ & - & - \\
\hline Total & 7-Jan-61 & 18-Dec-07 & $1.4 \mathrm{E}+07$ & $2.3 E+07$ & $0.58^{\S}$ & $9.5 E+06$ & & \\
\hline GCDT & 15-Dec-83 & 6-Mar-84 & $5.8 \mathrm{E}+02^{\S}$ & $4.3 \mathrm{E}+03$ & 0.14 & $5.3 \mathrm{E}+05$ & $\begin{array}{l}\text { Operationally } \\
\text { Closed }\end{array}$ & LLW \\
\hline GCD-01C & 1984 & 1984 & $1.4 \mathrm{E}+03^{\S}$ & $4.3 \mathrm{E}+03$ & 0.32 & $1.8 \mathrm{E}+02$ & $\begin{array}{l}\text { Operationally } \\
\text { Closed }\end{array}$ & $\begin{array}{l}\text { TRU, lithium deuteride (may contain } \\
\text { melted high explosives, lead, } \\
\text { mercury) }\end{array}$ \\
\hline GCD-02C & 1984 & 1984 & $9.8 \mathrm{E}+02^{\S}$ & $5.6 \mathrm{E}+03$ & 0.18 & $1.0 \mathrm{E}+03$ & $\begin{array}{l}\text { Operationally } \\
\text { Closed }\end{array}$ & $\begin{array}{l}\text { TRU (may contain melted high } \\
\text { explosives, lead, mercury) }\end{array}$ \\
\hline GCD-03C & 1984 & 1984 & $1.9 \mathrm{E}+02^{\S}$ & $5.6 \mathrm{E}+03$ & 0.03 & $1.1 \mathrm{E}+02$ & $\begin{array}{l}\text { Operationally } \\
\text { Closed }\end{array}$ & $\begin{array}{l}\text { TRU (may contain melted high } \\
\text { explosives, lead, mercury) }\end{array}$ \\
\hline GCD-04C & 19-Jul-85 & 14-Jan-87 & $1.3 \mathrm{E}+03^{\dagger}$ & $4.3 \mathrm{E}+03$ & 0.31 & $6.8 \mathrm{E}+00$ & $\begin{array}{l}\text { Operationally } \\
\text { Closed }\end{array}$ & LLW, TRU, lithium hydride \\
\hline GCD-05U & 26-Jun-85 & 9-Apr-87 & $3.2 \mathrm{E}+03^{\dagger}$ & $4.3 \mathrm{E}+03$ & 0.74 & $2.1 \mathrm{E}+06$ & $\begin{array}{l}\text { Operationally } \\
\text { Closed }\end{array}$ & LLW \\
\hline
\end{tabular}


Table A-8. 92-Acre Area Waste Unit Status (Continued)

\begin{tabular}{|c|c|c|c|c|c|c|c|c|}
\hline $\begin{array}{c}\text { DISPOSAL } \\
\text { UNIT }\end{array}$ & $\begin{array}{c}\text { FIRST } \\
\text { RECORD }\end{array}$ & $\begin{array}{c}\text { LAST } \\
\text { RECORD }\end{array}$ & $\begin{array}{c}\text { RECORDED } \\
\text { VOLUME } \\
\left(\text { FT }^{3}\right)^{\dagger} \\
\end{array}$ & $\begin{array}{c}\text { CALCULATED } \\
\text { DISPOSAL } \\
\text { UNIT VOLUME } \\
\text { (FILLED WITH } \\
\text { WASTE) } \\
{\left(\mathrm{FT}^{3}\right)^{\ddagger}}^{\text {(a) }} \\
\end{array}$ & $\begin{array}{c}\text { RECORDED/ } \\
\text { CALCULATED } \\
\text { VOLUME }\end{array}$ & CURIES & $\begin{array}{c}\text { OPERATIONAL } \\
\text { STATUS } \\
\end{array}$ & CONTENTS \\
\hline GCD-06U & 16-Jul-86 & 20-Feb-87 & $2.4 \mathrm{E}+02^{\dagger}$ & $4.3 \mathrm{E}+03$ & 0.06 & $6.5 \mathrm{E}+03$ & $\begin{array}{l}\text { Closed to } \\
\text { waste, not yet } \\
\text { backfilled }\end{array}$ & LLW \\
\hline GCD-07C & 7-Jul-89 & 7-Jul-89 & $3.8 \mathrm{E}+02^{\dagger}$ & $4.3 \mathrm{E}+03$ & 0.09 & $1.9 \mathrm{E}+00$ & $\begin{array}{l}\text { Closed to } \\
\text { waste, not yet } \\
\text { backfilled }\end{array}$ & LLW \\
\hline GCD-10U & 11-Dec-87 & 27-Oct-89 & $2.0 \mathrm{E}+03^{\dagger}$ & $5.9 \mathrm{E}+03$ & 0.35 & $6.0 \mathrm{E}+05$ & $\begin{array}{l}\text { Operationally } \\
\text { Closed }\end{array}$ & LLW \\
\hline GCD Total & 23-Feb-83 & 27-Oct-89 & $1.0 \mathrm{E}+04$ & $4.3 \mathrm{E}+04$ & 0.24 & $3.2 \mathrm{E}+06$ & & \\
\hline
\end{tabular}

${ }^{\dagger}$ - Source: Table 10 of Denton et al., 2008

‡ - Calculated by Area 5 Inventory GoldSim model, Version 2.022

$\S$ - Source: Chu and Bernard, 1991

$\mathrm{ft}^{3}$ : cubic foot (feet)

GCD: Greater Confinement Disposal

GCDT: Greater Confinement Disposal Test

LLW: low-level waste

MW: mixed waste

RCRA: Resource Conservation and Recovery Act

TRU: transuranic 
Waste has been accepted at Area 5 since January 1960 and placed in disposal cells since January 1961. The oldest records for the original Sugar Bunker Dump generally show load origin, a brief description of the material and containers, estimated radioactivity, and date of disposal. When necessary, a specific trench or pit can be inferred from burial date and history of the development of the disposal features. The original paper records were scanned into a digital format, and then archived. The quality of some of these scanned images is poor, and some of the data are difficult to read. There is also uncertainty as to the completeness of the scanned records.

The Radioactive Waste Management (RWM) System was developed in 1988. The RWM System tabulated basic information on a per-shipment basis for waste received from August 13, 1974, through 1992. The RWM System had design flaws, typical in early databases due to limited programming capabilities, which resulted in inconsistent entries, incomplete records, and the creation of orphan records due to poor interrelationships between the master tables and detail tables. Users of the system could modify, delete, and add data in sub-tables without changing, deleting, or adding records to the master table.

After September 30, 1992, the Low-Level Waste Information System (LWIS) Oracle application was implemented. Data in this database were stored in a single record, indexed by package. The level of characterization and burial location detail improved. Burial location was provided based on an alphanumeric grid. The tier and location within the cell were recorded. The Oracle relational database structure of the LWIS prevented some of the quality and orphan data problems that plagued the RWM System. The web applications used by generators and waste operations personnel to input data also had built-in validation features to reduce errors in the database. Bar-coding and scanning systems were implemented to facilitate package tracking.

In May 1997, the Nevada Test Site Waste Acceptance Criteria system, an enhancement to LWIS, was implemented and accepts multiple waste profiles, includes more detailed information on waste form and treatment, and is currently in use. To document and improve the accuracy of the historic waste inventory for 1961 through 1978 and make the information more usable, several historic tracking systems, including paper records and scanned records, were reviewed and cross-checked. The data were incorporated into one searchable spreadsheet. Chemical hazards were not routinely profiled before landfill regulations and RCRA were implemented; therefore, the presence of hazardous constituents and suspected hazardous constituents, and consequently the characterization of some waste as being potential MW, was inferred from general descriptions, historic photographs, and other sources. The early RWM System database covering disposal from the mid-1970s through 1992 was also checked and cross-checked with other documentation to attempt to verify locations, volumes, and characteristics of waste disposed.

Table A-8 provides information on waste buried from 1961 through December 2004. These data are from three sources: scanned paper records, the RWM System database, and the LWIS database, with slightly overlapping periods of record.

\subsection{HAZARDOUS WASTE INVENTORY}

The hazardous waste inventory has been compiled from available records for all units that contain hazardous materials. Pit 3 and the Asbestiform Unit are permitted units with well-kept records. Waste in the CAU 111 units and the GCD boreholes contain hazardous materials of uncertain quantities. Estimates of hazardous components in these units are discussed below. 


\subsubsection{CAU 111 Disposal Units}

The CAU 111 disposal units were in operation prior to the implementation of a detailed record keeping system. Table A-9 presents the Sugar Bunker Dump designations, if applicable. Waste was typically disposed in bulk form or containerized in plastic bags, steel drums, and cardboard, plywood, or steel boxes. Waste stream descriptions are limited. Typical waste stream descriptions include laundry wastes, laboratory wastes, scrap metal, contaminated soil, personal protective equipment, and samples.

Other waste streams include farm wastes from the historic EPA Farm operations, which may have included animal wastes. Many records do not indicate the exact location where the waste was disposed. Analytical waste profiling focused primarily on radioactivity but typically only stated a total curie estimate without identifying specific radionuclides. From process knowledge and general waste descriptions, it can be inferred that some wastes contain hazardous constituents. Approximately 40 percent of available records indicate hazardous constituents may be present; however, the amount of hazardous constituents present in these wastes is unknown.

Past laboratory operations at the NTS have typically included the use of organic solvents. Waste streams denoting laboratory wastes are therefore assumed to contain an unknown amount of organic solvent. Solvents may include those typically found in laboratories (e.g., toluene, acetone, trichloroethylene, benzene, and carbon tetrachloride). Lead shielding, loose lead, and lead bricks have also been noted in disposal records. Lead shielding is assumed to be present from any record denoting the disposal of radioactive sources.

Table A-10 presents the known or suspected hazardous constituents present in each CAU 111 disposal unit. Constituents consist primarily of organic solvents and lead. Estimated waste volumes presented in Table A-8 are based on disposal unit dimensions and disposal practices. A radionuclide inventory was developed based on historic characterization data, assumptions regarding the isotopic composition of uncharacterized waste streams, and estimated waste volumes as described in the PA (BN, 2006). The approach is consistent with the methods used to estimate the pre-1998 inventory and accounts for 100 percent of the estimated waste volumes.

Table A-9. CAU 111 Cell Designations

\begin{tabular}{|c|c||}
\hline CURRENT DESIGNATION & SUGAR BUNKER DESIGNATION \\
\hline \hline P01 & none \\
\hline P02 & none \\
\hline T01B & Pit No.1 \\
\hline T02B & UF \\
\hline T04B & UD \\
\hline T06B & UA \\
\hline T01A & CA \\
\hline T03A & CC \\
\hline T05 & N-HA \\
\hline T06A & S-HA \\
\hline
\end{tabular}


Table A-10. CAU 111 Hazardous Waste Constituents

\begin{tabular}{|c|c|}
\hline DISPOSAL UNIT & KNOWN OR SUSPECTED HAZARDOUS CONSTITUENTS \\
\hline P01 & lead, lead shielding, a barium source, organic solvents \\
\hline P02 & lead, lead shielding, a barium source, organic solvents \\
\hline T01B & $\begin{array}{c}\text { lead bricks, lead shielding, cadmium, chromium, mercury, organic } \\
\text { solvents }\end{array}$ \\
\hline T02B & organic solvents, lead \\
\hline T04B & organic solvents, lead shielding, mercury \\
\hline Т06B & $\begin{array}{c}\text { laboratory wastes containing lead, cadmium and mercury, organic } \\
\text { solvents, lead bricks }\end{array}$ \\
\hline T01A & lead \\
\hline T03A & organic solvents, chromium, lead \\
\hline T05 & organic solvents \\
\hline T06A & organic solvents \\
\hline
\end{tabular}

\subsubsection{GCD Boreholes}

Known hazardous waste in the GCD boreholes includes an estimated 60.5 kilograms of lithium hydride in borehole 4 and 45.0 kilograms of lithium deuteride in borehole 1 (Chu and Bernard, 1991). These exhibit the hazardous characteristic of reactivity. Some nuclear weapons accident residue (NWAR) waste in boreholes 1, 2, and 3 may contain melted high explosives in the waste matrix. Lead and mercury are also believed to be present in the NWAR waste matrix, which exhibit characteristics of toxicity.

\subsection{INVENTORY MODEL}

The first attempt to compile the radionuclide inventory in the Area 5 RWMS disposal cells occurred in the early 1990s to support the development of the Area 5 RWMS PA and CA documents (Shott et al., 1998; BN, 2001b). The second major review and revision to the inventory estimates occurred in 2004 during the preparation of the addendum to the Area 5 PA (BN, 2006).

To support the addendum, an inventory model was developed using GoldSim ${ }^{\circledR}$ software. The model includes all historic records and accounts for uncertainty of the inventories and volumes of the disposed waste. The Area 5 Inventory Model (currently at version v2.014) estimates the inventory of radionuclides disposed in various disposal units at the RWMS.

The model is implemented in the probabilistic GoldSim ${ }^{\circledR}$ modeling platform, which allows estimation of inventory uncertainty by Monte Carlo simulation. Inventory radioactive decay and ingrowth during the operational period are also handled by native GoldSim ${ }^{\circledR}$ routines for solution of the Bateman equations. Model input data, data sources, assumptions, and methods are documented in notes, comments, hyperlinks, and graphics included within the model (BN, 2006). 
Inventory records are maintained in three sources: the waste management logbook, the Waste Management Division (WMD) database, and the LWIS. The waste management logbook is a paper record summarizing disposal at the Area 5 RWMS from 1960 until 1978. Beginning in 1976, some disposal records were entered into the WMD, an electronic database in use until 1993. From 1993 until the present, the LWIS has been in use. In addition to the database records, original records sent by the generator, survey records, and receipt records are maintained in an electronic imaging system. Records of disposals regulated under DOE O 435.1 are maintained in the WMD and LWIS. The data sources have numerous limitations (Shott et al., 1998). Records before 1994 are especially uncertain. Known problems include:

- Waste characterization before 1994 is not complete. Important radionuclides may not have been reported. In early records, radionuclides may not have been identified, and disposal is simply recorded as "curies." Some records indicate mixtures of radionuclides, such as mixed fission products (MFPs), depleted uranium, enriched uranium, plutonium, or plutonium scrap codes (PU51, PU52, or PU57).

- Inventory records are incomplete. Not all disposals were entered into waste management records. This problem occurs more commonly for older records.

- The pre-1993 relational database tables are not completely populated with data. Consequently, some records in different database tables cannot be linked and retrieved in queries. Detailed review of the database and supporting records in FY 2004 has reduced this problem significantly. It is estimated that there are approximately 3,300 packages that cannot be associated with an inventory. This represents less than 1 percent of the package records.

- The pre-1993 database radionuclide quantity data are recorded by shipment rather than by container. If containers within a shipment were sent to different disposal units, the total shipment inventory would have been recorded as disposed in each unit. This may cause multiple counting of some inventories.

\subsection{INVENTORY REVISIONS}

The 1998 PA added the activity of a limited list of fission products based on the activity recorded in the database as MFPs or disposed as strontium-90 or cesium-137. The fission product scaling factors were estimated from a literature source of fission yields for fast neutron fission of plutonium-239. The current model assigns activity to individual fission products based on the activity of only MFP or gross activity disposed. The list of radionuclides included and their scaling factors are based on an estimate of the radionuclide composition of the NTS underground testing areas.

The 1998 PA estimated the inventory of unreported uranium isotopes by assuming an isotopic mixture for each generator. The model assumes uranium-238 and uranium-235 disposed before FY 1994 were depleted and enriched uranium, respectively. Enriched uranium is stochastically divided for each FY into low and high enrichment fractions. The level of enrichment in each category (i.e., depleted, low enrichment, high enrichment) is selected randomly for each FY. The isotopic composition of each mixture is based on a published empirical relationship between specific activity and enrichment for the gaseous diffusion process (DOE, 2004). In addition to corrections for uranium isotopes, scaling factors for fission product and transuranic contamination from recycled uranium are estimated from data provided by waste generators. 
The 1998 PA estimated the inventory of unreported radionuclides in weapons-grade plutonium disposed as PU52, an American National Standards Institute (ANSI) plutonium scrap code (ANSI, 1987). The current model performs similar revisions, but also includes calculations for PU51 and PU57. The inventory of plutonium-239 disposed before FY 1994 is assumed to represent the activity of PU52 weapons-grade plutonium, and corrections are made for other transuranic radionuclides expected to be present.

Important model inputs are set up as pdfs representing uncertainty. Input pdfs are repeatedly sampled and propagated through the model to produce a distribution of model results. The model output distributions are well represented by lognormal distributions and are entered into the Area 5 RWMS GoldSim ${ }^{\circledR}$ model as lognormal distributions with the geometric mean and standard deviation of the inventory model outputs. The assumptions made in the inventory model include:

- Waste disposed from October 1, 1988, through September 30, 2028, is regulated by DOE 0 435.1. There is no official closure date for the site. The 2028 closure date is an arbitrary assumption based on an assumed 50-year operational period starting in 1978, when the Area 5 RWMS opened to offsite generators.

- Uncertainty in disposed waste inventories is poorly known. Therefore, waste uncertainty is represented by what is believed to be a conservative distribution. The annual sums of radionuclide activity disposed after October 1, 1988, are assumed to be the median of a lognormal distribution. The 99th percentile of the distribution is assumed to be equal to ten times the median (geometric standard deviation $=2.69$ ).

- Waste disposed before FY 1994 is assumed to be incompletely characterized. Radionuclide disposal rates before FY 1994 are corrected for unreported radionuclides. Activity disposed as gross activity or MFP activity is scaled to estimate individual radionuclide activities by assuming that the mixture has the same radionuclide composition as the NTS underground testing areas (Bowen et al., 2001). The reported gross activity or fission product activity is assumed to be the activity of cesium-137, and all other fission product and activation product activity is scaled from cesium-137. The activity of uranium-238 and uranium-235 disposed before FY 1994 is assumed to be the activity of depleted and enriched uranium, respectively. Scaling factors for other uranium isotopes are based on a published relationship between specific activity and enrichment of uranium for the gaseous diffusion process (DOE, 2004). Scaling factors for minor contaminants in uranium are estimated from data provided by generators. Plutonium disposed as PU51, PU52, and PU57 are assigned individual radionuclide activities based on isotopic composition of standard plutonium scrap codes (ANSI, 1987) and typical values expected for weapons-grade plutonium.

- The WMD database does not include data for all disposed wastes. Some waste shipments were not recorded in the databases. Some database tables are not fully populated, and waste inventories cannot be retrieved by queries. The potential missing waste has been estimated by subtracting the volume of disposed waste retrieved from the databases from the physical volume of filled waste disposal units. The missing volume has been added to the inventory assuming it has the mean concentration of disposed waste. This correction is applied to pre-1988 waste only.

- The volume of future waste is based on estimates provided by waste generators. The concentration of waste in future FYs is assumed to be equal to randomly selected concentrations from past FYs. 


\subsection{STATE THE PROBLEM (STEP 1)}

Step 1 of the DQO process describes the problem to be studied and develops a CSM to gain a sufficient understanding in defining the problem.

\subsection{Problem Statement}

The problem statement for the 92-Acre Area is, "Is the site sufficiently characterized to provide the input data necessary to evaluate corrective action alternatives without the collection of additional data?”

\subsection{Conceptual Site Model}

The CSM describes the site performance (source term, releases, fate, and transport). It reflects the best interpretation of available site information and describes the most probable scenario for current conditions at the site. The CSM is based on historical documentation, personnel interviews, site process knowledge, and characterization, modeling, and monitoring data.

The CSM for the 92-Acre Area demonstrates that migration of contaminants is not occurring and that buried waste is not creating a dose to NTS workers. The CSM also demonstrates that the buried waste does not pose a risk to future MOPs and the environment. Characterization, modeling, and monitoring data have demonstrated this, and the geology, meteorology, surface water, vadose zone, groundwater, vegetation, wildlife, soil gas, natural hazards, subsidence, and air quality of the site have been studied extensively to support the CSM. The CSM that is implemented in the facility assessments is described in Section 3.2.2, following the site characteristics discussed below.

\subsubsection{Site Characteristics}

\subsubsection{Geography}

The Area 5 RWMS is located in the northern part of the Frenchman Flat hydrographic basin, at the juncture of three coalescing alluvial fan systems (Snyder et al., 1995). Frenchman Flat is a roughly circular, topographically closed basin bounded by the Massachusetts Mountains on the north, the Buried Hills and Ranger Mountains on the east and southeast, Mount Salyer on the west, and Mercury Ridge and Red Mountain on the south. The Area 5 RWMS is at an elevation of approximately 3,180 to 3,200 ft above mean sea level.

\subsubsection{Geology}

The mountain ranges surrounding Frenchman Flat consist primarily of Tertiary volcanic rocks and underlying Paleozoic sedimentary rocks. Erosion of the mountain ranges has resulted in deposition of a significant thickness of alluvium. Thickness of alluvium in Frenchman Flat ranges between 0 and 4,900 ft. Basalt flows are interbedded in the alluvium in the northern part of Frenchman Flat, approximately $900 \mathrm{ft}$ below the ground surface. The alluvium is underlain by interbedded Tertiary ash-flow and ash-fall tuff estimated to be over 3,900 ft thick (BN, 2005e). 
Principal faults in Frenchman Flat are the Cane Spring Fault and the Rock Valley Fault. The Cane Spring Fault is a left-lateral, strike-slip fault that strikes southwest to northeast in the northern part of Frenchman Flat, 4 mi northwest of the Area 5 RWMS. The Rock Valley Fault is a left-lateral, strike-slip fault with a minor dip-slip component (down to the north) that strikes southwest to northeast in the southern part of Frenchman Flat, about $5.5 \mathrm{mi}$ south of the Area 5 RWMS. Both of these faults are active and responsible for earthquakes within the recent past.

\subsubsection{Meteorology}

The NTS is located between the northern boundary of the Mojave Desert and the southern limits of the Great Basin Desert. This "transitional desert" is considered to be typical of either the dry mid-latitude or dry subtropical climatic zones. The climate is arid and characterized by low precipitation, a large diurnal temperature range, a large evaporation rate, and moderate to strong winds (BN, 2005f).

The average annual precipitation from 1963 to 2004 at the Well 5B meteorological station, $4 \mathrm{mi}$ south of the Area 5 RWMS, is 4.92 inches (in.). Potential evapotranspiration (PET) is a measure of the exchange of water and heat between the earth's surface and the atmosphere and an important component of the water balance calculation used to evaluate the potential for precipitation to infiltrate and percolate to the waste cells. PET at the NTS is high because of the large incident solar radiation and high average wind speeds, and occurs at a potential, or energy-limiting, rate. Average annual PET from 1995 through 2004 was 60.2 in., many times the average precipitation rate.

The open and sparsely vegetated Frenchman Flat basin is windy and enhances evaporation rates. In 2004, the average daily wind speed was 5.8 miles per hour (mph), and the maximum gust measured was $45.6 \mathrm{mph}$. Winds are primarily from the southwest during spring and summer months and from the north during winter months. Wind speeds tend to be greatest in spring.

\subsubsection{Surface Water}

No permanent surface water is present within Frenchman Flat, with the exception of small artificial impoundments and Cane Spring, which issues from a perched aquifer recharged from infiltration through fractures in the nearby mountains. Cane Spring is approximately $9 \mathrm{mi}$ southwest of the Area 5 RWMS. Alluvial fans within Frenchman Flat are cut by numerous arroyos that drain storm runoff to the playa. Water that accumulates on the playa typically evaporates or infiltrates, or both, within a short period of time. Frenchman Playa is approximately $4 \mathrm{mi}$ southeast of the Area 5 RWMS.

Flood analyses for the 25-year and 100-year storm events have been conducted for the Area 5 RWMS (Schmeltzer et al., 1993). Although the southwest corner of the Area 5 RWMS is within the 100-year floodplain, most of the 92-Acre Area is outside the floodplain delineation. Disposal units within the Area 5 RWMS are protected from offsite flooding events by a RCRA-compliant berm and channel system capable of conveying flood flows from a 25-year, 24-hour storm event. 


\subsubsection{Vadose Zone}

Several studies and models have been completed to characterize the stratigraphy and physical properties of the unsaturated zone in Area 5, the physical properties of the existing operational covers, and the potential for movement of water through the vadose zone (Albright et al., 1994; Blout et al., 1995; BN, 2005b; BN, 2005c; BN, 2005e; REECo, 1993a; REECo, 1993b).

Time-domain reflectometry (TDR) data from automated waste cover monitoring systems provide direct measurement of moisture content in soil. Measured volumetric soil water content at the P03 and P05 floor sensors has consistently been approximately 10 percent, which indicates that moisture has not migrated more than $4 \mathrm{ft}$ below the waste (BN, 2005f).

The Area 5 Weighing Lysimeter Facility, located approximately 1,300 ft southwest of the Area 5 RWMS, consists of two precision weighing lysimeters. One lysimeter is vegetated with native plant species at the approximate density of the surrounding desert. The other is not vegetated to simulate the bare operational waste covers at the Area 5 RWMS. Each of the weighing lysimeters is instrumented with TDR probes to measure volumetric soil-water content at depths ranging from 4 to 67 in. Due to transpiration, the vegetated lysimeter is significantly drier than the bare-soil lysimeter. Wetting fronts at the vegetated lysimeter have not exceeded $4 \mathrm{ft}$ in depth except in the spring of 2005, in comparison with the bare-soil lysimeter, where moisture reached the base of the lysimeter at $6.6 \mathrm{ft}$ and began to pond.

Model simulations calibrated to the weighing lysimeter data set indicate that once vegetated, drainage through a cover is essentially eliminated (Desotell et al., 2006). Climate and vegetation strongly influence the movement of water in the near-surface alluvium (upper $6.5 \mathrm{ft}$ ). Except for periods following precipitation events, water content in the near-surface region is low. Below this region is a zone where steady upward movement of water is occurring, primarily via evaporation (Tyler et al., 1996). This zone extends to depths as great as 10 to $131 \mathrm{ft}$. Below this zone, water potential measurements indicate the existence of a static zone between approximately 131 and $295 \mathrm{ft}$ below ground surface (Shott et al., 1998). In this static zone, essentially no vertical liquid flow is currently occurring. Below this static zone, flow is downward, due to gravity.

In the unlikely event contaminants migrate below the static region to where vertical gravitational flow is possible, movement to the groundwater would be extremely slow. Conservative median modeling estimates of the time it would take water to move from beneath the static region (approximately $300 \mathrm{ft}$ below ground surface) to the groundwater (approximately $720 \mathrm{ft}$ below ground surface) are in excess of 50,000 years (Shott et al., 1998). Under model assumptions, there is a 99 percent probability that the time would exceed 30,000 years (Shott et al., 1998).

\subsubsection{Groundwater}

Frenchman Flat is in the Ash Meadows sub-basin (Laczniak et al., 1996) of the Death Valley Regional Flow System, a major hydrologic subdivision of southern Great Basin. Groundwater primarily flows through the lower carbonate-rock aquifer and discharges along a line of springs in Ash Meadows. Water levels within the lower carbonate-rock aquifer indicate that the gradient is nearly flat (less than $1.6 \mathrm{ft}$ per mi), and calculated groundwater flow velocities have generally been less than $0.5 \mathrm{ft}$ per year. The depth to the static water level in Frenchman Flat ranges from $690 \mathrm{ft}$ near the central playa to more than 1,150 ft at the northern end of the valley. 
Groundwater from the uppermost aquifer (Laczniak et al., 1996) is sampled semiannually. Water samples collected from three wells are analyzed for radioactive and nonradioactive constituents. Groundwater monitoring data are presented in detail in the annual groundwater monitoring data report (BN, 2005g). All groundwater sampling data to date indicate that the groundwater in the uppermost aquifer is unaffected by RWMS or DOE weapons testing activities.

The potential for groundwater quality impacts from the Area 5 RWMS waste storage is low because vertical movement of percolating water is limited by many factors including climate and geology. Except for short-term events, evapotranspiration is much higher than precipitation. There is insignificant stormwater runoff, there has been no apparent recharge in the immediate vicinity, and there are no known potential conduits deeper than the GCD boreholes that could speed transmission of potential leachate to deeper strata.

\subsubsection{Vegetation (Flora) and Wildlife (Fauna)}

The nature and distribution of plants and animals and their ecological interactions are of interest both as agents of contaminant transport and as potential receivers of contaminants. They have a complex role in potential transport of water and radioactive particles through soil landfill covers.

The type, maturity, and density of vegetation affect the potential for evapotranspiration, soil erosion, and rainwater infiltration (Hunter and Medica, 1989; Ostler et al., 2000). Rooting depth is tied to soil moisture availability. Shrubland species at the Area 5 RWMS have shallow root systems, and observed root depths are generally less than $6.6 \mathrm{ft}$ (Foxx et al., 1984a; 1984b; Hansen and Ostler, 2003). The potential for plants to enhance downward movement of water towards buried waste is offset by their use of water to live and grow. Decomposition of roots provides channels for water and vapor and may enhance infiltration and percolation through the rooting depth, but plants remove water from the soil, store it in biomass, and transpire it back to the atmosphere. Plant evapotranspiration minimizes potential water transport through the cover, and the plant canopy and roots help control erosion of the surface by wind and rain.

Because plant roots absorb radionuclides from soil water, draw radionuclides up into leafy parts of the plant, and potentially release some to the atmosphere via transpiration, vegetation can also be a factor in the movement of radionuclides in the near surface. Biota monitoring has mainly focused on sampling vegetation for tritium due to its high mobility as tritiated water. Vegetation from on and near waste covers, as well as vegetation from control areas far from waste covers, is usually sampled in mid-summer. Plant water is extracted from the vegetation samples by room temperature vacuum distillation and analyzed by liquid scintillation for tritium. If tritium concentrations in vegetation are exceedingly high, or if animal burrows on or near waste covers are observed in significant numbers, wild animals and soil from animal burrows may be sampled. Vegetation sampling may be limited year to year, depending on rainfall and waste cover operations during operational closure. Traces of tritium have been found in plant tissue.

Fauna have a potential role in transport of radioactive contaminants through burrowing and the food chain. Fauna within the Mojave Desert plant communities at Frenchman Flat are diverse. Ants and termites are the most numerous burrowing animals on the NTS (O'Farrell and Emery, 1976). Vertebrates are less numerous and diverse and include game and burrowing species. Both small and large burrowing mammals are present in the areas of the Area 5 RWMS. Rodents are the most common of the mammalian species on the NTS (Allred et al., 1963). 
The depth of burrowing is tied to soil conditions and rooting depths. Most animals at the NTS burrow in the upper $10 \mathrm{ft}$ of soil. Termites have been known to excavate as deep as $20 \mathrm{ft}$; however, because roots are their primary food source, burrowing depths are also closely related to rooting depth (Cochran et al., 2001). Vertebrate animal burrows at the RWMS tend to be below shrubs. Most of the burrows are 2 to $4 \mathrm{in}$. in diameter and extend approximately $1 \mathrm{ft}$ below ground surface.

\subsubsection{Soil Gas}

Monitoring of tritium concentrations in soil gas at multiple depths over time provides key data for evaluating the rate of vertical migration of radionuclides. Gas-phase tritium monitoring has been conducted via soil-gas sampling at GCD-05U since 1990. This disposal unit has a large tritium inventory (2.2 million curies at time of disposal) and is instrumented with two strings of nine soil-gas sampling ports buried at depths ranging from 10 to $120 \mathrm{ft}$ below surface. Tritium sampling at GCD-05U provides a direct measure of tritium migration from waste packages with time due to degradation of waste containers and the natural transport processes of advection and diffusion. Results from 1990 through 2004 indicate that soil-gas tritium concentrations have gradually increased at depths between 50 and $120 \mathrm{ft}$, but vertical migration is extremely slow.

\subsubsection{Natural Hazards and Subsidence}

Subsidence is expected to occur as waste and cover fill materials settle through time. Differential settling, especially across disposal feature margins, can cause cracks at ground surface, which could provide vertical migration pathways for water, vapor, and mobile contaminants. Depressions, which can retain water after rainstorms, allow more water to infiltrate and more plants to grow on the landfill covers. Large-volume groundwater withdrawals could also cause regional subsidence as the alluvial aquifer is dewatered, should groundwater pumping increase substantially in the future.

Many factors affect potential subsidence of the landfill covers, including structural integrity of containers, how containers were packed into units, weight of stacked containers and soil covers, void space within and around containers, and compaction of soil covers. Subsidence monitoring is conducted monthly at all disposal units.

Natural hazards that may affect the disposal areas include seismic activity and flooding. While these natural and incidental hazards are unpredictable, studies have been done to determine the relative risk of these hazards impacting the disposal sites, and measures have been implemented to reduce the risk of containment failure. Active faults nearest the Area 5 RWMS are within the Rock Valley fault system (O’Leary, 1996). These faults are over $3 \mathrm{mi}$ from the facility. Effects of future seismic events have been judged to not significantly impact the waste isolation performance of the Area 5 disposal facility (BN, 2006).

Three watersheds make up the drainage area that could impact the Area 5 RWMS. The southwest corner of the Area 5 RWMS is within a 100-year flood hazard zone. This zone is defined to have 0.01 percent probability that a flood with a depth of flow greater than $1 \mathrm{ft}$ could occur within any given year. Other parts of the Area 5 RWMS are within an area referred to as Zone X, a flood-hazard designation that corresponds to areas outside of the 100-year flood hazard zone. Sheet flow resulting from a 100-year, 6-hour precipitation event is anticipated to be less than $1 \mathrm{ft}$ deep (Schmeltzer et al., 1993). In the mid-1990s new channels and berms were designed and built. The berm system is adequate to handle a 25-year, 24-hour storm. 


\subsubsection{Air Quality}

Air monitoring is conducted to confirm that RWMS activities do not result in significant radionuclide concentrations above background. Air quality results are summarized in the annual Waste Management Monitoring Report (BN, 2005f). The tritium concentration in the air near the RWMS, compared to background concentrations at the NTS, is an indicator of how well the waste disposal cells are mitigating migration of volatile radionuclides from waste cells. Tritium concentrations at the Area 5 RWMS are less than the DOE Derived Concentration Guide (DCG) for tritium. According to DOE O 5400.5, "Radiation Protection of the Public and the Environment," the DCG is the concentration of a radionuclide in the air that could be inhaled for 1 year and not exceed the DOE radiation standard of $100 \mathrm{mrem} / \mathrm{yr}$ committed effective dose equivalent to the public (DOE, 1993).

Air particulate samples are collected weekly from monitoring stations near the RWMS and are screened for gross alpha and gross beta activity to provide early detection of any changes. Monthly composites of filters from each sampling location are analyzed for americium, plutonium, and gamma emitters. Air particulate monitoring data indicate that radionuclide concentrations in air at the RWMS are not above those of other nearby stations. The concentrations of all the analytes in samples from the RWMS are similar to concentrations elsewhere at the NTS.

Ionizing radiation from both natural and man-made sources is measured quarterly through a network of thermoluminescent dosimeters. Data collected from 1998 through 2004 indicate that direct radiation exposure at the Area 5 RWMS is low. Levels at all the sites were below 1.8 milliroentgens per day ( $\mathrm{mR} /$ day). The average exposure rate at background NTS locations is $0.30 \mathrm{mR} /$ day (BN, 2005f).

\subsubsection{Facility Assessments Conceptual Model}

The following discussion of the conceptual model is a summary from the second addendum to the PA (BN, 2006). Further details, including the implementation of the conceptual model in GoldSim $^{\circledR}$ and the analyses performed to identify the sensitivities, are included in the PA. The 1998 PA model of unsaturated flow in the vadose zone was developed to understand liquid fluxes capable of transporting radionuclides. The model, based primarily on observed water potential and chloride profiles, hypothesized four regions of liquid flow in the vadose zone (Figure A-4). Zone boundaries are approximate and may vary from location to location within Frenchman Flat. In Zone I, a near-surface zone approximately $115 \mathrm{ft}$ thick, the water potential indicates a potential for upward liquid flux. Zone II, occurring from approximately 115 to $295 \mathrm{ft}$, is a static region with negligible liquid flux. Zone III, an intermediate region with downward liquid fluxes driven by gravity, occurs from approximately $295 \mathrm{ft}$ to within a few inches of the saturated zone. The final region, Zone IV, which is a few inches thick, is a transitional zone between the vadose zone and the saturated zone where water potential and flow are negligible. 


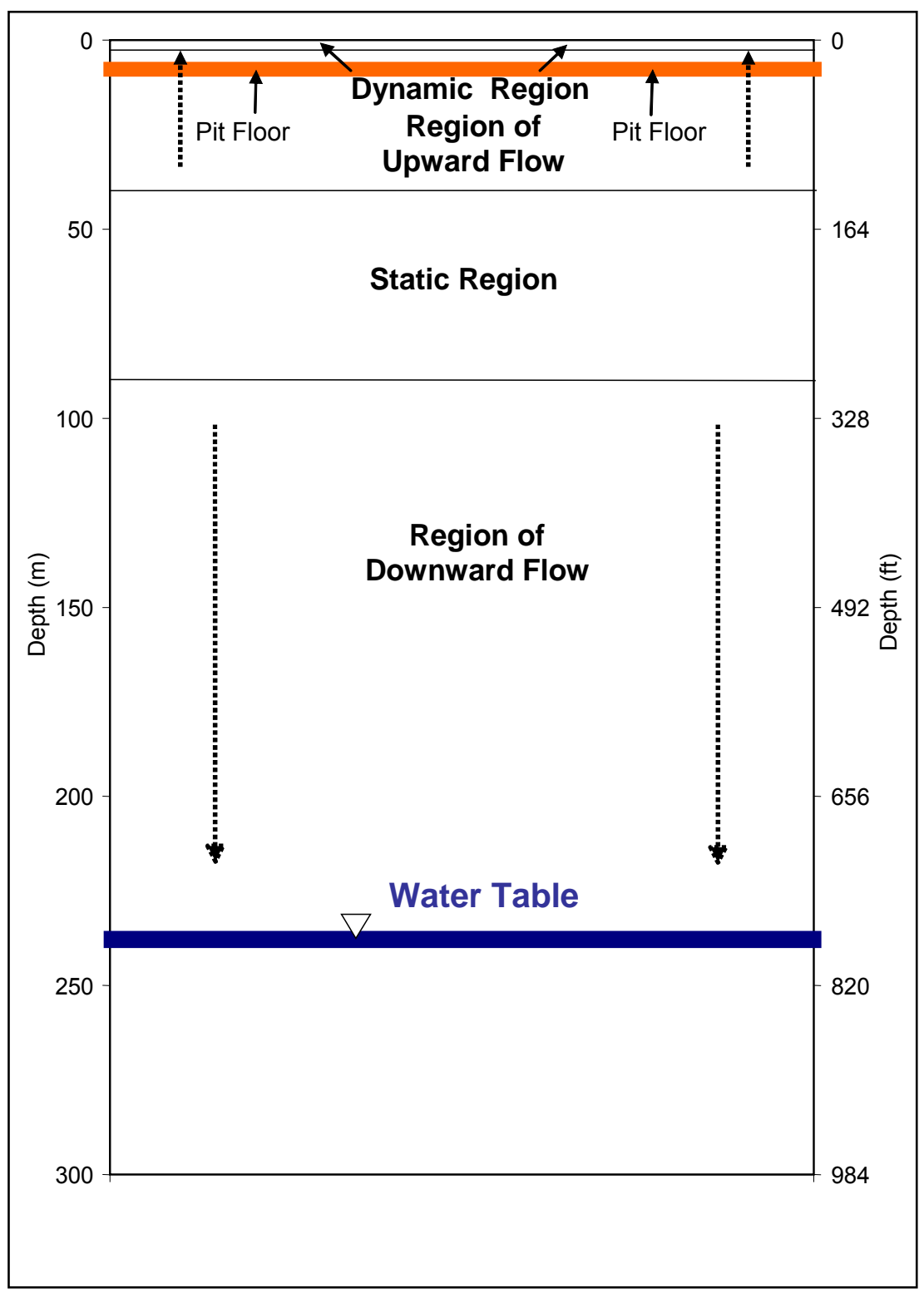

Dynamic Region: Magnitude and direction of liquid fluxes are variable and determined by episodic infiltration, evapotranspiration, and processes of biotic transport. The no-flux boundary is located at mean depth of $6 \mathrm{ft}$.

Zone I, Region of Slow Upward Flow: Region where the combination of low precipitation and high potential evapotranspiration leads to a dry zone, inducing upward flow of pore water in the unsaturated zone from as deep as about $100 \mathrm{ft}$. Mean upward flux is $0.004 \mathrm{~mm} / \mathrm{yr}$.

Waste zone located in region of upward flow.

Zone II, Static Region: Region of no vertical liquid flow (balance of matric suction and gravitational forces). The thickness and the depth below the surface of this region changes with the physical/textural properties of alluvium and in situ water content.

Zone III, Region of Slow Downward Flow: Region of steady downward flow (increased water content allows downward drainage). Water in the vadose zone is currently recharging the water table most likely infiltrated during past pluvial climate cycles.

There is no aerially distributed recharge to the groundwater table under current conditions.

\section{Figure A-4. PA Model of UnSATURATEd Flow in the Vadose Zone}


Zone I includes a dynamic region in the upper few feet of the vadose zone where the water potential gradient periodically reverses as precipitation infiltrates and is returned to the atmosphere by evapotranspiration. A strong upward potential for flow is maintained in Zone I by the roots of xeric desert plants. Although there is a potential for upward flow in Zone I, the soil is normally so dry that liquid water advection is very slow. In the very near-surface, where plant roots maintain low soil moisture content, upward water movement occurs predominantly in the vapor phase (and through plant roots), and the upward advection of soluble radionuclides may become negligible. The boundary where upward liquid advection rates approach zero is referred to as the no-flux boundary (NFB) in the PA model.

The large accumulation of chloride in Zone I below $6.6 \mathrm{ft}$ indicates that transient infiltration events are impeded above this depth and returned to the atmosphere by evapotranspiration. Assuming a constant atmospheric chloride source and downward liquid advection, the observed near-surface chloride accumulation below the root zone is estimated to require from 10,000 to 15,000 years to form, which corresponds with the end of the last pluvial period, approximately 8,000 to 15,000 years ago (Tyler et al., 1996; Walvoord et al., 2002a).

The chloride accumulated throughout the entire profile at pilot wells UE5PW-1 and UE5PW-3 suggests that infiltration at these locations has not reached the water table for 95,000 to 110,000 years (Tyler et al., 1996). The chloride profile at UE5PW-2 suggests that the sub-root zone chloride bulge was flushed from this profile at some time before 15,000 years ago, indicating that spatially variable recharge occurred during an earlier pluvial period. The chloride profiles in the vadose zone near the Area 5 RWMS suggest that recharge through the alluvium ended after the last pluvial period when the climate became drier and woodlands were replaced by more xeric desert shrubs.

The 1998 PA estimated upward liquid flux in Zone I using a process model. The estimated flux, $5 \times 10^{-6}$ millimeters per year (mm/yr), was so low that upward liquid advection of radionuclides was not included in the 1998 PA release and transport model. Diffusion of radionuclides in the liquid phase was considered as an alternative upward release pathway, but was assumed to be negligible at the low water contents in the near-surface based on theoretical considerations and literature reports. Although upward liquid advection and diffusion were included in the $1998 \mathrm{PA}$ conceptual model, their rates were assumed to be so low as to be negligible, and quantitative values were not included in the release and transport mathematical model.

\subsubsection{Recent Deep Vadose Zone Research and Development Results}

The understanding of how matric potential and chloride profiles develop in thick desert vadose zones has advanced since the 1998 PA. Although conditions in thick vadose zones appear to be stable over long periods, the upward liquid flux in Zone I and the downward liquid flux in Zone III suggest that the system cannot be at steady-state. Previous interpretations of the observed profiles had conceptual inconsistencies. Upward flow in Zone I and downward flow in Zone III cannot be maintained unless there is a water source in Zone II. If the source of water in Zone II is transient surface infiltration, the near-surface chloride accumulation is not expected. The chloride accumulation suggests that recharge is not occurring. However, purely physical models (i.e., without plants) that assume no recharge cannot simulate the large negative matric potentials observed in the near-surface. 
Walvoord et al. (2002b) have developed and tested the Deep Arid System Hydrodynamic (DASH) model for thick desert vadose zones that supports the 1998 PA conceptual model and resolves apparent inconsistencies between the observed water gradients and chloride profiles. The DASH conceptual model assumes a constant, strongly negative matric potential maintained below the root zone by desert vegetation, a mean annual geothermal temperature gradient, and allows water vapor movement driven by temperature (thermal vapor flux) and matric potential (isothermal vapor flux). Implementing this model with the finite element heat and mass transfer (FEHM) model, Walvoord et al. (2002b) have shown that matric potential and chloride profiles similar to those observed at the Area 5 RWMS can be maintained at equilibrium. The model identifies water vapor driven upward from the water table by the geothermal temperature gradient as the probable source of water to the deep vadose zone. The water fluxes are extremely small, and the profiles are not currently at equilibrium. Zones II and III are most likely still draining infiltration that occurred during prior pluvial periods.

Using surface boundary conditions for infiltration and root-zone matric potentials based on a 110,000-year paleoclimate reconstruction for southern Nevada, Walvoord et al. (2002a) were able to simulate matric potential and chloride profiles observed at the Area 5 RWMS pilot wells, UE5PW-1, UE5PW-2, and UE5PW-3. Sub-root zone upward liquid fluxes were estimated to range from $2 \times 10^{-5}$ to $1 \times 10^{-3} \mathrm{~mm} / \mathrm{yr}$ under the current climatic conditions. The hydraulic response time, the time required for an e-fold $\left(1-\mathrm{e}^{-1}\right)$ change in matric potential from the initial to steady-state profile, was estimated to be 300,000 years for Frenchman Flat, again suggesting that the pilot well profiles are not at equilibrium, but drying very slowly.

\subsubsection{Recent Shallow Vadose Zone Research and Development Results}

A key assumption of the DASH model is that plants maintain a large negative matric potential in the root zone and extract all infiltrating water. Andraski (1997) has investigated water movement in the upper $16 \mathrm{ft}$ of the vadose zone in the Amargosa Desert. On a vegetated native soil plot, no evidence of water accumulation or percolation below $3.3 \mathrm{ft}$ was observed over a five-year period. Non-vegetated plots showed a small increase in water storage and percolation to depths of $6 \mathrm{ft}$.

The Area 5 weighing lysimeter facility, located approximately 1,300 ft southwest of the Area 5 RWMS, has been continuously recording water storage in two 6.6-ft-deep precision weighing lysimeters since March 1994. One lysimeter has been revegetated with native plants, and the other is maintained bare. No increase in water storage has been observed for the vegetated lysimeter. Early increases in water content for the vegetated lysimeter were caused by irrigation performed to establish native plants. The bare lysimeter shows a slowly increasing trend in water storage. Although water has never been observed to drain from the bottom of either lysimeter, it is likely that a small fraction of infiltrating precipitation will eventually drain from the bare lysimeter (BN, 2005f).

Water content in the near-surface has also been monitored at the Area 5 RWMS since 1995. Water content monitoring began with neutron moisture measurements in boreholes at Pit 3 (P03). Beginning in 1998, automated water content monitoring systems using TDR probes were installed in the operational cover and floor of Pit 3 and Pit 5, in the cover of Pit 4, and outside the Area 5 RWMS near UE5PW-1. With the installation of the automated TDR system, neutron moisture logging has been discontinued. 
Automated TDR moisture content monitoring in the weighing lysimeter indicates that wetting fronts penetrate a short distance in the vegetated lysimeter before being evaporated. Wetting fronts, including some occurring during the particularly wet fall of 2004, are not observed to penetrate below $4.3 \mathrm{ft}$ in the vegetated lysimeter. Percolation to greater depths may occur in unvegetated areas, including operational covers at the Area 5 RWMS. Wetting fronts from the fall of 2004 have been observed to penetrate to a depth of $4.9 \mathrm{ft}$ at Pit 3 and Pit 4 (BN, 2005f). Monitoring systems installed below Pit 3 and Pit 5 continue to show constant water contents, indicating that no water has percolated through waste.

\subsubsection{Current Vadose Zone Conceptual Model}

The vadose zone conceptual model implemented in the Area 5 RWMS GoldSim ${ }^{\circledR}$ model is similar to the $1998 \mathrm{PA}$ model. The mathematical implementation of the model in the Area 5 RWMS GoldSim ${ }^{\circledR}$ model includes a number of refinements and additional detail for the shallow vadose zone. Both models assume Zone I has a potential for upward transport of soluble radionuclides by upward liquid advection and diffusion in the liquid phase. The 1998 PA assumed that the upward liquid flux and liquid diffusion rate were negligible in Zone I. The Area 5 RWMS GoldSim ${ }^{\circledR}$ model divides Zone I into two regions with different upward liquid fluxes. Above the NFB, assumed to be at a mean depth of $6.6 \mathrm{ft}$, upward liquid flux is assumed to be zero. Below the NFB, a pdf of upward liquid fluxes is assumed. Complete documentation of the vadose zone conceptual model is found in the Area 5 RWMS GoldSim ${ }^{\circledR}$ model and its references (BN, 2006).

Upward liquid fluxes cannot be directly measured under the dry conditions at the Area 5 RWMS. Since preparation of the 1998 PA, upward water fluxes ranging over nearly six orders of magnitude have been estimated by several different modeling methods. Water balance and stable isotope methods have produced the highest estimates ranging from 0.1 to $1 \mathrm{~mm} / \mathrm{yr}$ (Tyler et al., 1999). Physical models of liquid flow have produced lower estimates ranging from $5 \times 10^{-6}$ to $0.2 \mathrm{~mm} / \mathrm{yr}(\mathrm{BN}, 2001 \mathrm{~b}$; Shott et al., 1998). The Area 5 RWMS CA (BN, 2001b) and Area 3 RWMS PA/CA used a mean water flux (vapor and liquid flux) of $0.3 \mathrm{~mm} / \mathrm{yr}$ and $0.2 \mathrm{~mm} / \mathrm{yr}$, respectively, estimated using stable isotope methods (Chapman, 1995; 1997).

Although each of these methods has its advantages and disadvantages, the physical models are considered to give the most reliable estimates. The water balance and stable isotope methods are suspected to produce overestimates because they calculate average rates over long time intervals when rates were likely changing. The stable isotope method assumptions may also be violated as applied at the Area 5 RWMS (Wolfsberg and Stauffer, 2003). The physical model results are uncertain because of uncertainty in the unsaturated hydraulic conductivity at low moisture contents. Unsaturated hydraulic conductivities are difficult to measure at the low Area 5 moisture contents. Most past efforts to estimate upward liquid fluxes with physical models have used unsaturated hydraulic conductivities predicted from moisture retention data.

The simulations of Wolfsberg and Stauffer (2003) are assumed to be the best available estimate of upward liquid flux. Their simulations consider a full range of surface boundary conditions and material properties, including unsaturated hydraulic conductivities measured at expected water contents. The 32 realizations of upward liquid flux from the Wolfsberg and Stauffer (2003) simulations were used to develop an upward liquid flux pdf for the Area 5 RWMS GoldSim $^{\circledR}$ model. The development of the upward liquid flux pdf is documented in the Area 5 RWMS GoldSim ${ }^{\circledR}$ model and its references (BN, 2006). 


\subsubsection{Conclusions}

The Area 5 RWMS is well suited for the isolation and disposal of waste. The site is located in an access-controlled government facility many miles from residential populations. The site has a windy, arid climate. Average annual PET is 60.2 in., many times the average precipitation rate of 4.92 in. On an annual basis, even in wet, cool years, evaporative demand is high.

The site is far from surface waters. Surface runoff and run-on is insignificant, and engineered berms provide protection from a 25-year flood. Risks of significant earthquake hazards are low. Minor subsidence of the ground surface above the edges of waste containers and the margins of the cells is likely; however, this localized subsidence can be mitigated through monitoring and maintaining the covers to preclude cracks or depressions from allowing infiltration of rainwater. Plant evapotranspiration minimizes potential water transport through the cover, and the plant canopy and roots help control erosion of the surface by wind and rain.

The vadose zone below the waste cells has low water potentials, low unsaturated hydraulic conductivity rates, and ample water storage capacity. Therefore, the potential for significant downward transmission of water is extremely low. Below this zone, water potential measurements indicate the existence of a static zone where essentially no vertical liquid flow is currently occurring. Conservative modeling estimates suggest it would take more than 50,000 years for water to move from beneath the static region to the groundwater, which is over $700 \mathrm{ft}$ below ground surface. If water were to carry contaminants to the groundwater, water levels indicate that the gradient is nearly flat, and calculated groundwater flow velocities have generally been less than $0.5 \mathrm{ft}$ per year. Effectively, there is no groundwater pathway, and the potential for groundwater contamination from waste disposal activities at the Area 5 RWMS is negligible.

The majority of the waste inventory is LLW, and much of the LLW contains radionuclides that will decay significantly over the next several decades. Much of the radioactivity in the waste inventory is in relatively immobile forms, with the exception of tritium, a volatile radionuclide that can readily move with water.

The CSM indicates that contaminants are not readily released or transported. The waste acceptance criteria, packaging requirements, monitoring, climate characteristics, and other factors minimize the potential for release and transport of contaminants. Assessments and analyses indicate that the Area 5 RWMS will meet the DOE regulatory performance criteria for the 1,000-year compliance period. Predicted potential human exposures for various future potential land-use scenarios are negligible. 


\subsection{IDENTIFY THE GOAL OF THE STUDY (STEP 2)}

Step 2 of the DQO process identifies the questions the study will attempt to resolve and what actions may result. The goal of the study is to answer the following questions satisfactorily.

1. Do historical information and monitoring data adequately allow for the development and evaluation of corrective action alternatives? If so, then the corrective action alternatives will be developed and evaluated to identify the risks and costs associated with each.

2. If not, is it possible to develop such data? If the historical information and monitoring data do not adequately allow for the evaluation of corrective action alternatives, a sampling strategy and corresponding DQOs will be developed and presented to NDEP. 


\subsection{IDENTIFY INFORMATION INPUTS (STEP 3)}

Step 3 of the DQO process identifies the information needed to address the goals of the study.

\subsection{INFORMATION NEEDS}

All information needed to develop and evaluate corrective action alternatives is summarized below. These data have been collected in association with various studies and from modeling that has been conducted to support development of a closure strategy and monitoring programs. Corrective action alternatives in addition to those listed below may be developed; however, the data needs listed below are expected to encompass any additional alternatives that may be developed.

- Closure-in-place data needs

- CSM in sufficient detail that will allow for all pathways modeling to be completed

- Understanding of operational history (e.g., waste containerization, waste placement, disposal dates)

- Waste volumes and inventory (radiological and hazardous)

- Clean-closure data needs

- Sufficient information regarding waste volumes and inventory (radiological and hazardous) to estimate cost, worker dose, transportation risk, and dose to the public

- Identification of disposal capacity sufficient for the projected waste streams that will be generated in the event of a clean closure option

\subsection{SOURCES OF INFORMATION}

Existing information, such as historical documentation, personnel interviews, site process knowledge, site walk-downs, photographs, and previous field screening and analytical results, will be evaluated to determine if it supports the development and evaluation of alternatives. Several types of data will be used to develop corrective action alternatives.

\subsubsection{Qualitative Data}

Qualitative data identify or describe the characteristics or components of the site. The quality assurance/quality control (QA/QC) requirements are the least rigorous for qualitative data. This measurement of quality is typically assigned to historical information and data where QA/QC may be highly variable or not known. Professional judgment is often used to generate qualitative data.

Qualitative data used to support the development of corrective action alternatives are mainly limited to waste records prior to 1988. However, bounding estimates can be used to adequately account for any uncertainties without adversely affecting the decision-making process. This approach was implemented in the original PA for the Area 5 RWMS, in which bounding assumptions were made regarding the facility performance, and the inventory was evaluated to show compliance with the performance objectives of DOE O 435.1 for a compliance period of 10,000 years. The second addendum to the PA explicitly accounted for uncertainty by employing probabilistic modeling as described in Section 1.3. 


\subsubsection{Semi-quantitative Data}

Semi-quantitative data indirectly measure the quantity or amount of a characteristic or component. Inferences are drawn about the quantity or amount of a characteristic or component because a correlation has been shown to exist between the indirect measurement and the results from a quantitative measurement. The QA/QC requirements on semi-quantitative collection and measurement systems are high but may not be as rigorous as those for quantitative data.

Some semi-quantitative data have been used in various aspects of inventory development. Semi-quantitative data will also be used to estimate costs. Cost models using data from similar sites will be used to develop costs for each corrective action alternative.

\subsubsection{Quantitative Data}

Quantitative data measure the quantity or amount of a characteristic or component. These data require the highest level of QA/QC in collection and measurement systems because the intended use of the data is to resolve primary decisions and/or to verify that closure standards have been met. Laboratory analytical data are generally considered quantitative.

Quantitative measurements have been collected to support the development of the CSM and, during long-term monitoring, to determine whether contaminant migration has occurred. 


\subsection{DEFINE THE BOUNDARIES OF THE STUDY (STEP 4)}

Step 4 of the DQO process defines the target population of interest, specifies the spatial boundaries and time constraints of that population pertinent for decision making, and determines practical constraints on data collection.

\subsection{POPUlation OF INTEREST}

The populations of interest for which corrective actions will be developed include the following six units:

- LLW Unit

- CAU 111

- Asbestiform Unit

- $\quad$ Pit 3 MWDU

- $\quad$ TRU GCD Borehole Unit (CAU 207 [currently in CAU 5000])

- $\quad$ TRU Trench Unit

This includes waste inventory, waste constituents, and design parameters of the disposal cells. The population of interest will also include input parameters needed to develop costs and risks for corrective action alternatives, including identification of offsite disposal capacity, routes of transportation to the disposal capacity, definition of likely receptors along the route to disposal, population of potentially exposed workers, cost data, and the parameters described in the CSM.

\subsection{Time ConstrainTs}

The study data will be evaluated considering the length of time that will be required to develop corrective action alternatives and garner agreement from NDEP on the selection of a correct action alternative. In addition, a further time constraint will be the development of the Corrective Action Decision Document/Corrective Action Plan (CADD/CAP). Furthermore, if classified information must be accessed, additional time may be needed to complete the study.

The schedule will also take into account the time required to complete the closure process and prepare the Closure Report. The certificate of closure for the Pit 3 MWDU is due to NDEP by July 2011; therefore, the Closure Report will be prepared with this due date in mind. 


\subsection{DEVELOP THE ANALYTIC APPROACH (STEP 5)}

Step 5 of the DQO process develops a decision rule statement ("If..., then...") that defines the conditions under which possible alternative actions will be chosen.

\subsection{DECISION RULES}

Decision I:

- If it is determined that closure in place is the most feasible closure option, then a closure design will be developed ensuring that the performance criteria specified in DOE O 435.1 are met. It will be established that these criteria, while designed for radionuclide constituents, are also appropriate for hazardous constituents.

Decision II:

- If it is determined that clean closure is the most feasible closure option, then a closure plan will be prepared outlining the remediation plans that will include the development of an appropriate dose-based remediation standard.

\subsection{ACTION LEVELS}

Action levels for a closure-in-place alternative will be based on the landfill performance standards set forth in the various regulations that cover each of the six areas included in the 92-Acre Area.

The clean-closure alternative will rely upon the preliminary action levels for radiological contaminants. These action levels are based on the National Council on Radiation Protection and Measurements (NCRP)-recommended screening limits for construction, commercial, and industrial land-use scenarios (NCRP, 1999) scaled to $25 \mathrm{mrem} / \mathrm{yr}$ dose constraint (Murphy, 2004) and the generic guidelines for residual concentration of radionuclides in DOE O 5400.5 (DOE, 1993). Remaining radiological contamination will be posted per the NV/YMP RadCon Manual (NNSA/NSO, 2004).

\subsection{MeAsurement AND ANALYSIS SENSITIVITY}

Historical monitoring data have been of sufficient sensitivity to measure the worker dose and/or potential contaminant migration for the 92-Acre Area. These data were collected under a published DQO process as provided for in the Routine Radiological Environmental Monitoring Plan (BN, 2003).

To account for uncertainty in inventory development, bounding assumptions were used in the development of the model, as discussed in Section 1.3 of this document. Care has been taken to ensure these assumptions are reasonable, so as not to skew the evaluation of corrective action alternatives. 


\subsection{SPECIFY PERFORMANCE OR ACCEPTANCE CRITERIA (STEP 6)}

Step 6 of the DQO process specifies performance criteria for the decision rules. Setting tolerable limits on decision errors requires the planning team to weigh the relative effects of threats to human health and the environment, expenditure of resources, and the consequences of an incorrect decision. This section provides an assessment of the possible outcomes of DQO decisions and the impact of those outcomes if the decisions are in error.

In general, confidence in DQO decisions will be established qualitatively by the following:

- Developing CSMs

- Testing the validity of the CSMs based on an analysis of historical data

- Evaluating the quality of the data based on data quality indicator parameters

\subsection{DECISION ERRORS}

While additional corrective actions may be developed during the CADD/CAP process, the two bounding alternatives are closure in place and clean closure. A corrective action alternative has not been selected; however, to facilitate discussion of decision errors, closure in place will be defined as the baseline condition.

\subsubsection{False Rejection}

This error would mean deciding that the baseline condition is false when, in fact, it is true. This error means deciding that clean closure is the most advantageous option when closure in place is actually the preferable alternative. The possible consequences of this decision error are increased worker dose during removal, packaging, and transportation of waste; increased short-term risk to the public during transportation of waste; and increased cost. This error will be controlled by having a high degree of confidence in the data inputs such as waste inventory and the CSM. Assumptions that may be required to evaluate this alternative will be bounding, but reasonable enough to ensure the decision process is not adversely affected.

\subsubsection{False Acceptance}

This error would mean deciding that the baseline condition is true when, in fact, it is false. This error means deciding that closure in place is the most advantageous option when clean closure is actually the preferable alternative. The potential consequence is an increased risk to human health and the environment due to leaving the waste in place. This error will be controlled by having a high degree of confidence in the data inputs such as waste inventory and the CSM. Further, since most of these sites are currently controlled for radiological purposes and there is no proximal public receptor, the impact of this error is minimized. 


\subsection{DEVELOP THE PLAN FOR OBTAINING DATA (STEP 7)}

Step 7 of the DQO process provides the general approach for resolving the decisions. The pool of existing data will be used to resolve the decisions outlined above.

\subsection{Process Knowledge}

The historical operations associated with this site are well documented through multiple historical sources. Much of the operational information is based on semi-quantitative, and in some cases, quantitative data.

\subsection{WASTE INVENTORY RECORDS}

Much of this information has been gathered under compliance assessments of the Area 5 RWMS performed over a 20-year period. The available inventory will be used in the development of corrective action alternatives. Insensitivity of inventory to the results of the facility performance for the 1,000-year post-closure period supports the previous assertion made in Section 1.3 that waste inventory is sufficient to carry out the development of corrective action alternatives.

\subsection{Conceptual Site Model}

A large pool of quantitative data has been collected to accurately describe the CSM, thus providing the support needed to adequately quantify the risks and benefits of each of the proposed corrective action alternatives. 


\subsection{REFERENCES}

Albright, W., S. Tyler, J. Chapman, M. Miller, and R. Estrella, 1994. Area 5 Site Characterization Project Report FY 1994. DOE/NV/10845-T20. Desert Research Institute, Las Vegas, NV.

Allred, D. M., D. M. Beck, and C. D. Jorgensen, 1963. "Biotic Communities of the Nevada Test Site.” Brigham Young University Science Bulletin, Biological Series 2(2), No. 2.

American National Standards Institute, 1987. American National Standard for Nuclear Materials, Unirradiated Plutonium Scrap, Classification. ANSI N 15.10-1987. New York, NY.

Andraski, B. J., 1997. Soil-Water Movement Under Natural-Site and Waste-Site Conditions: A Multiple-Year Field Study in the Mojave Desert, Nevada. Water Resources Research. Vol. 33, No. 8, pp. 1,901-1,916.

ANSI, see American National Standards Institute.

Bechtel Nevada, 2001a. Addendum 1, Performance Assessment for the Area 5 Radioactive Waste Management Site at the Nevada Test Site, Nye County, Nevada: Reevaluation of the Chronic Inadvertent Human Intrusion Scenarios to Resolve the Disposal Authorization Statement Issues. DOE/NV/11718--176-ADD1. Las Vegas, NV.

Bechtel Nevada, 2001b. Composite Analysis for the Area 5 Radioactive Waste Management Site at the Nevada Test Site, Nye County, Nevada. DOE/NV--594. Las Vegas, NV.

Bechtel Nevada, 2001c. Addendum 1: Composite Analysis for the Area 5 Radioactive Waste Management Site at the Nevada Test Site, Nye County, Nevada. DOE/NV--594-ADD1. Las Vegas, NV.

Bechtel Nevada, 2003. Nevada Test Site Routine Radiological Environmental Monitoring Plan. DOE/NV/11718--804. Las Vegas, NV.

Bechtel Nevada, 2005a. Characterization Report: Operational Closure Covers for the Area 5 Radioactive Waste Management Sites at the Nevada Test Site. DOE/NV/11718--758. Las Vegas, NV.

Bechtel Nevada, 2005b. Hydrogeologic Characterization Data for the Area 5 Shallow Soil Trenches, Nevada, Nevada Test Site, Nye County, Nevada. DOE/NV/11718--1060. Las Vegas, NV.

Bechtel Nevada, 2005c. Site Characterization and Monitoring Data for the Area 5 Pilot Wells, Nevada Test Site, Nye County, Nevada. DOE/NV/11718--1067. Las Vegas, NV.

Bechtel Nevada, 2005d. Integrated Closure and Monitoring Plan for the Area 3 and Area 5 Radioactive Waste Management Sites at the Nevada Test Site. DOE/NV/11718--449REV2. Las Vegas, NV.

Bechtel Nevada, 2005e. A Hydrostratigraphic Model and Alternatives for the Groundwater Flow and Contaminant Transport Model of Corrective Action Unit 98: Frenchman Flat, Nye County, Nevada. DOE/NV/11718--1064. Las Vegas, NV. 
Bechtel Nevada, 2005f. Nevada Test Site 2004 Waste Management Monitoring Report, Area 3 and Area 5 Radioactive Waste Management Sites. BN-NTS-05-0025. Las Vegas, NV.

Bechtel Nevada, 2005g. Nevada Test Site 2004 Data Report: Groundwater Monitoring Program, Area 5 Radioactive Waste Management Site. DOE/NV/11718--1015. Las Vegas, NV.

Bechtel Nevada, 2006. Addendum 2 to the Performance Assessment of the Area 5 RWMS at the NTS, Nye County, Nevada Update of the Performance Assessment Methods and Results DOE/NV/11718--176ADD2. Las Vegas, NV.

BN, see Bechtel Nevada.

Blout, D. O., D. P. Hammermeister, K. A. Zukosky, and K. D. Donnelson, 1995. Site Characterization Data from the Area 5 Science Boreholes, Nevada Test Site, Nye County, Nevada. DOE/NV/11432-170. Reynolds Electrical and Engineering Company, Inc. Las Vegas, NV.

Bowen, S. M., D. L. Finnegan, J. L. Thompson, C. M. Miller, P. L. Baca, L. F. Olivas, G. C. Geoffrion, D. K. Smith, W. Goishi, B. E. Esser, J. W. Meadows, N. Namboodiri, and J. F. Wild, 2001. Nevada Test Site Radionuclide Inventory, 1951-1992. LA-13859-MS. Lawrence Livermore National Laboratory. Livermore, CA.

Chapman, J. B., 1995. "Evaporation Calculations at the Area 5 Radioactive Waste Management Site Based on Stable Isotope Data.” Letter report to T. Brown, Sandia National Laboratories. Desert Research Institute. Las Vegas, NV.

Chapman, J. B., 1997. "Evaporation Calculations at the Area 3 Waste Disposal Site Based on Stable Isotope Data.” Letter report to B. Moore, Waste Management Division, U.S. Department of Energy. Desert Research Institute. Las Vegas, NV.

Chu, M. S. Y., and E. A. Bernard, 1991. Waste Inventory and Preliminary Source Term Model for the Greater Confinement Disposal Site at the Nevada Test Site. SAND91-0170, UC-902. Sandia National Laboratories. Albuquerque, NM.

Cochran, J. R., W. E. Beyeler, D. A. Brosseau, L. H. Brush, T. J. Brown, B. Crowe, S. H. Conrad, P. A. Davis, T. Ehrhorn, T. Feeney, B. Fogleman, D. P. Gallegos, R. Haaker, E. Kalinina, L. L. Price, D. P. Thomas, and S. Wirth, 2001. Compliance Assessment Document for the Transuranic Wastes in the Greater Confinement Disposal Boreholes at the Nevada Test Site. Sandia National Laboratories, SAND2001-2977. Albuquerque, NM.

Colarusso, A., B. Crowe, and J. R. Cochran, 2003. "Completion of the Transuranic Greater Confinement Disposal Borehole Performance Assessment for the Nevada Test Site.” In: Proceedings of the Waste Management '03 Conference. Tucson, AZ.

Denton, R. C., M. R. Dolenc, and R. B. Hudson, 2008. An Evaluation of Historical Nevada Test Site Waste Records and an Interpretation of the Waste Volume. Las Vegas, NV.

Desotell, L. T., D. B., Hudson, V. Yucel, and J. T. Carilli, 2006. "Use of Long-Term Lysimeter Data in Support of Shallow Land Waste Disposal Cover Design.” In: Proceedings of the Waste Management '06 Conference. Tucson, AZ. 
Dickman, P. T., 1989. Greater Confinement Disposal Test at the Nevada Test Site, Final Technology Report, Rev. 1. Prepared by Science Applications International Corporation for Reynolds Electrical and Engineering Company, Inc.

DOE, see U.S. Department of Energy.

EPA, see U.S. Environmental Protection Agency.

Fiore, J., and R. Berube, 2002. Letter to Carl Gertz (DOE/NV) Subject: Compliance Assessment for the Transuranic Wastes in the Greater Confinement Disposal Boreholes at the Nevada Test Site. February 5, 2002.

Foxx, T. S., G. D. Tierney, and J. M. Williams, 1984a. Rooting Depths of Plants on Low-Level Waste Sites. LA-10253-MS. Los Alamos National Laboratory. Los Alamos, NM.

Foxx, T. S., G. D. Tierney, and J. M. Williams, 1984b. Rooting Depths of Plants as Related to Biological and Environmental Factors. LA-10254-MS. Los Alamos National Laboratory. Los Alamos, NM.

Hansen, D. J., and W. K. Ostler, 2003. Rooting Characteristics of Vegetation Near Radioactive Waste Management Sites 3 and 5 at the Nevada Test Site. DOE/NV/11718--595. Bechtel Nevada. Las Vegas, NV.

Hunter, R. B., and P. A. Medica, 1989. Status of the Flora and Fauna on the Nevada Test Site: Results of Continuing Basic Environmental Research, January through December 1987. DOE/NV/10630-2. Reynolds Electrical and Engineering Company, Inc.

Laczniak, R. J., J. C. Cole, D. A. Sawyer, and D. A. Trudeau, 1996. Summary of Hydrogeologic Controls on Ground-Water Flow at the Nevada Test Site, Nye County, Nevada. U.S. Geological Survey Water-Resources Investigations Report 96-4109.

Murphy, T., 2004. Nevada Division of Environmental Protection, Letter to R. M. Bangerter, Jr. (NNSA/NSO) entitled, "Review of Industrial Sites Project Document 'Guidance for Calculating Industrial Sites Project Remediation Goals for Radionuclides in Soil Using the Residual Radiation (RESRAD) Computer Code.’” November 19, 2004. Las Vegas, NV.

National Council on Radiation Protection and Measurements, 1999. Recommended Screening Limits for Contaminated Surface Soil and Review of Factors Relevant to Site-Specific Studies. NCRP Report No. 129. Washington, D.C.

NCRP, see National Council on Radiation Protection and Measurements.

O’Farrell, T. P., and L. A. Emery, 1976. Ecology of the Nevada Test Site: A Narrative Summary and Annotated Bibliography. NVO-167. National Technical Information Service Publication. Springfield, VA.

O’Leary, D. W., 1996. “Tectonic Significance of the Rock Valley Fault Zone, Nevada Test Site.” In: Whitney, J. W. (ed.) Seismotectonic Framework and Characterization of Faulting at Yucca Mountain, Nevada. U.S. Geological Survey. Denver, CO.

Ostler, W. K., D. J. Hansen, D. C. Anderson, and D. B. Hall, 2000. Classification of Vegetation on the Nevada Test Site. DOE/NV/11718--477. Bechtel Nevada. Las Vegas, NV.

REECo, see Reynolds Electrical and Engineering Company, Inc. 
Reynolds Electrical and Engineering Company, Inc., 1993a. Hydrogeologic Data for Existing Excavations at the Area 5 Radioactive Waste Management Site, Nevada Test Site, Nye County, Nevada. DOE/NV/11432-40.

Reynolds Electrical and Engineering Company, Inc., 1993b. Hydrogeologic Data for Science Trench Boreholes at the Area 5 Radioactive Waste Management Site, Nevada Test Site, Nye County, Nevada. DE-AC08-94-NV 11432 UC 721.

Schmeltzer, J. S., J. J. Miller, and D. L. Gustafson, 1993. Flood Assessment at the Area 5 Radioactive Waste Management Site and the Proposed Hazardous Waste Storage Unit, DOE, Nevada Test Site, Nye County, Nevada. Raytheon Services Nevada. Las Vegas, NV.

Shott, G. J., L. E. Barker, S. E. Rawlinson, M. J. Sully, and B. A. Moore, 1998. Performance Assessment of the Area 5 Radioactive Waste Management Site at the Nevada Test Site, Nye County, Nevada, Revision 2.1. DOE/NV/11718--176. Bechtel Nevada. Las Vegas, NV.

Shott, G. J., V. Yucel, and L. Desotell, 2008. Special Analysis of Transuranic Waste in Trench T04C at the Area 5 Radioactive Waste Management Site, Nevada Test Site, Nye County, Nevada, Revision 1.0. DOE/NV/25946--470. Las Vegas, NV.

Snyder, K. E., R. D. Van Remortel, D. L. Gustafson, H. E. Huckins-Gang, J. J. Miller, S. E. Rawlinson, and S. M. Parsons, 1995. Surficial Geology and Landscape Development in Northern Frenchman Flat, Area 5 Radioactive Waste Management Site, Nevada Test Site. Interim Summary and Soil Data Report. Raytheon Services Nevada. Las Vegas, NV.

Tyler, S. W., J. B. Chapman, S. H. Conrad, D. P. Hammermeister, D. O. Blout, J. J. Miller, M. J. Sully, and J. M. Ginanni, 1996. "Soil-Water Flux in the Southern Great Basin, United States: Temporal and Spatial Variations over the Last 120,000 Years.” Water Resources Research. Vol. 32, No. 6, pp. 1,481-1,500.

Tyler, S. W., J. Chapman, and C. Cooper, 1999. Estimates of Evaporation at the Area 5 Radioactive Waste Management Site, Nevada Test Site: Evaluation of Estimates Based on Stable Isotopes and Comparisons to Other Methods. DOE/NV/11508--46. Desert Research Institute, Publication No. 45169. Las Vegas, NV.

U.S. Department of Energy, 1993. DOE O 5400.5, "Radiation Protection of the Public and the Environment.” Washington, D.C.

U.S. Department of Energy, 1999a. DOE O 435.1, “Radioactive Waste Management.” Washington, D.C.

U.S. Department of Energy, 1999b. DOE M 435.1-1, "Radioactive Waste Management Manual.” Washington, D.C.

U.S. Department of Energy, 2004. DOE Standard Guide of Good Practices for Occupational Radiological Protection in Uranium Facilities. DOE-STD-1136-2004. Washington, D.C.

U.S. Department of Energy, National Nuclear Security Administration Nevada Site Office, 2004. NV/YMP RadCon Manual. DOE/NV/11718-079 Rev. 5. Las Vegas, NV. 
U.S. Environmental Protection Agency, 2006. Guidance on Systematic Planning Using the Data Quality Objectives Process. EPA QA/G-4. Washington, D.C.

Walvoord, M.A., F. M. Phillips, S. W. Tyler, and P. C. Hartsough, 2002a. “Deep Arid System Hydrodynamics 2. Application to Paleohydrologic Reconstruction Using Vadose Zone Profiles from the Northern Mojave Desert.” Water Resources Research. Vol. 38, No. 12, pp. 1,291.

Walvoord, M. A., M. A. Plummer, F. M. Phillips, and A. V. Wolfsberg, 2002b. “Deep Arid System Hydrodynamics 1. Equilibrium States and Response Times in Thick Desert Vadose Zones.” Water Resources Research. Vol. 38, No. 12, pp. 1,308.

Wolfsberg, A., and P. Stauffer, 2003. Vadose-zone Fluid and Solute Flux: Advection and Diffusion at the Area 5 Radioactive Waste Management Site. LA-UR-03-4819. Los Alamos National Laboratory. Los Alamos, NM. 
92-Acre Area and CAU 111

Closure Report

Section: Appendix B

Revision: 0

Date: February 2012

\section{APPENDIX B}

\section{AS-BUILT DOCUMENTATION AND CLOSURE CERTIFICATION}


92-Acre Area and CAU 111

Closure Report

Section: Appendix B

Revision: 0

Date: February 2012

THIS PAGE INTENTIONALLY LEFT BLANK 


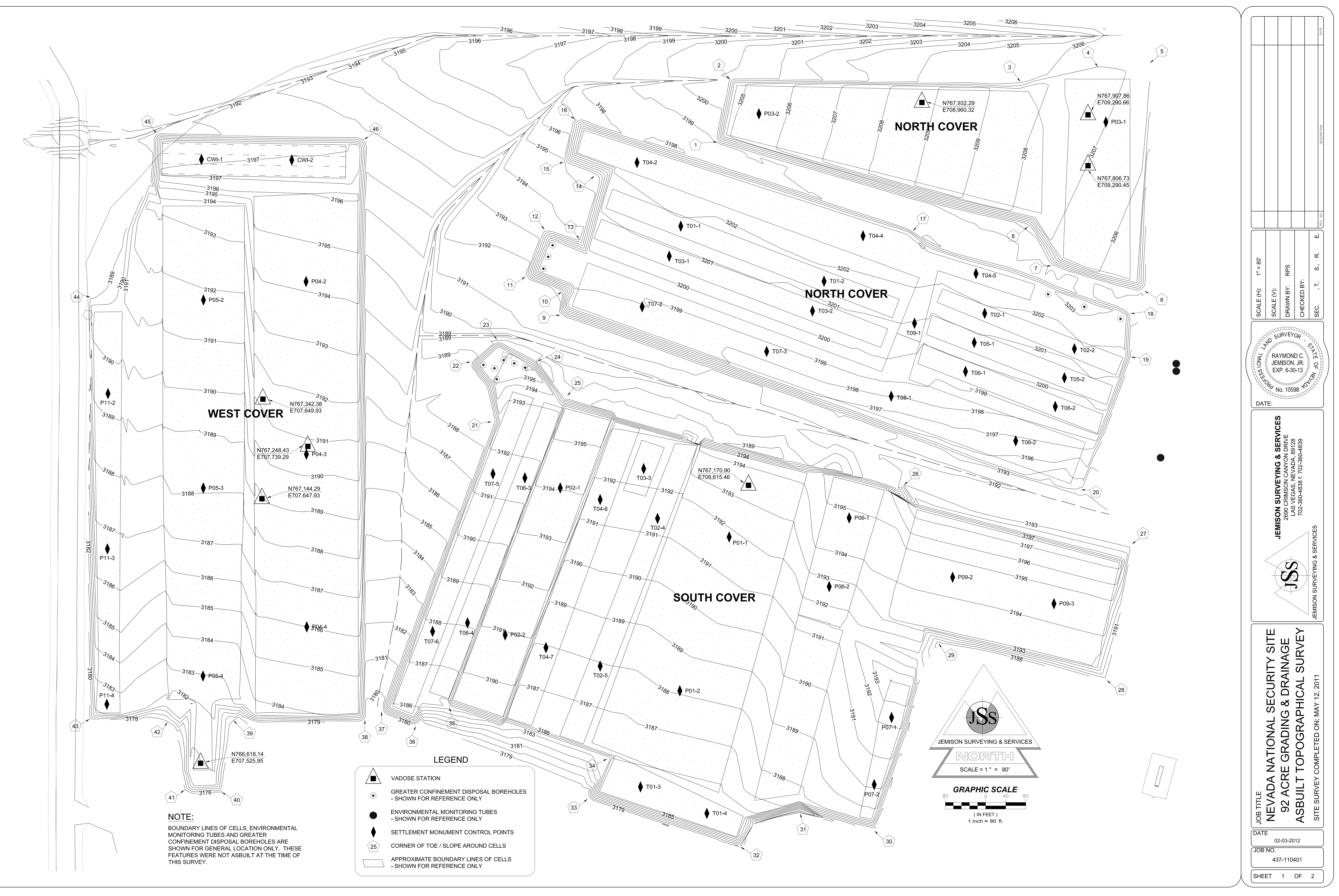




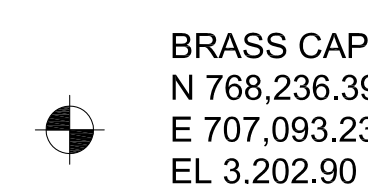

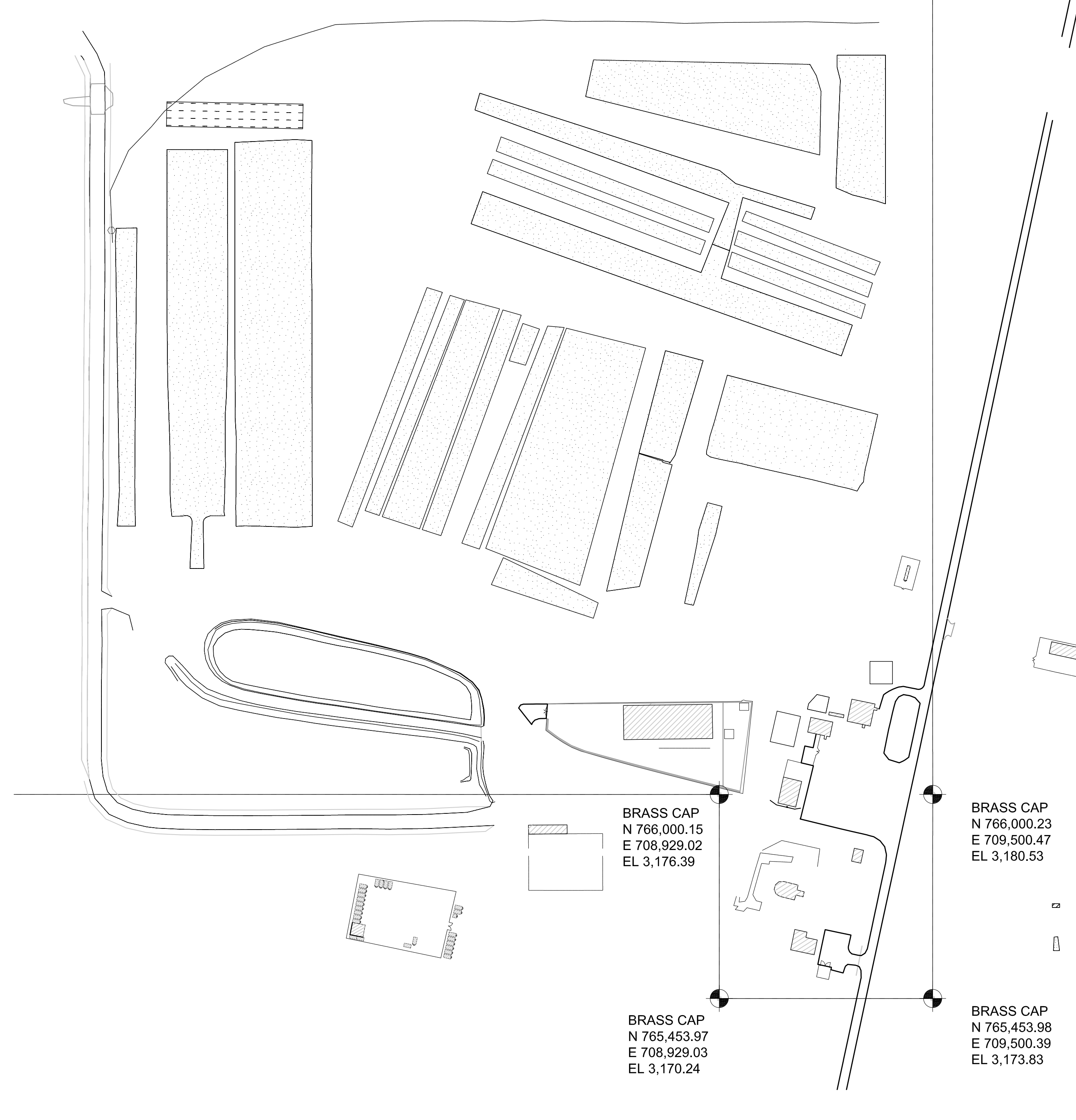

SITE CONTROL
SETTLEMENT MONUMENT CONTROL POINTS

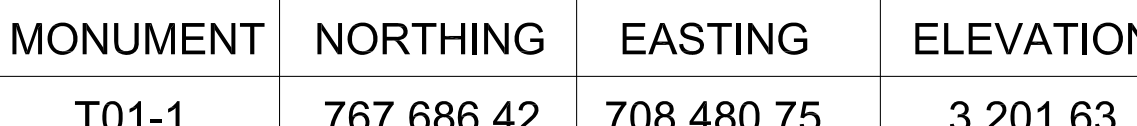

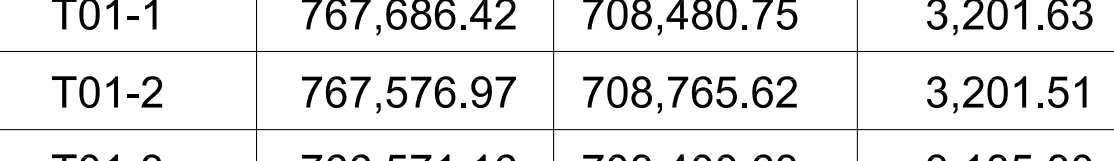

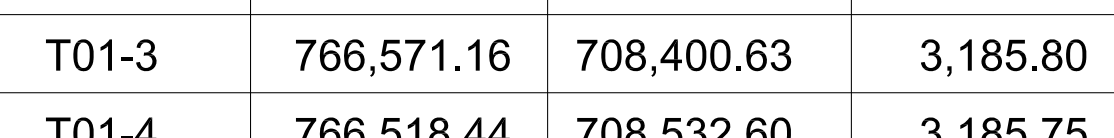

\begin{tabular}{|c|c|c|c|}
\hline To1-4 & $766,518.44$ & $708,532.60$ & 3.185 .75 \\
\hline To2.1 & 7675.51300 & 70902502 & 320161 \\
\hline
\end{tabular}

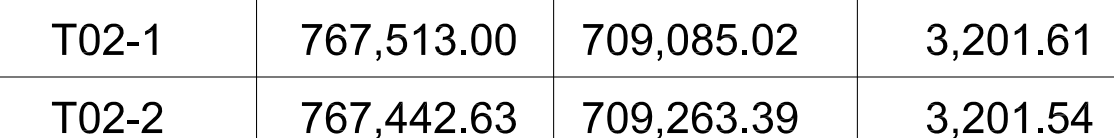

\begin{tabular}{l|l|l|l}
\hline To2-4 & $767,105.13$ & $708,434.57$ & $3,191.59$ \\
\hline
\end{tabular}

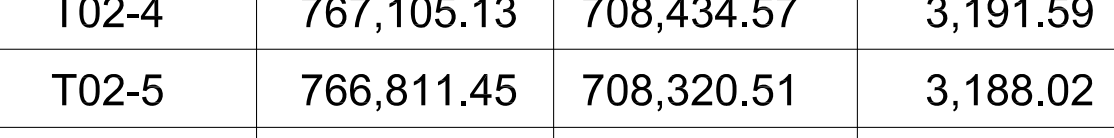

\begin{tabular}{lllll} 
T03-1 & $767,626.67$ & $708,457.81$ & $3,200.69$ \\
\hline
\end{tabular}

\begin{tabular}{cccc} 
To3-2 & $767,517.69$ & $708,742.63$ & $3,200.64$ \\
\hline T03-3 & $767,204.12$ & $708,406.99$ & $3,192.59$ \\
\hline
\end{tabular}

\begin{tabular}{|c|c|c|c|}
\hline To4-2 & $767,813.04$ & $708,393.74$ & $3,202.74$ \\
\hline
\end{tabular}

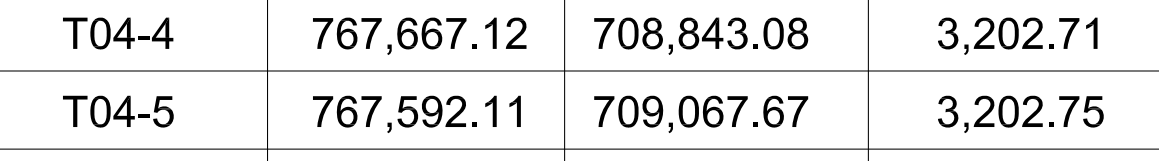

\begin{tabular}{l|lll|}
\hline To4-6 & $767,142.63$ & $708,320.41$ & $3,191.69$ \\
\hline
\end{tabular}

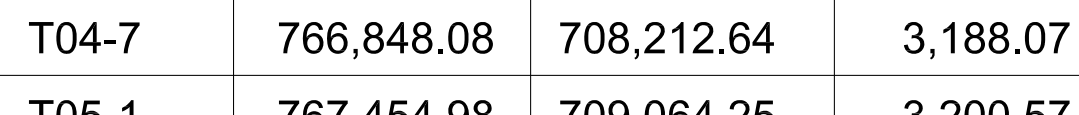

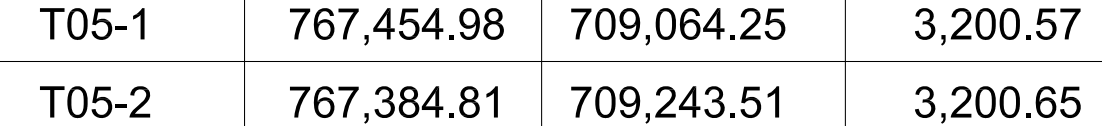

\begin{tabular}{l|l|l|l|}
\hline To6-1 & $767,397,44$ & $709,04046.87$ & $3,1909.65$ \\
\hline
\end{tabular}

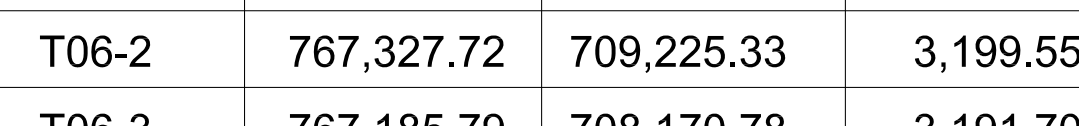

\begin{tabular}{lllll}
\hline To6-3 & $767,185.79$ & $708,170.78$ & $3,191.70$ \\
\hline To6-4 & $766,897.42$ & $708,056.75$ & $3,188.24$ \\
\hline
\end{tabular}

\begin{tabular}{c|c|c|c|}
\hline To7-2 & $767,526.10$ & $708,403.89$ & $3,199.40$ \\
\hline
\end{tabular}

\begin{tabular}{lllll}
\hline To7-3 & $767,437.23$ & $708,651.49$ & $3,199.31$ \\
\hline To7-5 & 76719379 & 708,10732 & $3,191.65$ \\
\hline
\end{tabular}

\begin{tabular}{l|lll|l} 
To7-5 & $767,193.79$ & $708,107.32$ & $3,191.65$ \\
\hline To7-6 & $766,880.36$ & $707, .987 .27$ & $3,187.82$ \\
\hline
\end{tabular}

\begin{tabular}{c|c|c|c|}
\hline To8-1 & $7067,348.16$ & $708,899.13$ & $3,198.06$ \\
\hline
\end{tabular}

\begin{tabular}{|c|c|c|c|}
\hline To8-2 & $767,259.36$ & $709,146.66$ & $3,196.71$ \\
\hline
\end{tabular}

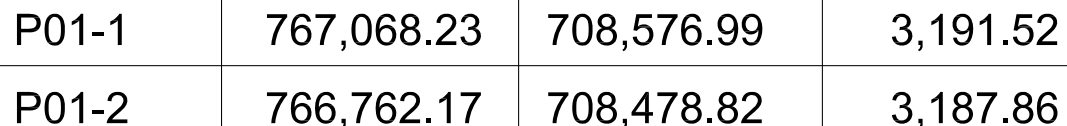

\begin{tabular}{lllll}
\hline & $701-1$ & $766,702.1$ & $708,478.82$ & $3,187.86$ \\
\hline P02-1 & $767,165.74$ & $708,241.09$ & $3,194.13$ \\
\hline
\end{tabular}

\begin{tabular}{lllll}
\hline P02-2 & $766,873.36$ & $708,131.55$ & $3,191.11$ \\
\hline
\end{tabular}

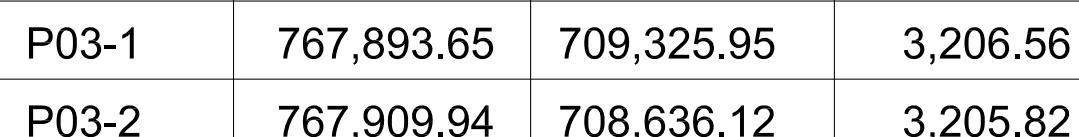

\begin{tabular}{l|l|l|l|l|}
\hline P04-2 & 7675756.26 & 707.735 .61 & 3.19430 \\
\hline
\end{tabular}

\begin{tabular}{llllll} 
P04-3 & $767,232.76$ & $707,736.41$ & $3,190.20$ \\
\hline
\end{tabular}

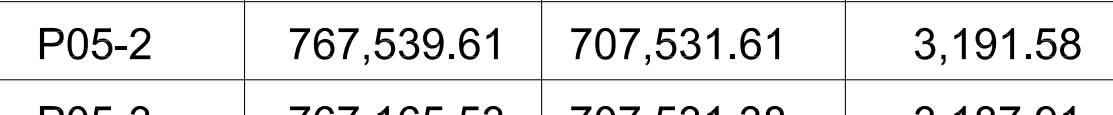

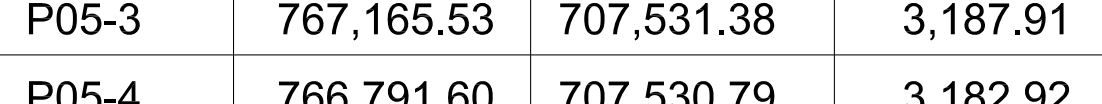

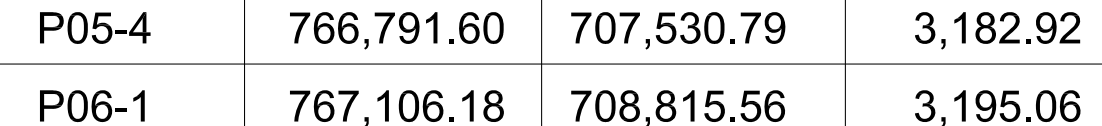

\begin{tabular}{|c|c|c|c|}
\hline P06-2 & $766,969.53$ & $708,775.88$ & $3,195.06$ \\
\hline
\end{tabular}

\begin{tabular}{|l|lll|}
\hline POT-1 & $766,709.20$ & $708,899.85$ & $3,192.37$ \\
\hline
\end{tabular}

\begin{tabular}{lllll}
\hline P07-2 & $766,575.76$ & $708,865.32$ & $3,190.26$ \\
\hline
\end{tabular}

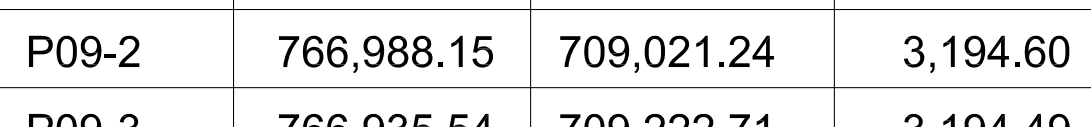

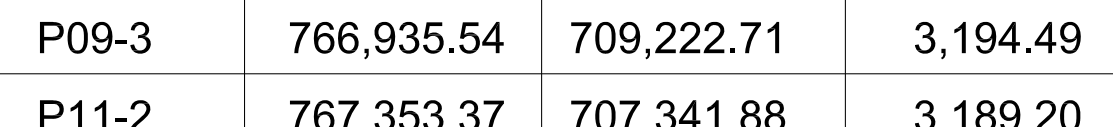

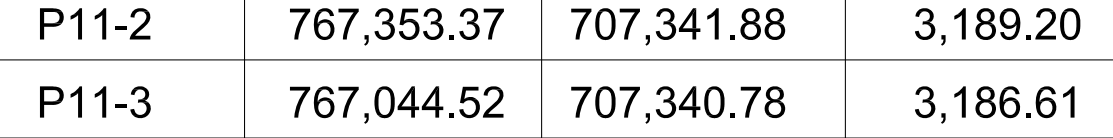

\begin{tabular}{|l|l|l|l|}
\hline$P 11.4$ & $766,735.52$ & $707,339.65$ & $3,182.18$ \\
\hline
\end{tabular}

\begin{tabular}{l|l|l|l|}
\hline CWI-1 & $767,819.18$ & $707,527.63$ & $3,197.01$ \\
\hline CWI-2 & $767,818.07$ & $707,707.29$ & $3,197.17$ \\
\hline
\end{tabular} \begin{tabular}{lllll}
\hline To9-1 & $767,493.24$ & $708,945.49$ & $3,201.08$ \\
\hline
\end{tabular}

\begin{tabular}{|lllll} 
P04.4 & $766,889.48$ & $707,737.12$ & $3,185.91$ \\
\hline
\end{tabular}

CORNER OF TOE / SLOPE AROUND CELLS

PONT NORTHING EASTING ELEVATION \begin{tabular}{|l|l|l|}
\hline $767,977.98$ & $708,578.23$ & $3,200.97$ \\
\hline
\end{tabular} \begin{tabular}{llll}
$767,973.54$ & $709,156.16$ & $3,205.73$ \\
\hline
\end{tabular} \begin{tabular}{cccc}
$768,002.93$ & $709,310.14$ & $3,207.03$ \\
\hline
\end{tabular} \begin{tabular}{llll}
$768,010.79$ & $709,413.21$ & $3,206.67$ \\
\hline 767.55800 & 709,40227 & 320015 \\
\hline
\end{tabular} \begin{tabular}{l|l|l|l|}
\hline 767,60772 & 709218.15 & 3,20026 \\
\hline 7
\end{tabular}

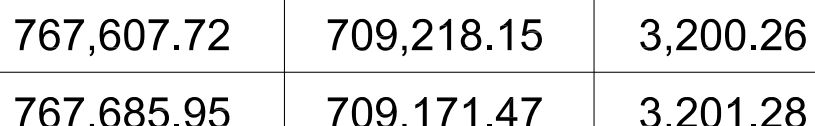
\begin{tabular}{|c|c|c|}
$767,509.68$ & $708,241.86$ & $3,191.63$ \\
\hline
\end{tabular} \begin{tabular}{llll}
$767,556.03$ & $708,244.50$ & $3,192.36$ \\
\hline
\end{tabular} \begin{tabular}{ccc|}
$767,586.20$ & $708,172.58$ & $3,191.74$ \\
\hline
\end{tabular} \begin{tabular}{|l|l|l|}
\hline $767,67.92$ & $700,209.99$ & $3,193.38$ \\
\hline 76760035 & 70827929 & 3,19393 \\
\hline
\end{tabular}

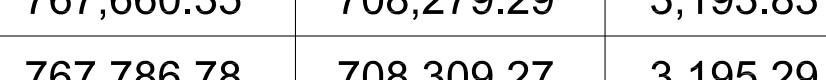
\begin{tabular}{|l|l|l|}
\hline $767,814.86$ & $708,248.09$ & $3,194.92$ \\
\hline
\end{tabular} \begin{tabular}{|l|l|l|}
\hline $767,899.32$ & $708,270.47$ & $3,197.02$ \\
\hline
\end{tabular} \begin{tabular}{|lll|}
$7767,676.33$ & $708,942.35$ & $3,199.29$ \\
\hline
\end{tabular} \begin{tabular}{lll}
$767,512.08$ & $709,374.27$ & $3,199.21$ \\
\hline 777,25 & 709.52 & 3.90029
\end{tabular}

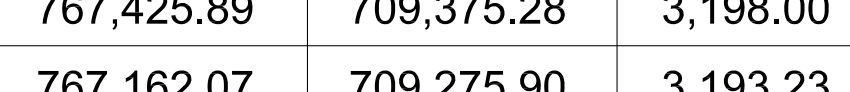
\begin{tabular}{|l|l|l|}
\hline $767,162.07$ & $709,275.90$ & $3,193.23$ \\
\hline 76729754 & 708,10495 & 3,18902 \\
\hline
\end{tabular}

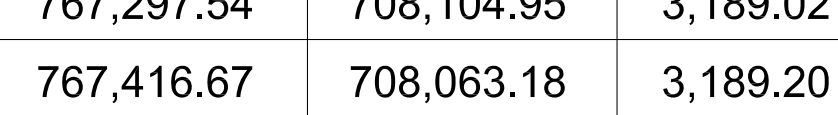
\begin{tabular}{llll}
$767,460.23$ & $708,115.72$ & $3,189.96$ \\
\hline
\end{tabular} \begin{tabular}{lll}
$7667,417.50$ & $708,195.19$ & $3,190.75$ \\
\hline
\end{tabular} \begin{tabular}{|l|l|l|}
$7767,348.54$ & $708,255.08$ & $3,190.23$ \\
\hline 787,179 & 700240 \\
\hline
\end{tabular}

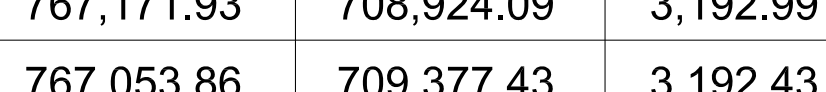
\begin{tabular}{|l|l|l|l|}
\hline $767,053.86$ & $709,377.43$ & $3,192.43$ \\
\hline $766,783.53$ & $709,327.72$ & $3,189.38$ \\
\hline 7
\end{tabular} \begin{tabular}{l|l|l}
$766,856.49$ & $708,993.33$ & $3,187.51$ \\
\hline
\end{tabular} \begin{tabular}{lll}
$766,484.20$ & $708,865.63$ & $3,183.83$ \\
\hline
\end{tabular}

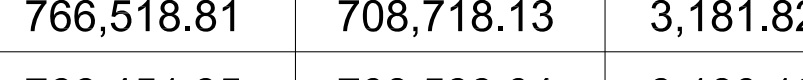

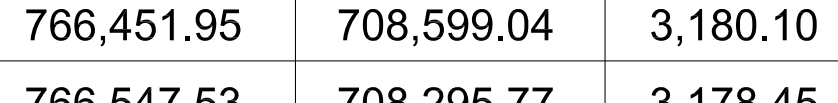
\begin{tabular}{|l|l|l|l|}
\hline 7666,62737 & $708,334.86$ & $3,183.76$ \\
\hline
\end{tabular} \begin{tabular}{|c|c|c|}
\hline $760,729.42$ & $700,03020.59$ & $3,18.185 .56$ \\
\hline
\end{tabular} \begin{tabular}{|c|c|c|}
$766,692.10$ & $707,954.11$ & $3,179.53$ \\
\hline
\end{tabular} \begin{tabular}{llll}
$766,721.22$ & $707,885.90$ & $3,179.43$ \\
\hline
\end{tabular} \begin{tabular}{lll}
$7666,704.61$ & $707,852.82$ & $3,180.21$ \\
\hline 700672 & &
\end{tabular}

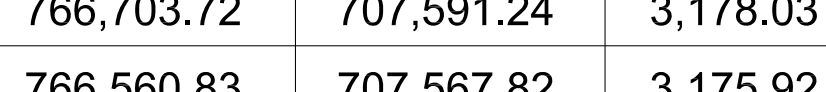
\begin{tabular}{|l|l|l|}
\hline $766,560.83$ & $707,567.82$ & $3,175.92$ \\
\hline 76655504 & 707,49435 & 3.17580 \\
\hline
\end{tabular} \begin{tabular}{|l|l|l|l|}
$7606,700.59$ & $707,459.96$ & 3.177790 \\
\hline
\end{tabular} \begin{tabular}{|l|l|l|}
\hline $766,706.28$ & $707,305.88$ & $3,178.70$ \\
\hline
\end{tabular}

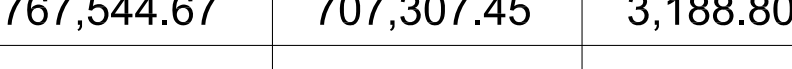

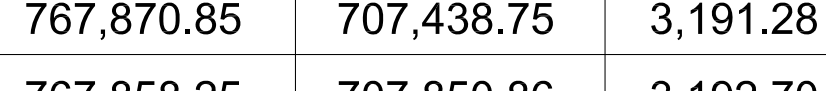

DASED ON CAD FLEE (09068-005-CS-SITE-MODE)

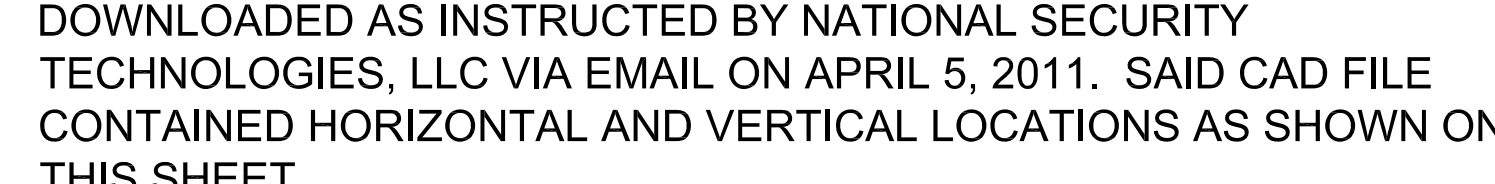
BASIS FOR HORZZONTAL CONTROL: NORTH AMERICAN DATUM 1927. AASIS FOR VERTICAL CONTROL: NORTH AMERICAN VERTICAL DATUM

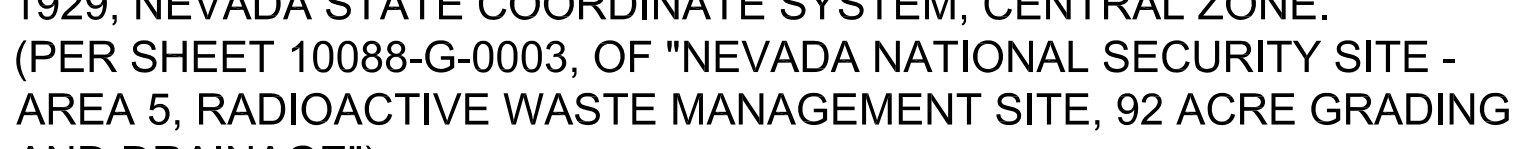




\subsection{CONCLUSION AND FINAL CERTIFICATION}

J. A. Cesare and Associates, Inc. provided Construction Quality Assurance services during construction for the 92 Acre Area Evapotranspiration Cover Project at the Area 5 Radioactive Waste Management Complex within the Nevada National Security Site (NNSS). These services were provided in a manner that is consistent with current standards of practice and the degree of care and skill ordinarily exercised under similar conditions by reputable members of the same profession in similar localities. The conclusions presented in this Final Construction Acceptance Report are based upon observations made by J. A. Cesare and Associates representatives at selected locations and times during the 92 Acre Evapotranspiration Cover construction.

The signature and seal provided below is a declaration by the CQA Engineer that, in his professional judgement, the subject project was constructed in a manner consistent with the approved Construction Quality Assurance Program and referenced design documents, specifications, and drawings.

This Final Construction Acceptance report was prepared under the CQA Engineer's direction and supervision in accordance with a system designed to assure that qualified personnel properly gather and evaluate the information submitted. The information submitted is, to the best of the Professional Engineer's knowledge and belief to be true and accurate.

\section{J. A. Cesare and Associates, Inc.}

By:

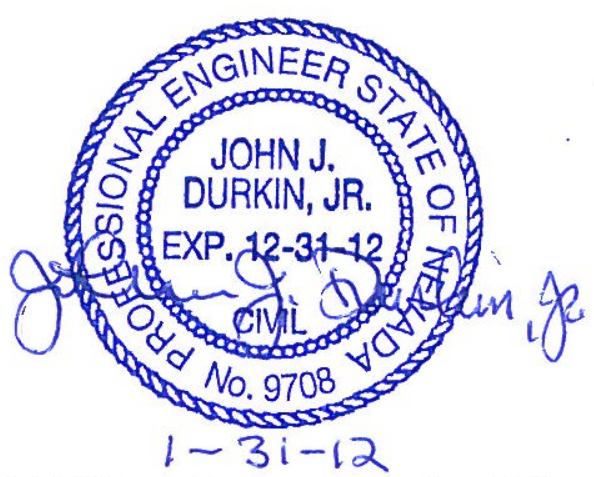

John J. Durkin, Jr., P.E.

CQA Engineer 
92-Acre Area and CAU 111

Closure Report

Section: Appendix B

Revision: 0

Date: February 2012

THIS PAGE INTENTIONALLY LEFT BLANK 
92-Acre Area and CAU 111

Closure Report

Section: Appendix C

Revision: 0

Date: February 2012

\section{APPENDIX C}

\section{USE RESTRICTION DOCUMENTATION}


92-Acre Area and CAU 111

Closure Report

Section: Appendix C

Revision: 0

Date: February 2012

THIS PAGE INTENTIONALLY LEFT BLANK 


\section{Use Restriction Information}

CAU Number/Description: CAU 111/Area 5 WMD Retired Mixed Waste Pits

Applicable CAS Number/Description: CAS 05-21-01/Mixed Waste Pits

Contact (Federal Sub-Project Director/Sub-Project): Jhon T. Carilli/LLW

FFACO Use Restriction Physical Description:

Surveyed Areas (UTM, Zone 11, NAD 83, meters):

\begin{tabular}{|c|c|c|}
\hline \hline \multicolumn{3}{|c|}{ WEST COVER } \\
\hline \hline UR Points & Northing & Easting \\
\hline W1 & $4,079,214.431$ & $592,972.327$ \\
\hline W2 & $4,079,213.881$ & $592,892.618$ \\
\hline W3 & $4,079,170.313$ & $592,885.633$ \\
\hline W4 & $4,079,171.518$ & $592,863.240$ \\
\hline W5 & $4,079,212.787$ & $592,852.617$ \\
\hline W6 & $4,079,214.357$ & $592,805.658$ \\
\hline W7 & $4,079,469.842$ & $592,805.246$ \\
\hline W9 & $4,079,569.379$ & $592,844.909$ \\
\hline
\end{tabular}

\begin{tabular}{|c|c|c|}
\hline \multicolumn{3}{|c|}{ NORTH COVER } \\
\hline \hline UR Points & Northing & Easting \\
\hline N1 & $4,079,355.351$ & $593,405.491$ \\
\hline N2 & $4,079,460.175$ & $593,090.022$ \\
\hline N3 & $4,079,483.420$ & $593,068.829$ \\
\hline N & $4,079,578.941$ & $593,098.326$ \\
\hline N6 & $4,079,565.412$ & $593,184.740$ \\
\hline N7 & $4,079,603.239$ & $593,192.025$ \\
\hline N8 & $4,079,614.128$ & $593,446.431$ \\
\hline N9 & $4,079,476.137$ & $593,443.578$ \\
\hline
\end{tabular}

\begin{tabular}{|c|c|c|}
\hline \multicolumn{3}{|c|}{ SOUTH COVER } \\
\hline \hline UR Points & Northing & Easting \\
\hline S1 & $4,079,148.345$ & $593,281.191$ \\
\hline S2 & $4,079,138.234$ & $593,199.988$ \\
\hline S3 & $4,079,167.036$ & $593,107.472$ \\
\hline S4 & $4,079,219.528$ & $592,982.390$ \\
\hline S5 & $4,079,397.858$ & $593,047.107$ \\
\hline S6 & $4,079,431.642$ & $593,035.672$ \\
\hline S7 8 & $4,079,444.972$ & $593,051.636$ \\
\hline S9 & $4,079,432.036$ & $593,075.898$ \\
\hline S10 & $4,079,411.085$ & $593,094.222$ \\
\hline S11 & $4,079,322.484$ & $593,436.545$ \\
\hline S12 & $4,079,240.053$ & $593,421.684$ \\
\hline
\end{tabular}

Depth: $\underline{0-120 \text { feet below ground surface }}$

Survey Source (GPS, GIS, etc): $\underline{\text { GIS }}$

Basis for FFACO UR(s):

Summary Statement: This use restriction (UR) was implemented to restrict activities that may expose workers to

Note: Effective upon acceptance of closure documents by NDEP

Page 1 of 2 
contamination within the boundaries of the landfill. Hazardous, radioactive, and mixed constituents are present in the waste buried in the landfill.

Contaminants Table:

\begin{tabular}{|c|c|c|c|}
\hline \multicolumn{4}{|c|}{ Maximum Concentration of Contaminants for CAU 111 } \\
CAS 05-21-01, Mixed Waste Pits \\
\hline Constituent & $\begin{array}{c}\text { Maximum } \\
\text { Concentration }\end{array}$ & Action Level & Units \\
\hline NA & NA & NA & NA \\
\hline
\end{tabular}

Site Controls: UR warning signs and concrete monuments

UR Maintenance Requirements:

Description: Certify that postings are in place, intact, and readable. Inspect cover for cracks, animal burrows, or other evidence of subsidence or erosion. Perform annual subsidence surveys and annual evaluation of vegetation. Additional monitoring requirements include direct radiation monitoring, air monitoring, radon flux monitoring. groundwater monitoring, and vadose zone monitoring. The Closure Report includes additional details on the monitoring requirements. This UR must be entered into the DOE/NV Facility Information Management System (FIMS) and the FFACO databases.

Inspection/Maintenance Frequency: Quarterly and if precipitation occurs in excess of 1.0 inch in 24 hours

The future use of any land related to this Corrective Action Unit (CAU), as described by the above surveyed location, is restricted from any DOE or Air Force activity that may alter or modify the containment control as approved by the State and identified in the CAU CR or other CAU documentation unless appropriate concurrence is obtained in advance.

Comments: See the Closure Report for additional information on the condition of the site. Results of the quarterly inspections will be provided in the annual combined post-closure report for closed RCRA CAUs.

Submitted By: /s/: Jhon T. Carilli_Date: $2 / 2 / 2012$ 


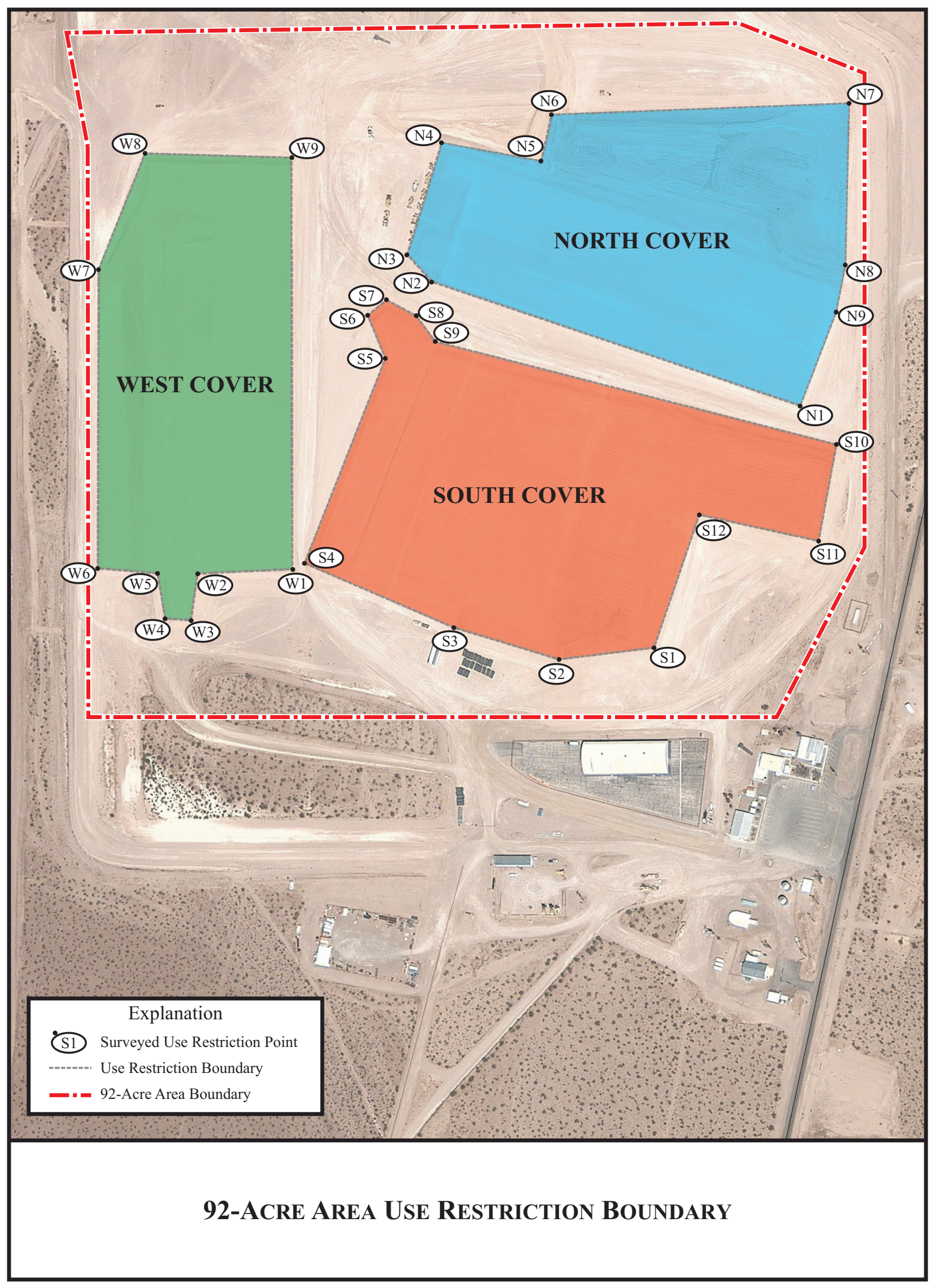


92-Acre Area and CAU 111

Closure Report

Section: Appendix C

Revision: 0

Date: February 2012

THIS PAGE INTENTIONALLY LEFT BLANK 
92-Acre Area and CAU 111

Closure Report

Section: Appendix D

Revision: 0

Date: February 2012

\section{APPENDIX D}

\section{SITE CLOSURE PHOTOGRAPHS}


92-Acre Area and CAU 111

Closure Report

Section: Appendix D

Revision: 0

Date: February 2012

THIS PAGE INTENTIONALLY LEFT BLANK 
Photograph Log

\begin{tabular}{|c|l|l||}
\hline $\begin{array}{c}\text { PHOTOGRAPH } \\
\text { NuMBER }\end{array}$ & DATE & \multicolumn{1}{c|}{ DESCRIPTION } \\
\hline \hline 1 & $02 / 04 / 2011$ & Backfilling P03 \\
\hline 2 & $04 / 04 / 2011$ & Backfilling P06 \\
\hline 3 & $04 / 04 / 2011$ & Loaded Backfill Material for Cover Construction \\
\hline 4 & $04 / 04 / 2011$ & Equipment Used for Ripping the Cover \\
\hline 5 & $04 / 04 / 2011$ & Track Walking the Cover \\
\hline 6 & $05 / 04 / 2011$ & Placing Cover Material \\
\hline 7 & $05 / 04 / 2011$ & Ripping the Cover \\
\hline 8 & $05 / 09 / 2011$ & Placing Riprap in Arizona Crossing \\
\hline 9 & $10 / 20 / 2011$ & Disking the Cover for Seeding \\
\hline 10 & $11 / 03 / 2011$ & Installing Straw Mulch and Crimping \\
\hline 11 & $01 / 03 / 2012$ & Irrigation \\
\hline 12 & $01 / 19 / 2012$ & Installing Subsidence Survey Monument \\
\hline 13 & $01 / 25 / 2012$ & Use Restriction Warning Sign \\
\hline 14 & $01 / 25 / 2012$ & Concrete Monument \\
\hline
\end{tabular}


92-Acre Area and CAU 111

Closure Report

Section: Appendix D

Revision: 0

Date: February 2012

THIS PAGE INTENTIONALLY LEFT BLANK 


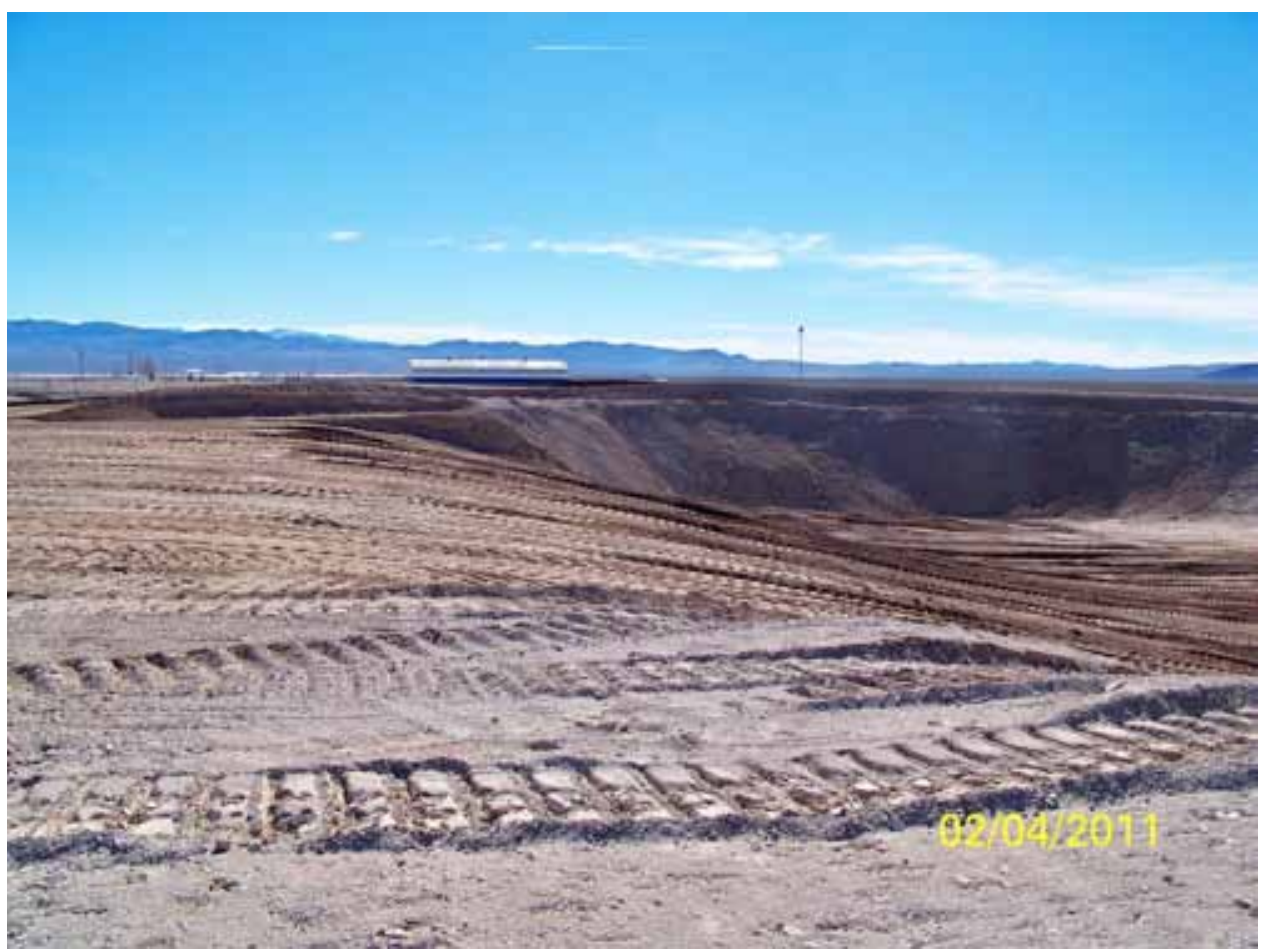

Photograph 1: Backfilling P03, 02/04/2011

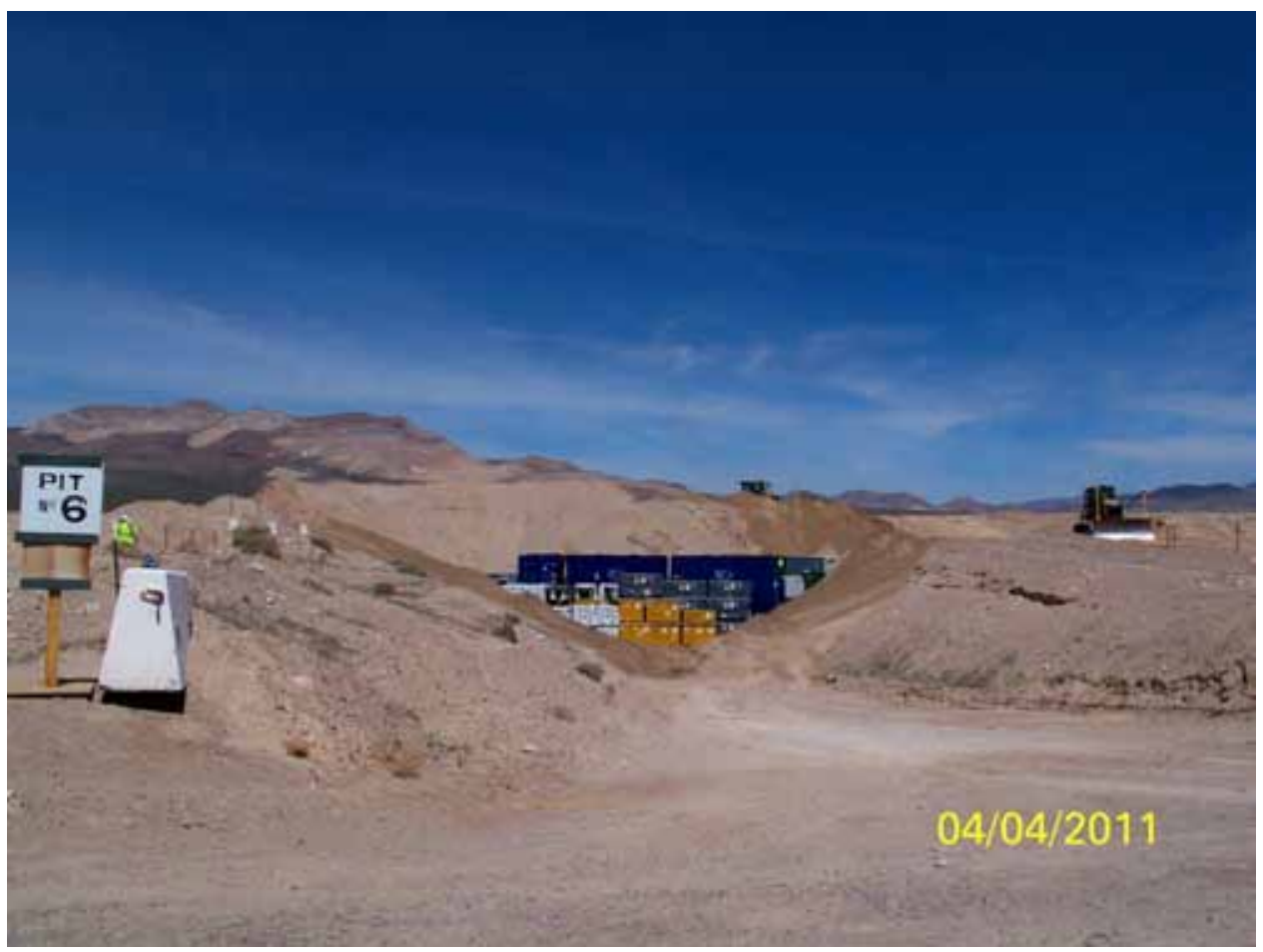

Photograph 2: Backfilling P06, 04/04/2011 


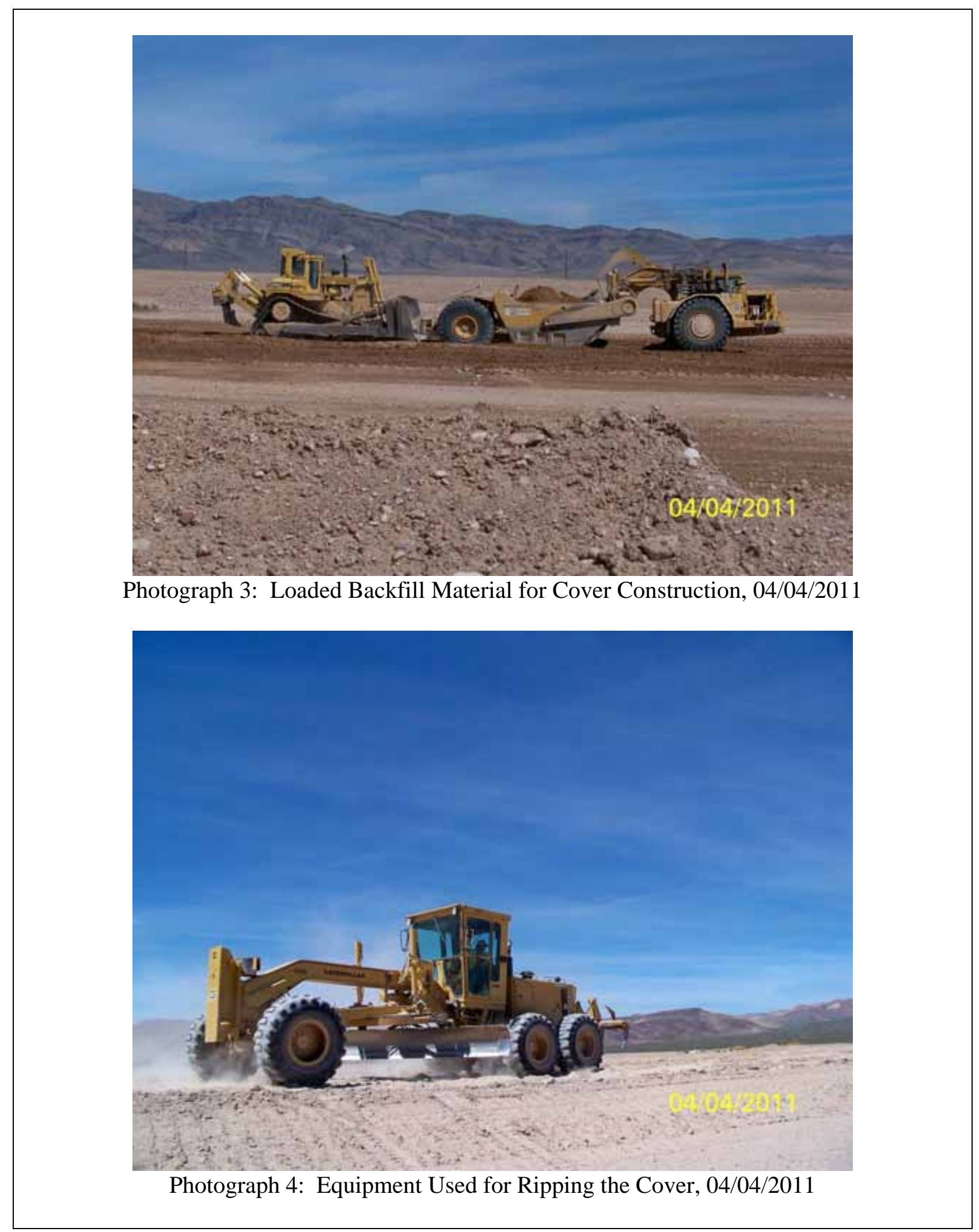




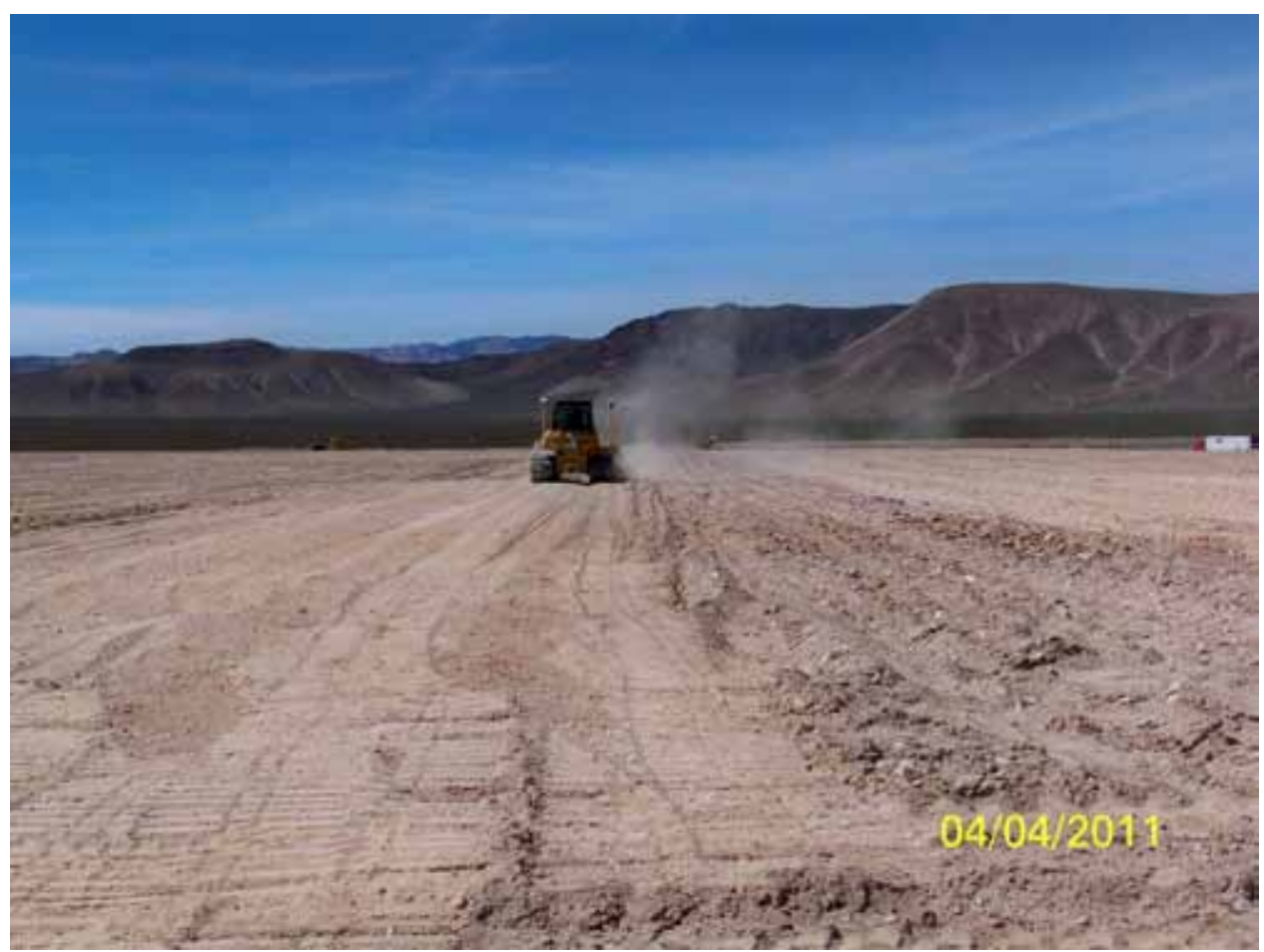

Photograph 5: Track Walking the Cover, 04/04/2011

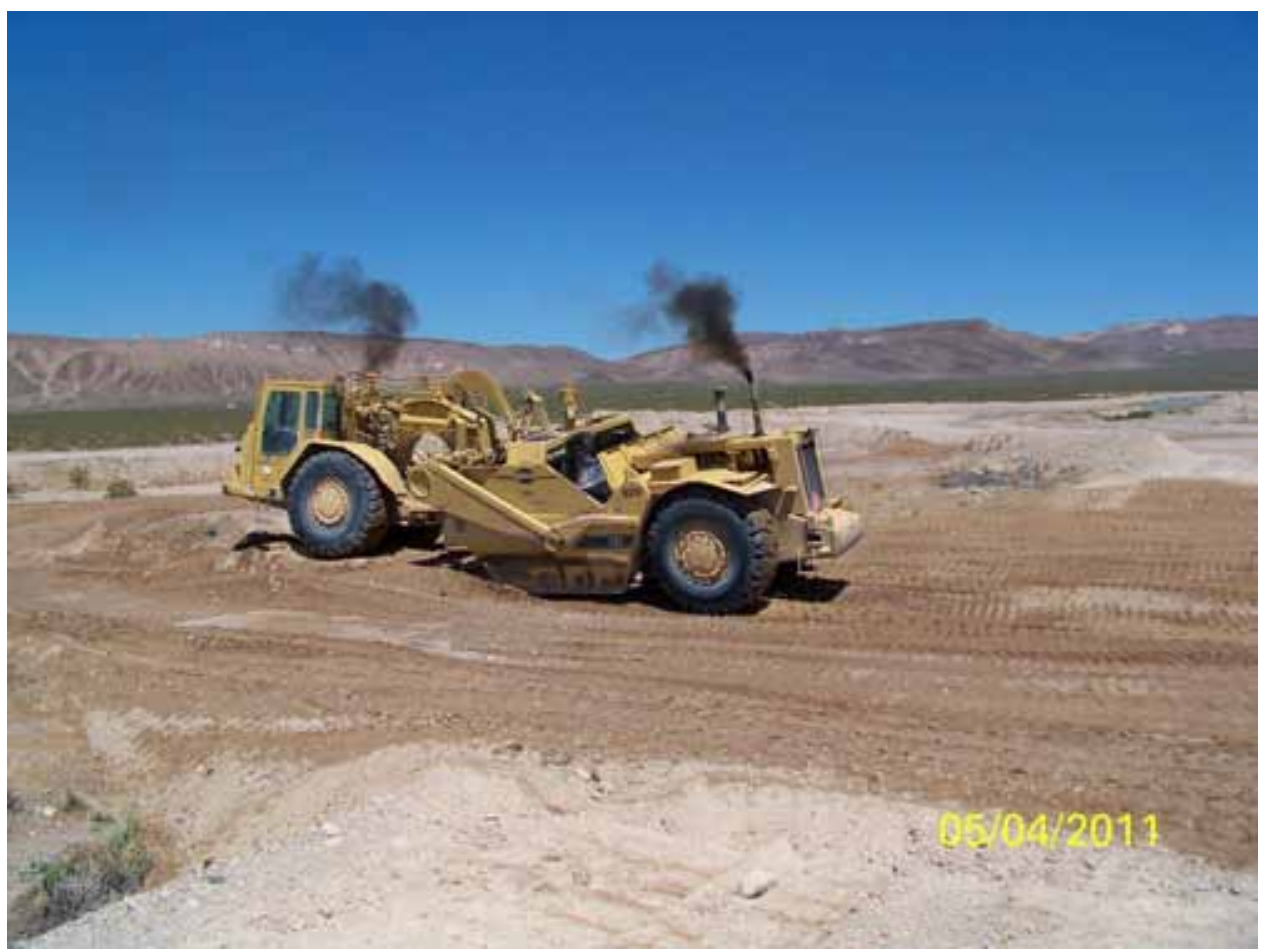

Photograph 6: Placing Cover Material, 05/04/2011 
92-Acre Area and CAU 111

Section: Appendix D

Revision: 0

Date: February 2012

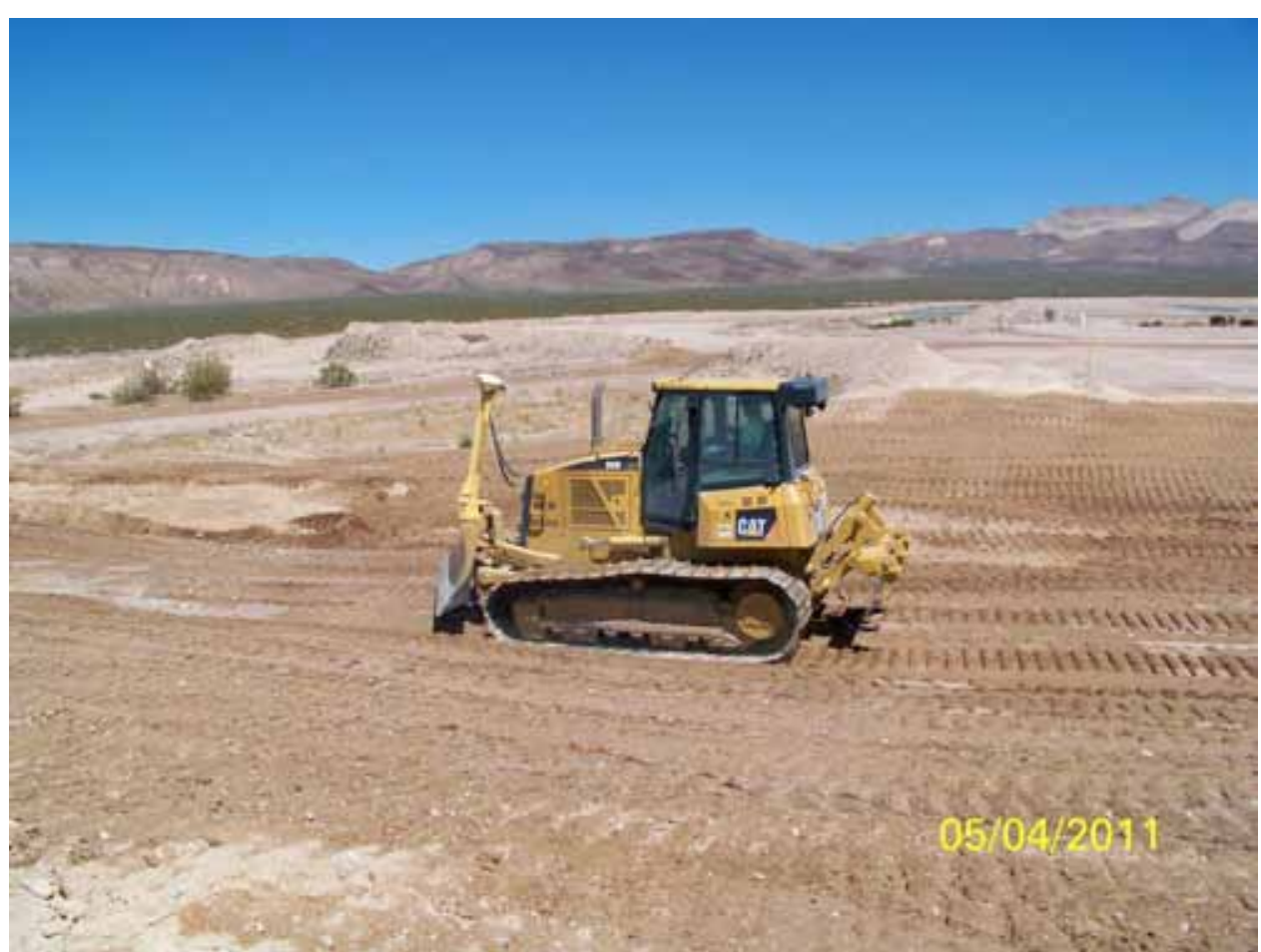

Photograph 7: Ripping the Cover, 05/04/2011

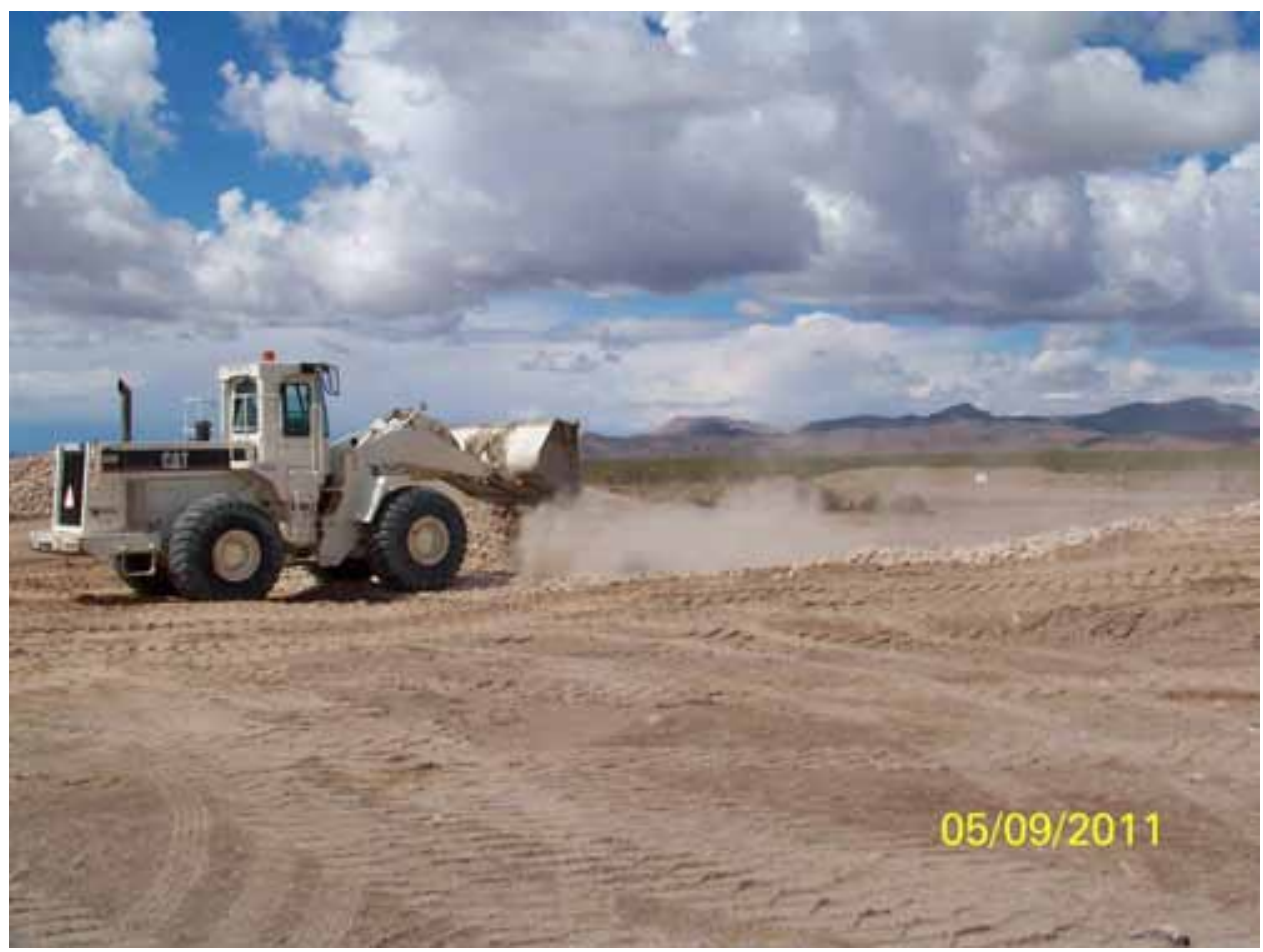

Photograph 8: Placing Riprap in Arizona Crossing, 05/09/2011 


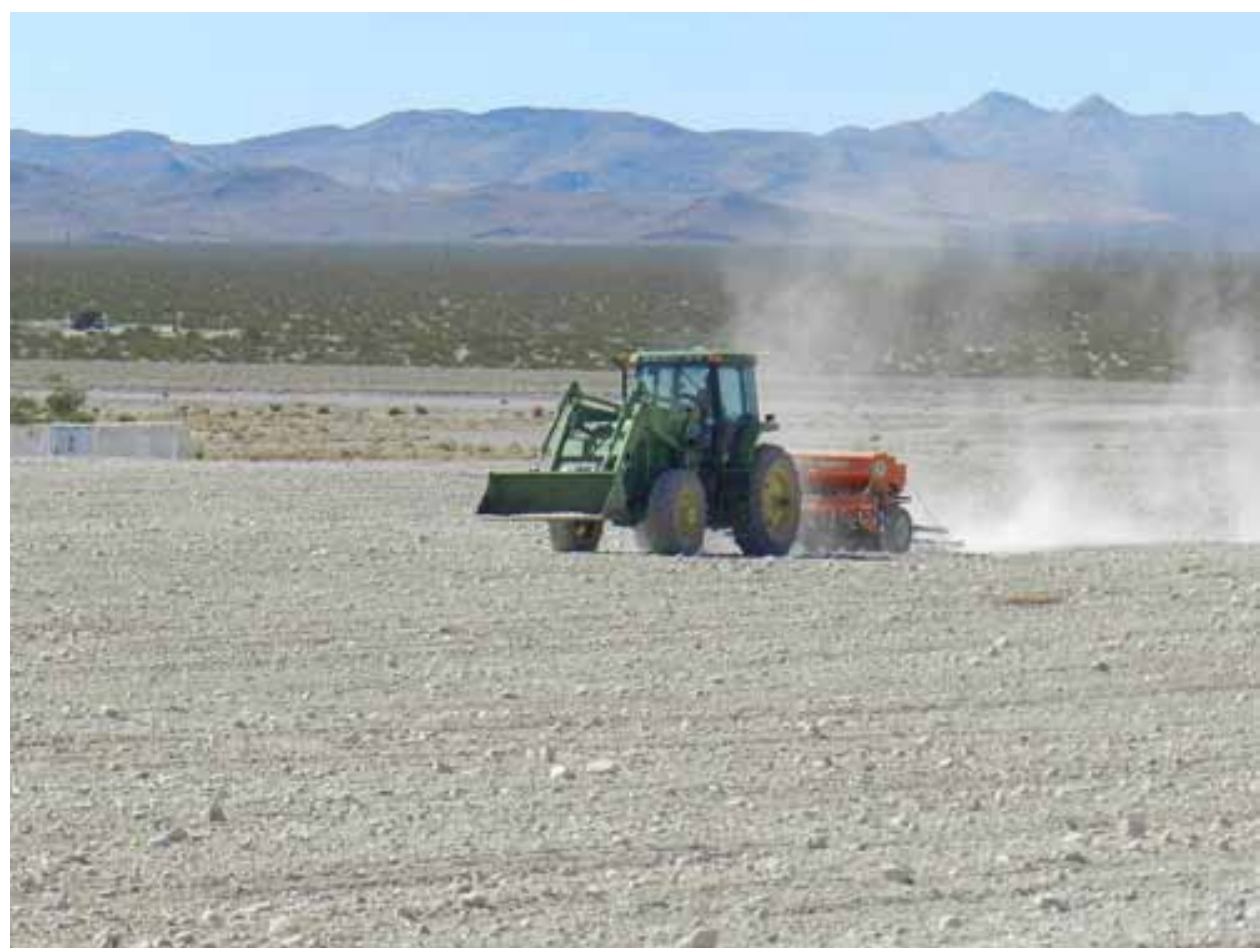

Photograph 9: Disking the Cover for Seeding, 10/20/2011

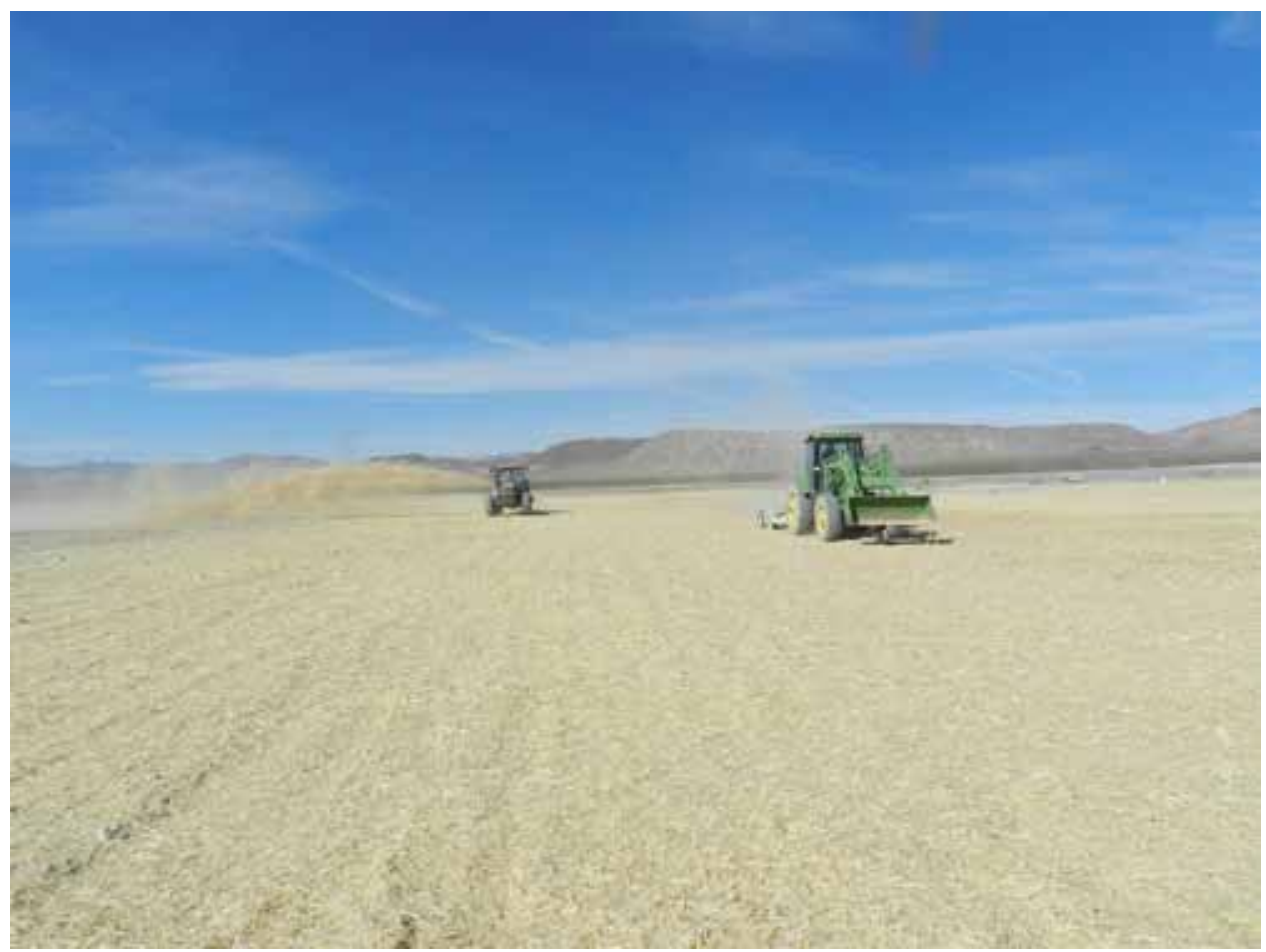

Photograph 10: Installing Straw Mulch and Crimping, 11/03/2011 
92-Acre Area and CAU 111

Closure Report

Section: Appendix D

Revision: 0

Date: February 2012

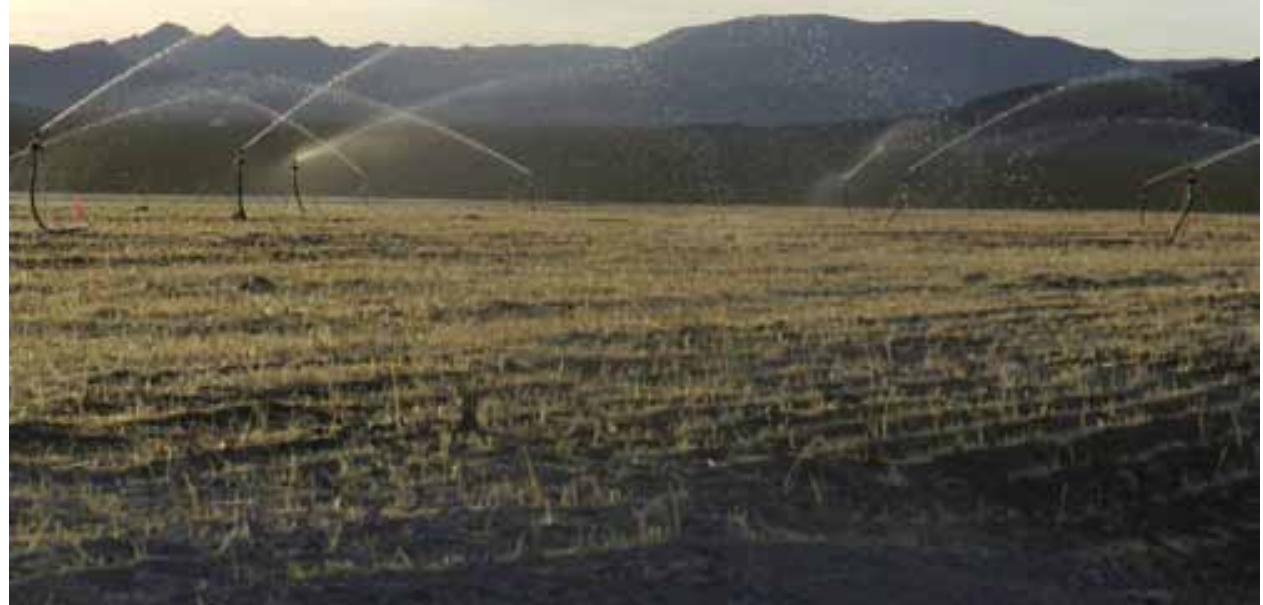

Photograph 11: Irrigation, 01/03/2012

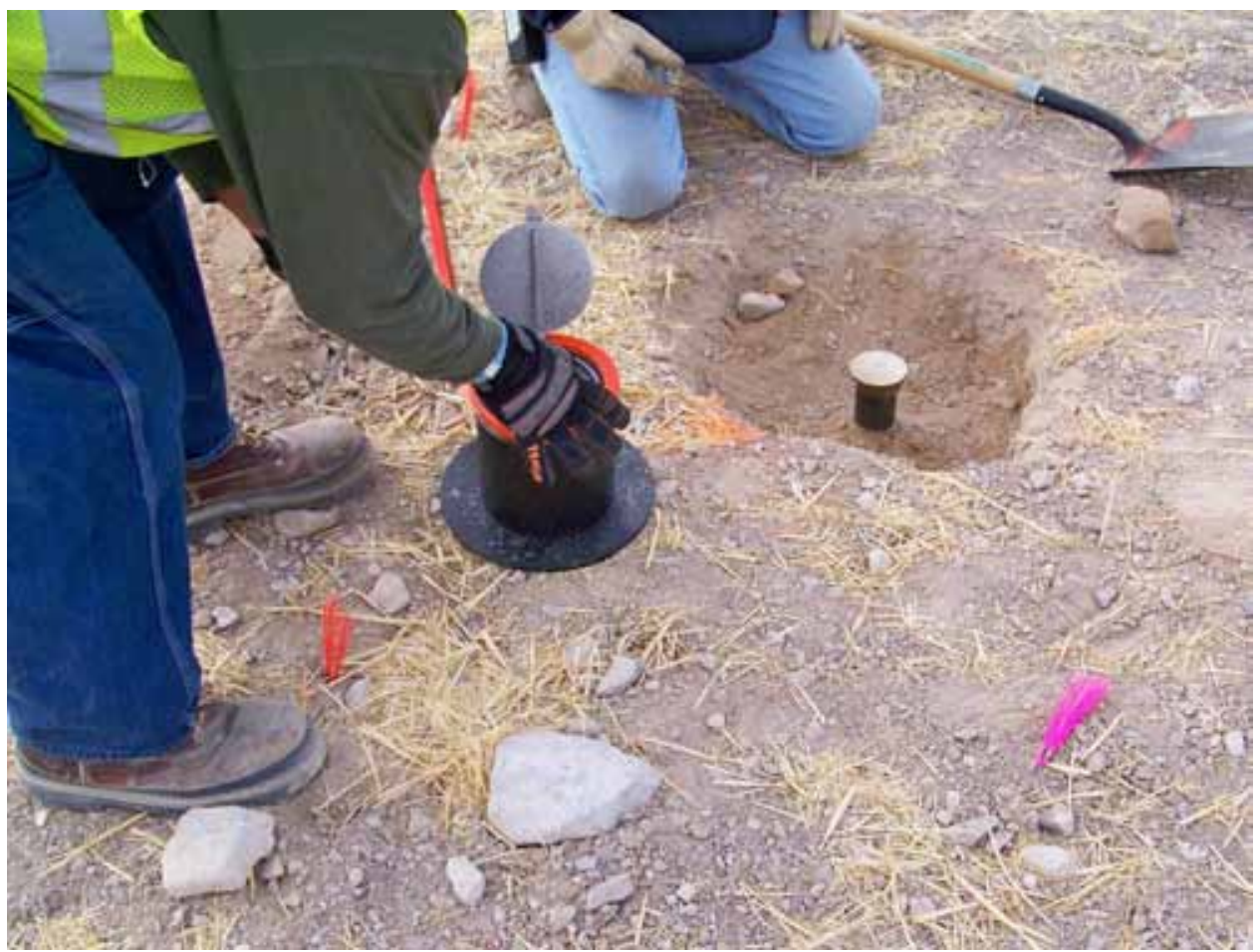

Photograph 12: Installing Subsidence Survey Monument, 01/19/2012 


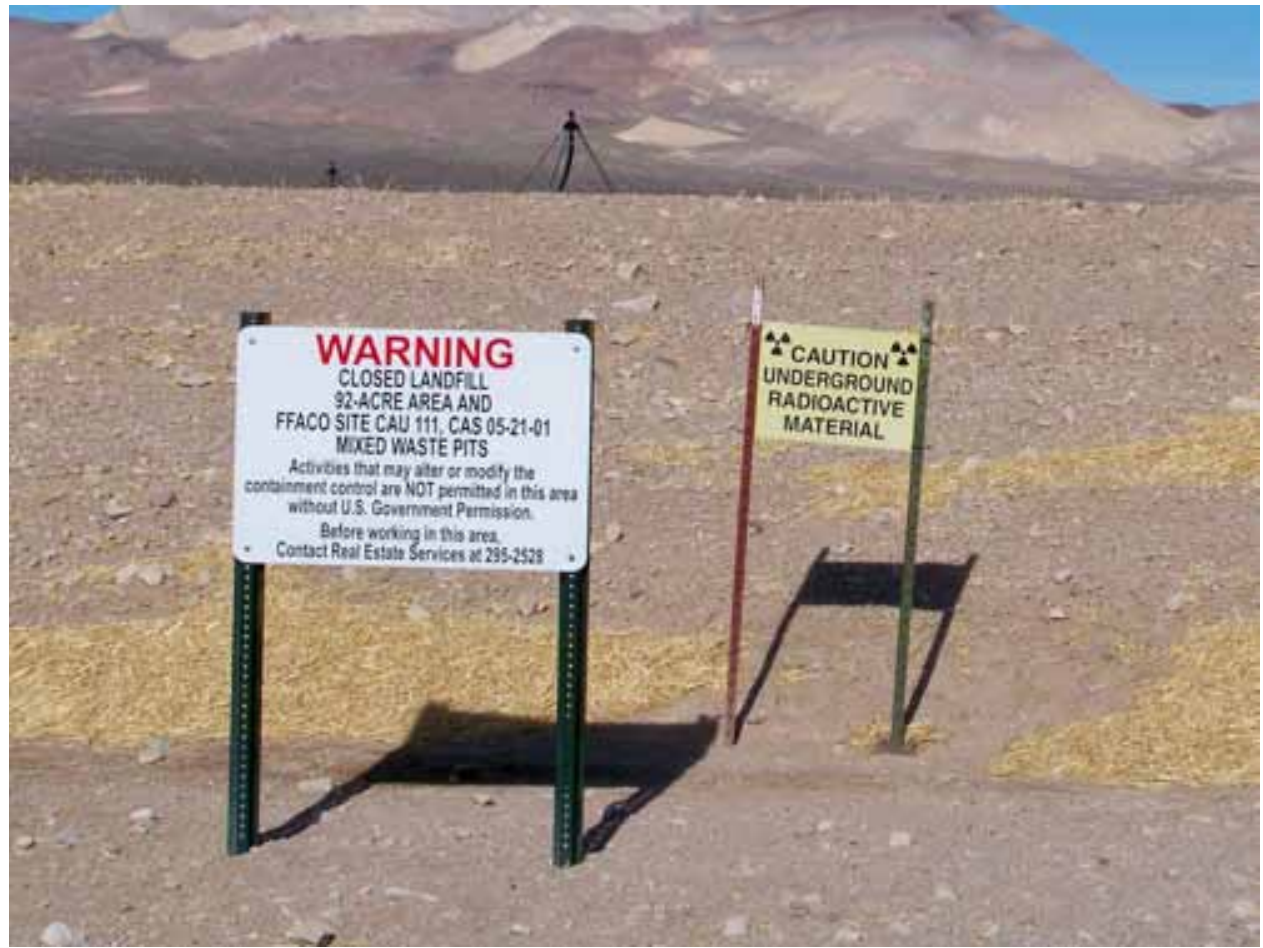

Photograph 13: Use Restriction Warning Sign, 01/25/2012

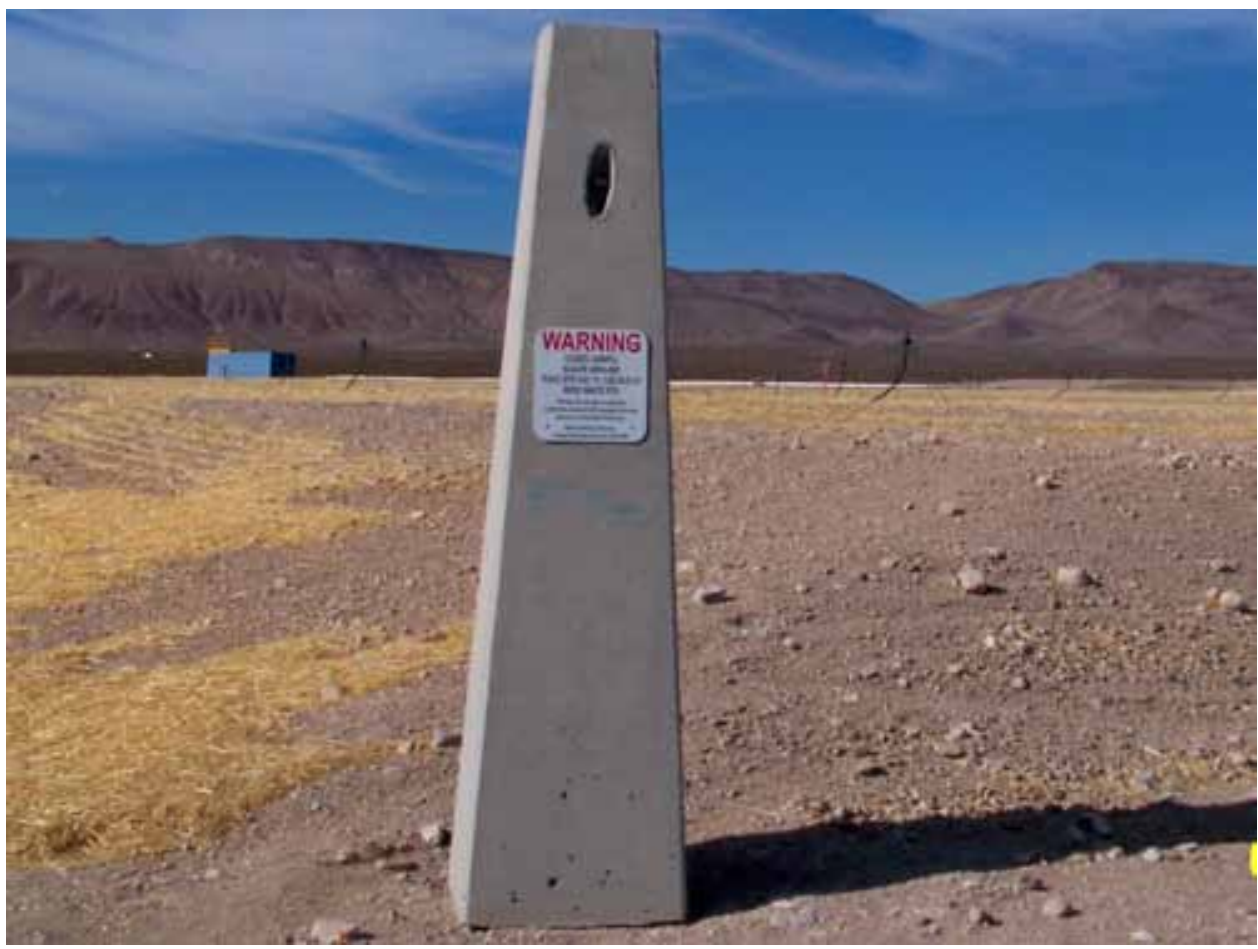

Photograph 14: Concrete Monument, 01/25/2012 
92-Acre Area and CAU 111

Closure Report

Section: Appendix D

Revision: 0

Date: February 2012

THIS PAGE INTENTIONALLY LEFT BLANK 
92-Acre Area and CAU 111

Closure Report

Section: Library Distribution List

Revision: 0

Date: February 2012

\section{LIBRARY DISTRIBUTION LIST}


92-Acre Area and CAU 111

Closure Report

Section: Library Distribution List

Revision: 0

Date: February 2012

THIS PAGE INTENTIONALLY LEFT BLANK 


\section{LIBRARY DISTRIBUTION LIST}

U.S. Department of Energy

National Nuclear Security Administration

Nevada Site Office

Technical Library

P.O. Box 98518, M/S 505

Las Vegas, NV 89193-8518

U.S. Department of Energy

Office of Scientific and Technical Information

P.O. Box 62

Oak Ridge, TN 37831-0062

Southern Nevada Public Reading Facility

c/o Nuclear Testing Archive

P.O. Box 98521, M/S 400

Las Vegas, NV 89193-8521

Manager, Northern Nevada FFACO

Public Reading Facility

c/o Nevada State Library \& Archives

Carson City, NV 89701-4285
1 (Uncontrolled, electronic copy)

1 (Uncontrolled, electronic copy)

2 (Uncontrolled, electronic copies)

1 (Uncontrolled, electronic copy) 
92-Acre Area and CAU 111

Closure Report

Section: Library Distribution List

Revision: 0

Date: February 2012

THIS PAGE INTENTIONALLY LEFT BLANK 